\author{
UNIVERSIDADE DE SÃO PAULO \\ ESCOLA DE ARTES, CIÊNCIAS E HUMANIDADES \\ PROGRAMA DE PÓS-GRADUAÇÃO EM MUDANÇA SOCIAL E \\ PARTICIPAÇÃO POLÍTICA
}

ANA PAULA ROSA RODRIGUES

As transformações do universo museal pelos paradigmas do conhecimento e o aprimoramento de sua função social a partir da Nova Museologia

São Paulo 


\section{As transformações do universo museal pelos paradigmas do conhecimento e o aprimoramento de sua função social a partir da Nova Museologia}

\section{Versão corrigida}

Dissertação apresentada à Escola de Artes, Ciências e Humanidades da Universidade de São Paulo para a obtenção do Título de Mestre em Ciências pelo Programa de Pós-Graduação em Mudança Social e Participação Política.

Área de Concentração: Mudança Social e Participação Política

Orientador: Professor Dr. Edegar Luis Tomazzoni

Versão corrigida contendo as alterações solicitadas pela comissão julgadora em 05/06/2019. A versão original encontra-se em acervo reservado na biblioteca da EACH-USP e na biblioteca digital de teses e dissertações da USP (BDTD), de acordo com a resolução CoPGr 6018, de 13 de outubro de 2011.

São Paulo 
Autorizo a reprodução e divulgação total ou parcial deste trabalho, por qualquer meio convencional ou eletrônico, para fins de estudo e pesquisa, desde que citada a fonte.

CATALOGAÇÃO-NA-PUBLICAÇÃO

(Universidade de São Paulo. Escola de Artes, Ciências e Humanidades. Biblioteca) CRB 8 - 4936

Rodrigues, Ana Paula Rosa

As transformaçőes do universo museal pelos paradigmas do

conhecimento e o aprimoramento de sua funçáo social a partir da Nova

Museologia / Ana Paula Rosa Rodrigues ; orientador, Edegar Luis

Tomazzoni. - 2018

155 f.: il.

Dissertação (Mestrado em Ciências) - Programa de PósGraduaçāo em Mudança Social e Participaçäo Política, Escola de Artes, Cièncias e Humanidades, Universidade de Säo Paulo Versäo corrigida

1. Museologia. 2. Museus - Aspectos sociais. I. Tomazzoni, Edegar Luis, orient. II. Título

CDD 22.ed. - 069 
Nome: RODRIGUES, Ana Paula Rosa

Título: As transformações do universo museal pelos paradigmas do conhecimento e o aprimoramento de sua função social a partir da Nova Museologia

Dissertação apresentada à Escola de Artes, Ciências e Humanidades da Universidade de São Paulo para a obtenção do Título de Mestre em Ciências pelo Programa de Pós-Graduação em Mudança Social e Participação Política.

Área de Concentração: Mudança Social e Participação Política

Aprovada em: 05 / 06 / 2019

\author{
Banca Examinadora \\ Prof. Dr. Edegar Luis Tomazzoni \\ Presidente \\ Universidade de São Paulo \\ Escola de Artes, Ciências e Humanidades \\ PROMUSPP
}
Profa. Dra. Sílvia Helena Zanirato Instituição Universidade de São Paulo
Escola de Artes, Ciências e Humanidades PROMUSPP

Prof. Dr. Glauber Eduardo de Oliveira Santos

Instituição

Universidade de São Paulo

Escola de Artes, Ciências e Humanidades PPGTUR

Profa. Dra. Valdirene Gomes dos Instituição Universidade Federal do Tocantins Santos de Jesus 
Dedico este trabalho à Mnemosyne.

Divindade que presenteou a humanidade com seu mais valioso atributo: a Memória 


\section{AGRADECIMENTOS}

De todos os sentimentos dos quais somos constituídos, a gratidão é o único essencialmente abnegado. A pureza de sentir e expressar algo que beneficie somente o outro, invariavelmente é substituída por sentimentos dos quais favorecemos somente a nós mesmos.

Por este motivo acredito que este item (equivocadamente) opcional (às vezes precisamos que nos obriguem a fazer o certo), mereça todo esforço ao qual também dediquei a minha pesquisa, pois ele concentra o exercício do reconhecimento e da valorização de quem contribuiu, viabilizou ou simplesmente incentivou a concretização dessa dissertação. Desta maneira, antecipadamente, agradeço e peço desculpas a todos cuja minha memória não permitiu o registro por escrito.

Meus mais sinceros agradecimentos a...

Minha família

- Meus avós maternos que o tempo e espaço de existência infelizmente não coincidiram com o meu, e meus avós paternos Maria e José exemplos de humildade e carinho.

-Minhas irmãs Thays Cristina Rodrigues, Érika Rosa Rodrigues e Camilla Cristina Rodrigues, companheiras de vida das quais me orgulho e me inspiro.

- Minha mãe Joaquina Rosa da Silva Rodrigues, uma flor que mesmo em tão pouco tempo semeou o amor, a bondade e a gratidão, seu legado me presenteou com o meu bem mais precioso, a vida.

- Meu Pai Paulo Sérgio Rodrigues, que mesmo o destino pregando-lhe uma terrível peça ao tirar sua companheira de vida, em nenhum momento renegou a nossa criação. Um raro exemplo de dedicação e amor paternal e maternal. Foram o seu apreço e esforço pela minha educação e de minhas irmãs que nos levaram (todas!) a ser a primeira geração de nossa família com um diploma de ensino superior.

Meus professores

- Infelizmente, não lembro o nome de cada um, por isso, de forma representativa agradeço a meiga Ruth, professora de educação infantil, que com um gesto de carinho ao revelar uma 
foto minha com uma linda dedicatória me fez sentir especial e capaz de enfrentar grandes desafios. Guardo esta foto até hoje.

- As professoras Sílvia Helena Zanirato e Madalena Aulicino, pelas valiosas contribuições feitas durante a banca de qualificação.

- A Professora Valdirene Gomes dos Santos de Jesus da Universidade Federal do Tocantins e gestora do Museu Histórico e Cultural de Arraias, por acreditar em meu trabalho e incentivar minhas ações.

A todas as Instituições de aprendizado formal, informal, e não formal que frequentei.

- As escolas: Escola Municipal Epitácio Pessoa, onde cursei a educação infantil; Escola Estadual Said Murad, onde cursei o ensino fundamental; Escola Estadual Professor Astrogildo Arruda, onde cursei o Ensino Médio e a ETEC Professor Aprígio Gonzaga, onde cursei o ensino técnico. Todas públicas situadas na Zona Leste de São Paulo.

- O Centro Cultural Alfredo Volpi e a Casa de Cultura de São Miguel, por preencher minha adolescência com experiências inesquecíveis.

- As universidades: Instituto Federal de São Paulo, na qual me graduei Tecnóloga em Turismo; Pontifícia Universidade Católica, onde graças a Política Pública Educacional PROUNI pude ter a possibilidade de mostrar a minha capacidade, enfrentando inúmeros desafios (sociais, econômicos e culturais) e me graduando como Bacharela em Administração de Empresas. Agradeço também a Universidade Federal do Tocantins - campus de Arraias, pela oportunidade de atuar como professora convidada no curso de Turismo Patrimonial e Socioambiental, proporcionando minha primeira experiência como docente.

Por fim, meu agradecimento especial...

- A todos os museus que tive o privilégio de conhecer. Em especial ao Museu Histórico e Cultural de Arraias (MHCA), pela oportunidade de compartilhar, dialogar, experimentar, aprender, acertar, errar, ousar e viver a Nova Museologia.

- A Universidade de São Paulo, principalmente ao Programa de Pós Graduação em Mudança Social e Participação Política, que de forma especial incentiva e acolhe pesquisas interdisciplinares como a minha. 
- Ao professor Edegar Luis Tomazzoni, meu orientador. Por aceitar iniciar esta empreitada comigo, por compreender a distância (São Paulo-Tocantins), pela correção minuciosa e atenciosa do meu texto, pelas palavras de reconhecimento e de incentivo, mas principalmente por fazer observações críticas de maneira sutil e construtiva, sem nunca, nunca mesmo faltar a educação.

Guardo então o meu último e mais afetuoso agradecimento ao meu ex-colega de faculdade, a pessoa que me incentivou a fazer este mestrado, que me acompanhou nas aulas, que deu ideias, elogiou, criticou, leu e releu este texto inúmeras vezes. Muito mais do que meu esposo, você é e sempre será o meu melhor amigo, companheiro de aventuras e desventuras nessa e nas próximas vidas...

Filipe Vieira de Oliveira, você é a minha inspiração. 
Eu vejo o futuro repetir o passado.

Eu vejo um museu de grandes novidades.

O tempo não para.

Não para não, não para...

Cazuza 


\section{RESUMO}

RODRIGUES, Ana Paula Rosa. As transformações do universo museal pelos paradigmas do conhecimento e o aprimoramento de sua função social a partir da Nova Museologia. 2019. 155 f. Dissertação (Mestrado em Ciências) - Escola de Artes, Ciências e Humanidades, Universidade de São Paulo, São Paulo, 2019. Versão Corrigida.

Ao longo da história, o Museu foi uma instituição de muitas características, finalidades e motivações, acompanhando as mudanças sociais de seu tempo. Ele possui hoje, um papel fundamental em diversos aspectos contemporâneos, compondo parte estruturante para o desenvolvimento da sociedade. Contudo, ele enfrenta grandes desafios para manter-se vivo e ativo em suas funções, o que nos leva a refletir se as instituições museais contemporâneas de fato cumprem a sua função social. Diante disso, o objetivo principal dessa dissertação foi analisar as transformações da instituição Museu, apresentando a sua trajetória a partir das mudanças dos paradigmas do conhecimento da sociedade. Como desdobramento desse objetivo e em virtude do movimento da Nova Museologia, a pesquisa teve como objetivo específico apresentar o Museu contemporâneo sob o prisma das novas formas de diálogo com a sociedade, trabalhando com a hipótese de que, essa mudança na postura museológica aproxima o museu da sociedade, contribuindo para o alcance e aprimoramento de sua função social. Buscando atingir tais objetivos, o método de pesquisa constituiu-se de uma abordagem qualitativa, exploratória e explicativa onde os procedimentos metodológicos foram aplicados as pesquisas bibliográfica e documental. Deste modo, a partir dos questionamentos: O que é conhecimento? O que é Museu? A que se destina? e A quem se destina? expostos em cada paradigma: Greco-Romano, Judaico-Cristão, Ciência Racional e o Paradigma Atual, elaboramos quadros com as respostas consolidadas para fundamentar reflexões acerca do passado, do presente e do futuro dos museus. Destacamos que em sua trajetória paradigmática de transformações e (re) transformações, o museu encontrou no movimento da Nova Museologia a busca pelo aprimoramento de sua função social. Nesse sentido, as análises feitas do passado, no Capítulo 2, e do presente, no Capítulo 3, nos permitiu que, no Capítulo 4 delineássemos a perspectiva de três novas formas de diálogos do museu com a sociedade: Diálogos por meio do Lazer Cultural, Diálogos por meio da Educação Não Formal e Diálogos por meio do Patrimônio Cultural, que a nosso ver, fazendo 
uso da criticidade e do desenvolvimento recíproco, favoreceriam o alcance das três finalidades prima do Museu (estudo, educação e lazer) e, consequentemente, o alcance e o aprimoramento de sua função social, razão de sua existência e objeto de estudo dessa pesquisa.

Palavras-chave: Museus. Paradigmas do conhecimento. Nova Museologia. Função social. 


\begin{abstract}
RODRIGUES, Ana Paula Rosa. The transformations of the museal universe by the paradigms of knowledge and the improvement of their social function from New Museology. 2019. 155 pages. Dissertation (Master of Science) - School of Arts, Sciences and Humanities, University of São Paulo, São Paulo, 2019. Corrected Version.
\end{abstract}

Throughout history, the Museum was an institution of many characteristics, purposes and motivations, accompanying the social changes of its time. Today, it has a fundamental role in several contemporary aspects, forming a structuring part for the development of society. However, it faces great challenges in order to remain alive and active in his functions, which leads us to reflect on whether contemporary museological institutions actually fulfill their social function. Therefore, the main objective of this dissertation was to analyze the transformations of the Museum institution, presenting its trajectory from the changes of the paradigms knowledge of the society. As a result of this objective and due to the New Museology movement, the research had as its specific objective to present the contemporary Museum under the prism of the new forms of dialogue with the society, considering the hypothesis that, this change in the museological methodology approaches the museum society, contributing to the achievement and improvement of its social function. In order to reach these objectives, the research method consisted of a qualitative, exploratory and explanatory approach where the methodological procedures were applied to bibliographical and documentary research. Thus, from the questions: What is knowledge? What is Museum? What is it for? and Who is it for? in each paradigm: Greco-Roman, Judeo-Christian, Rational Science and the Current Paradigm, we elaborate tables with the consolidated answers to support reflections about the past, the present and the future of the museums. We emphasize that in its paradigmatic trajectory of transformations and (re) transformations, the museum found in the movement of the New Museology the search for the improvement of its social function. In this sense, the analyzes of the past in Chapter 2 and in Chapter 3 have allowed us to delineate the perspective of three new forms of dialogues between the museum and society in Chapter 4: Dialogues through Cultural Leisure, Dialogues through Non-Formal Education and Dialogues through Cultural Heritage, which, in our view, making use of criticality and reciprocal development, would favor the achievement of the three primary purposes of the 
Museum (study, education and leisure) and, consequently, the scope and improvement of its social function, reason for its existence and the object of study of this research.

Keywords: Museums. Paradigms of knowledge. New Museology. Social role. 


\section{LISTA DE FIGURAS}

Figura 1: Processo Curatorial segundo Ulpiano Bezerra de Meneses....................................28

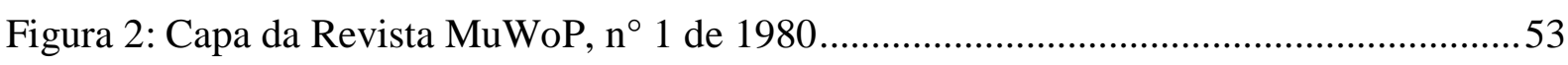

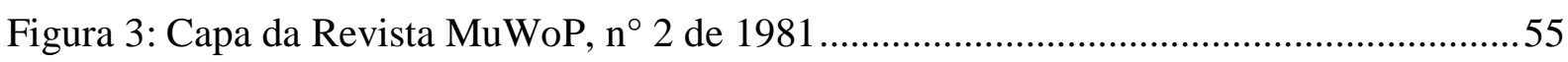

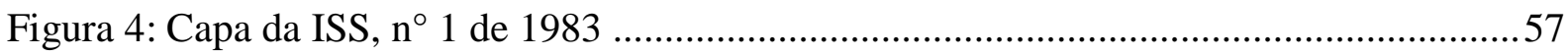

Figura 5: Capa da Série de Estudos do ICOFOM, n 46 de 2018 ..........................................63

Figura 6: Capa da Museum Internacional da UNESCO/ ICOM, vol. 70, nº 277-278 de 2018. . .65

Figura 7: novo lugar metodológico da museologia ......................................................... 70

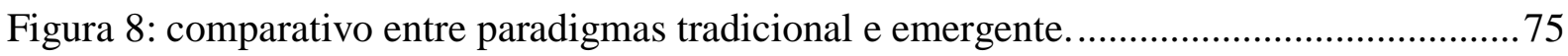

Figura 9: Comparativo entre museu tradicional, em transição e emergente. ...........................79

Figura 10: Exposição Castelo Ra-Tim-Bum no MIS em 2014 .............................................. 104

Figura 11: Slogan do Núcleo de Ação Educativa da Pinacoteca do Estado de São Paulo..... 115 


\section{LISTA DE QUADROS}

Quadro 1: Principais características $1^{\circ}$ Paradigma: Greco-Romano - Século IV a. C. - III d. C. 39

Quadro 2: Principais características $2^{\circ}$ Paradigma: Judaico-Cristão - Século IV- XIV ...........42

Quadro 3: Principais características $3^{\circ}$ Paradigma: Ciência Racional - Século XV- XIX.......46

Quadro 4: Principais características $4^{\circ}$ Paradigma: Atual - Século XX.................................78

Quadro 5: Relação entre as características do $4^{\circ}$ Paradigma e os elementos do Museu em

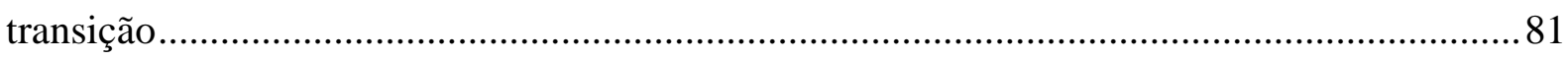

Quadro 6: Destaque referente a quem se destinava o Museu em cada paradigma do

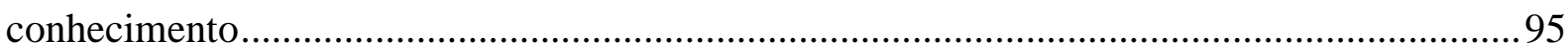

Quadro 7: Destaque referente ao que se destinava/ destina o Museu em cada paradigma do conhecimento

Quadro 8: Destaque referente ao o que é museu em cada Paradigma do Conhecimento 


\section{LISTA DE ABREVETURAS E SIGLAS}

$\begin{array}{ll}\text { EACH } & \text { Escola de Artes Ciências e Humanidades } \\ \text { IBRAM } & \text { Instituto Brasileiro de Museus } \\ \text { ICOFOM } & \text { Comitê Internacional para a Museologia } \\ \text { ICOFOM LAM } & \begin{array}{l}\text { Comitê Internacional para a Museologia para América Latina e Caribe } \\ \text { Conselho Internacional de Museus }\end{array} \\ \text { ICOM } & \text { Série de Estudos do ICOFOM } \\ \text { ISS } & \text { Movimento Internacional por uma Nova Museologia } \\ \text { MINON } & \text { Museu da Imagem e do Som } \\ \text { MIS } & \text { Museological Working Paper/ Documents de Travail sur La Muséologie } \\ \text { MuWoP/DoTraM } & \text { Núcleo de Ações educativas } \\ \text { NAE } & \text { Organização Internacional de Museus } \\ \text { OIM } & \text { Organização Internacional do Trabalho } \\ \text { OIT } & \text { Programas: Educativo para Públicos Especiais } \\ \text { PEPE } & \text { Programa de Inclusão Sociocultural } \\ \text { PISC } & \text { Programa de Pós-Graduação em Mundança Social e Participação Política } \\ \text { PROMUSPP } & \text { Serviço Social do Comércio } \\ \text { SESC } & \text { Universidade de Brasília } \\ \text { UNB } & \text { Organização da Nações Unidas para a Educação, a ciência e a Cultura } \\ \text { UNESCO } & \text { Universidadade de São Paulo }\end{array}$




\section{VOCABULÁRIO CONTROLADO SOBRE O UNIVERSO MUSEAL ${ }^{1}$}

Museal Relativo a museu.

Musealia $\quad$ Objeto de museus, Musealium.

Musealidade Relação específica do homem com a realidade; Também pode designar o caráter documental dos objetos.

Musealização Tornar-se museu.

Museografia Arte da exposição; conteúdo de um museu; figura prática ou aplicada da Museologia; conjunto de técnicas em relação com a Museologia.

Museologia Uma ciência em formação, dentro de suas áreas de estudo está a Musealidade.

\footnotetext{
${ }^{1}$ Para consulta aprofundada dos conceitos ver: http://www.icom.org.br/wpcontent/uploads/2014/03/PDF_Conceitos-Chave-de- Museologia
} 


\section{SUMÁRIO}

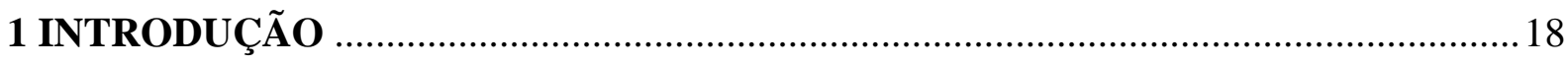

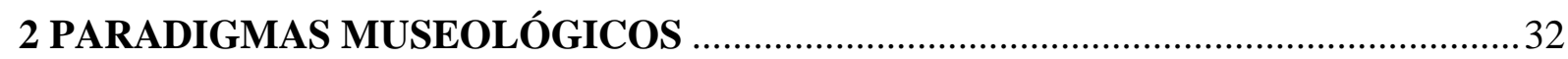

2.1. PARADIGMAS DO CONHECIMENTO E A TRAJETÓRIA DOS MUSEUS............33

2.1.1 $1^{\circ}$ Paradigma: Greco-Romano - Século IV a. C. - III d. C.................................. 36

2.1.2 2 ${ }^{\circ}$ Paradigma: Judaico-Cristão - Século IV - XIV ..........................................40

2.1.3 3 ${ }^{\circ}$ Paradigma: Ciência Racional - Século XV - XIX ........................................42

3 UM PARADIGMA EM CONSTRUÇÃO: UMA NOVA REALIDADE

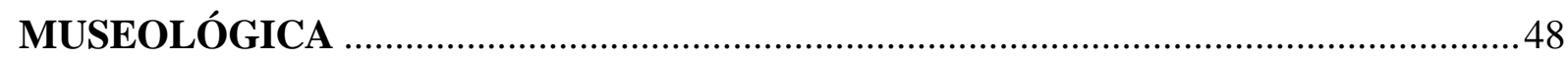

$3.14^{\circ}$ PARADIGMA ATUAL - SÉCULO XX.......................................................49

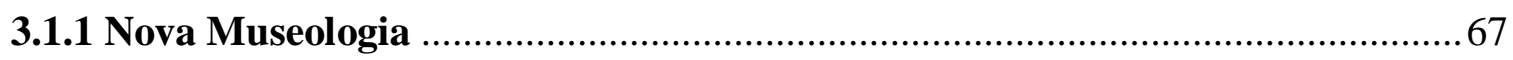

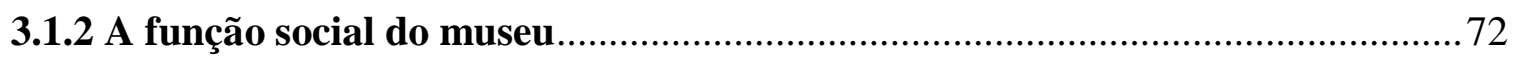

4 PARADIGMAS MUSEOLÓGICOS FUTUROS: MUSEUS INTERATIVOS,

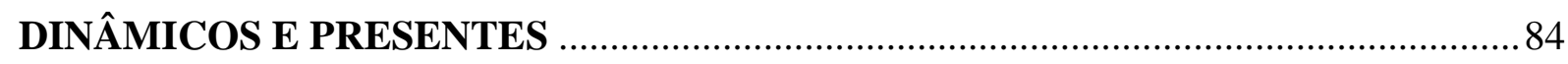

4.1 AS NOVAS FORMAS DE DIÁLOGO ENTRE O MUSEU E A SOCIEDADE ..........86

4.1.1 Diálogos por meio do Lazer Cultural ..................................................... 90

4.1.2 Diálogos por meio da Educação Não Formal ............................................ 108

4.1.3 Diálogos por meio do Patrimônio Cultural .................................................... 117

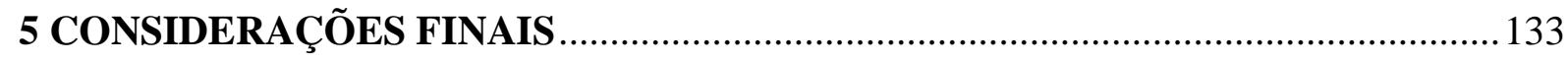

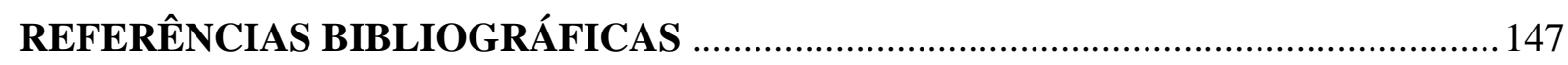




\section{INTRODUÇÃO}

Os museus vêm sendo cada vez mais procurados por um número crescente de visitantes, surgindo então uma relação cada vez mais promissora com os seus públicos. Ao longo do tempo, o Museu foi uma instituição de muitas características, finalidades e motivações, acompanhando as mudanças das sociedades em que estivessem inseridos, possuindo hoje, um papel fundamental em diversos aspectos, e expor estas relações nos traz, nesse sentido, a dimensão do que os museus com toda sua magnitude podem desenvolver.

Esta longa trajetória percorrida pelos museus não pode e nem deve ser tratada como singular, o seu tempo e espaço são plurais, dinâmicos, ativos e reativos. Pensar que podemos entendêla e interpretá-la pelo meio de acontecimentos lineares é reduzi-la apenas a fatos, retirando destes toda a riqueza das experiências dos sujeitos históricos nos ambientes onde eles se encontravam. Ao se desvencilhar do véu da cronologia, novos olhares destinados a esta relação ganham mais do que fatos históricos, são presenteados com a problemática histórica. Nesse cenário, onde as experiências humanas, o tempo e o espaço fazem parte de um mesmo contexto, instituições tais quais as museais em sua trajetória de transformações e (re) transformações figuram como um importante ator desta problemática, ainda que, as vezes como espectador mas muitas outras como protagonista.

Este conjunto de transformações proporcionou o perfil de museu da atualidade: mais participativo, dinâmico e ciente da sua responsabilidade social, resultado de anos de experiências instigadas por pessoas, momentos e movimentos de dentro e de fora do universo museal, em um processo contínuo e de permanente construção. A instituição Museu absorveu diversas funções, culminando hoje em uma complexa função social.

Assim, diante desse contexto, atualmente o Museu desempenha um papel estruturante no desenvolvimento da sociedade, contudo, enfrenta grandes desafios para manter-se vivo e ativo em suas funções. Assim sendo, evidenciamos a problemática desta pesquisa; tendo em vista sua trajetória paradigmática desde sua origem e, seu posicionamento e conduta a partir do movimento da Nova Museologia, as instituições museais contemporâneas cumprem a sua função social? 
Sob esta ótica e visando debater a problemática do contexto histórico em que os museus estão inseridos, o objetivo principal desta dissertação foi analisar as transformações da instituição Museu apresentando a sua trajetória a partir das mudanças dos paradigmas de conhecimento da sociedade. Como desdobramento deste objetivo e em virtude do movimento da Nova Museologia pertencente ao paradigma atual, a pesquisa teve como objetivo específico apresentar a Instituição Museu contemporânea sob o prisma das novas formas de diálogo com a sociedade, trabalhando com a hipótese de que, essa mudança na postura museológica aproxima o museu da sociedade, contribuindo para o alcance e aprimoramento de sua função social, objeto de estudo dessa pesquisa.

Para tanto, os conceitos que sustentaram a dissertação, estão fundamentados em autores que abordam a temática dos paradigmas do conhecimento - como um fenômeno científico, social e cultural, (KUHN, 2003; MORIN, 2000; SANTOS, 2006; SOUZA, 2017) e autores que apresentam a história do Museu - como uma instituição a serviço da sociedade (CASTRO, 2009; CHOAY, 2017; SUANO, 1986).

Visamos também analisar a função dos museus na sociedade contemporânea, assim fizemos uso de autores que abordam o movimento da Nova Museologia, bem como a problemática da função social dos museus (CERÁVOLO, 2004; BRUNO, 2006; CURY, 2008, 2009, 2014, 2014b; DUARTE, 2013; POULOT, 2013). Para então delinear um prisma das novas formas de diálogo do Museu com a sociedade, tarefa para a qual recorremos a autores que trabalham com as temáticas do Lazer (DUMAZEDIER, 1973, 2004; CAMARGO, 2001; MARCELLINO, 2000; GOMES, 2001; GOMES e MELO, 2003; BARRETO, 2007; TOMAZZONI, 2008; AULICINO, 2011;), da Educação, (FIGURELLI, 2011; FREIRE, 2011; SANTOS e GERMANO, 2015) e do Patrimônio Cultural, (ZANIRATO, 2009, 2018; SCHEINER, 2012; VARINE, 2013; CHOAY, 2017), entre outros.

O presente texto sob tais referenciais aborda alguns conceitos, bem como traça um histórico da relação entre os paradigmas do conhecimento e Museus com o intuito de fundamentar a discussão. Neste contexto, buscou-se analisar as transformações da instituição Museu apresentando a sua trajetória a partir das mudanças dos paradigmas do conhecimento da sociedade. Culminando com a abordagem das novas formas de diálogo do Museu, como possíveis meios de aproximação com os indivíduos e facilitadoras do cumprimento da função social inerente a essa instituição. 
Para alcançar os objetivos a partir desses referenciais, conforme aponta May (2004), os métodos de pesquisa constituem uma parte importante das ciências sociais e compõem um instrumento por meio do qual é promovido o seu desenvolvimento intelectual. Portanto, para atender aos objetivos principal e específico desta dissertação, o método de pesquisa seguirá os seguintes pontos:

- Do ponto de vista da abordagem do problema; a análise foi qualitativa com o intuito de compreender o fenômeno e seus significados.

A abordagem qualitativa não se preocupa com a representatividade numérica, mas sim com o aprofundamento da compreensão de um fator social. Para Severino (2013), ela possibilita a interpretação e a atribuição de significados aos fatos e elementos substanciais para a compreensão do fenômeno em pauta. Neste sentido, ao se tratar de um estudo que envolve as transformações, tanto da sociedade quanto do Museu, entendemos necessária, para fundamentar nossa análise, a compreensão de alguns fenômenos passados, presentes e futuros inerentes aos entrelaçamentos na trajetória de ambos: museu e sociedade. Diante disso acreditamos também que a instituição enfrenta grandes desafios para manter-se viva e ativa em suas funções. Tais desafios podem e devem ser encarados com o olhar qualitativo, para que a sua função social não seja comprometida.

A presente pesquisa concorda com May (2004) ao afirmar que o papel da ciência é entender e explicar os fenômenos sociais, focalizar a atenção em questões particulares e desafiar crenças convencionais sobre os mundos social e natural. Entretanto, devemos ter a clareza de que a pesquisa social difere das ciências naturais, pois os pesquisadores podem questionar aqueles a quem estudam, e este talvez seja o grande trunfo do pesquisador social muitas vezes relegado a segundo plano.

- Do ponto de vista dos objetivos da pesquisa; trata-se de uma pesquisa exploratória, que busca obter uma maior familiaridade da temática pesquisada para explicar alguns "porquês" encontrados na trajetória da dissertação.

Este tipo de pesquisa, além de proporcionar maior familiaridade com o tema, possibilita tornálo mais explícito e auxilia na construção de hipóteses. Neste sentido, ao se analisar de forma qualitativa os fatores que ocasionaram as transformações do Museu ao longo de sua trajetória, a pesquisa exploratória fornecerá elementos para compreender e aprimorar as formas de 
diálogo entre o Museu e a sociedade. Sendo assim, de forma complementar, mas ainda do ponto de vista do objetivo da pesquisa ela também será explicativa. Para Gil (2007) este tipo de pesquisa preocupa-se em identificar os fatores que determinam ou que contribuem para a ocorrência dos fenômenos, explicando o porquê das coisas por meio dos resultados oferecidos.

De acordo com Fonseca (2002) a pesquisa proporciona uma proximidade da realidade que se pretende investigar. Ela fornece elementos para a intervenção no real, ocorrendo através de sucessivas aproximações da realidade como em um processo em permanente construção, contudo, a pesquisa só existe com o apoio dos procedimentos metodológicos apropriados. Portanto, a partir do método de pesquisa anteriormente descrito, para viabilizar nossos objetivos, serão adotados os seguintes procedimentos metodológicos:

- Para a construção do conhecimento teórico conceitual; foi utilizada a pesquisa bibliográfica.

Constituída com base em material já elaborado, principalmente livros e artigos científicos, a principal vantagem da pesquisa bibliográfica, segundo Gil (2007), está no fato de permitir ao pesquisador a cobertura de um leque de fenômenos muito mais amplo do que aquela que poderia pesquisar de forma direta. Assim, além de possibilitar o levantamento das referências existentes e pertinentes à temática estudada, este tipo de pesquisa permitiu um maior aprofundamento teórico o que fundamentou este estudo, pois é a partir destes referenciais que apresentamos a análise das transformações do universo museal, mostrando a trajetória da instituição Museu por meio das mudanças dos paradigmas de conhecimento da sociedade.

Visando a alcançar o objetivo proposto por esta pesquisa e mantendo a coerência durante o texto, o fio condutor recorrente a todos os paradigmas do conhecimento são as respostas aos seguintes questionamentos:

\section{O que é conhecimento?}

\section{O que é museu?}

\section{A que se destina?}

\section{A quem se destina?}


As repostas obtidas por meio da pesquisa bibliográfica possibilitaram a construção de alguns cenários em diferentes contextos históricos, o que, mais do que fornecer verdades, provocam reflexões. Nesse sentido, a presente pesquisa concorda com Zanirato (2017) ao afirmar que “contar a história não se resume a contar a história, o que se entende por visão de mundo, o que e como se estrutura o conhecimento muda de acordo com o contexto histórico" (informação verbal) ${ }^{2}$.

A pesquisa bibliográfica foi o alicerce de toda a dissertação e de forma mais evidente nos Capítulos 2 e 3, onde utilizamos autores que fundamentam e apresentam reflexões sobre a trajetória tanto dos paradigmas do conhecimento, quanto da instituição Museu.

\section{- Para a abordagem das novas formas de diálogo do museu com a sociedade;} recorremos à pesquisa documental.

Além da utilização das fontes constituídas por material já elaborado, também utilizamos a pesquisa documental que possibilita recorrer a fontes mais diversificadas, contemporâneas e retrospectivas. Considerando os documentos cientificamente reconhecidos, a pesquisa valeuse de fontes de primeira mão que não receberam nenhum tratamento analítico, tais como: documentos oficiais acerca do universo museológico: estatutos (como os apresentados pelo Conselho Internacional de Museus - ICOM e pelo Comitê Internacional para a Museologia ICOFOM), Cartas e Declarações e Periódicos. Contamos também com figuras que contribuíram para demonstrar e principalmente para fundamentar análises de temáticas relativas a esta pesquisa. Nesta mesma linha usufruímos em alguns momentos de fontes secundárias que, de alguma forma, já tiveram suas informações analisadas, como relatórios e materiais produzidos por museus e disponibilizados abertamente.

Segundo May (2004, p. 205), a pesquisa documental "pode nos dizer muitas coisas sobre a maneira na qual os eventos são construídos, as justificativas empregadas, assim como fornecer materiais sobre as quais basear investigações mais aprofundadas". Nesse sentido, o levantamento das experiências museológicas nas redes sociais e sites oficiais de museus e do abrangente universo museal - hoje um importante canal de comunicação e de coleta de informações - também contribuíram para a concretização dos objetivos propostos.

\footnotetext{
${ }^{2}$ Informação oral obtida na arguição da professora Silvia Helena Zanirato durante banca de qualificação desta pesquisa em 07/06/2017.
} 
Portanto, em suma, para atender aos objetivos principal e específico deste estudo, o método de pesquisa consistiu em uma abordagem qualitativa no aspecto do fenômeno das transformações do Museu ao longo do tempo sob a ótica das mudanças de paradigmas do conhecimento, com objetivo exploratório e explicativo para entender os porquês destas transformações e levantar algumas hipóteses a respeito das novas formas de diálogo e a sua contribuição para o aperfeiçoamento da função social do museu, onde os procedimentos metodológicos seguidos balizaram-se na pesquisa bibliográfica e documental.

Durante muitos anos, o potencial de atração dos museus, ou seja, a capacidade de por si só atrair o visitante foi desencaminhado por vários estigmas, tais como: lugar de "velharia", espaço elitizado e templo da monotonia. Mas, com o passar do tempo, o Museu, assim como a sociedade, teve as suas mudanças, e os gestores passaram a enxergar a importância de se desenvolver diferentes formas de diálogo com a sociedade como uma maneira de aproximá-lo das pessoas, alavancando a sua visitação e ampliando a qualidade de sua prestação de serviços.

Cabe então para compreensão da temática proposta expor algumas vertentes de um questionamento central: afinal, o que é um museu?

Para iniciar uma reflexão que está em constante construção, exporemos três pontos de vista acerca da definição sobre o que é um museu: a de uma vertente mais administrativa proposta pelo Conselho Internacional de Museus (ICOM ${ }^{3}$ ), outra visão voltada ao âmbito do profissionalismo e a das proposições dentro da literatura museológica.

É interessante ressaltar que a trajetória da definição de museu, segundo os estatutos do ICOM, torna-se um tanto reveladora. Em julho de 1951, o estatuto afirmava que a palavra museu designa "qualquer estabelecimento permanente, administrado no interesse geral com o objetivo de conservar, estudar, valorizar por diversos meios" e, essencialmente, “expor para o prazer e a educação do público um conjunto de elementos de valor cultural: coleções de objetos artísticos, históricos, científicos e técnicos, jardins botânicos e zoológicos, aquários”.

\footnotetext{
${ }^{3}$ O Conselho Internacional de Museus (ICOM) é uma organização internacional de museus e de profissionais de museus, a quem está confiada a conservação, a preservação e a difusão do patrimônio mundial - cultural e natural, presente e futuro, material e imaterial - para a sociedade. Fundado em 1946 por Chauncey J. Hamlim, o ICOM objetiva a promoção e o desenvolvimento dos museus. É valorizado por se associar à UNESCO como organização não governamental.
} 
Adiante, em 1974, o ICOM apresentou uma definição que marcou uma reviravolta, ela afirmava que "o museu é uma instituição permanente, sem fins lucrativos, a serviço da sociedade e de seu desenvolvimento, aberta ao público, e que faz pesquisas relacionadas com os testemunhos materiais do ser humano e de seu ambiente, tendo em vista a aquisição, conservação, transmissão e, principalmente, exposição desse acervo com a finalidade de estudo, educação e deleite". Ano após ano acrescendo e aprimorando as suas diretrizes, em 2001 o ICOM apresenta a definição oficial de Museu, sendo adotada e mundialmente reconhecida nos dias atuais:

Museu é uma instituição permanente sem fins lucrativos, a serviço da sociedade e de seu desenvolvimento, aberta ao público, que adquire, conserva, pesquisa, comunica e expõe testemunhos materiais do homem e de seu meio, para fins de estudo, educação e lazer (Artigo 3 do Estatuto do ICOM, 2001).

Colaborando com a definição do ICOM, o Museu possui várias funções e valores perante a sociedade: preservar, investigar, educar, inovar, além de ser proativo e profissional. Quanto à finalidade, o Museu tem de atender a três características: estudo, educação e lazer. Para além de tais definições, as maneiras com as quais os museus apresentam-se e os significados que eles podem adquirir podem torná-los - dependendo de sua administração - instituições com longo alcance social, provedoras de experiências e investidos de um importante papel para o desenvolvimento e a valorização da cultura de uma sociedade.

Recentemente, em um documento intitulado Código de ética do ICOM para Museus de $2009^{4}$, o Conselho acresceu à definição de 2001 e ao conceito de testemunhos, a palavra imateriais, uma única palavra, mas que confere enorme amplitude ao objeto museológico. Destacando mais uma vez a necessidade de sempre acompanhar, absorver e debater novos pensamentos e caminhos da sociedade. Hoje em dia, as definições sobre o que é museu, obedecem com um grau maior ou menor de conformidade a essa proposta pelo ICOM de uma vertente mais administrativa, no entanto, faz-se necessário ampliar os horizontes deste conceito, agregando visões de diferentes atores que também compõem o universo museológico.

\footnotetext{
${ }^{4}$ Documento disponível em: icom.org.br
} 
Sobre uma definição inclinada ao âmbito profissional dos museus, Poulot (2013) nos diz que:

As diversas associações de conservadores no mundo inteiro chegaram, em geral, a definições semelhantes, mesmo que persistam desacordos evidentes no que diz respeito à natureza do museu e, sobretudo, à inclusão nessa categoria, ou não, de determinados estabelecimentos, tais como jardins zoológicos e botânicos, planetários, parques temáticos ou outros empreendimentos desse gênero. Os ministérios da Cultura ou as administrações culturais correspondentes empenharamse em definir as condições mínimas para ter direito ao título de museu e se beneficiar das subvenções públicas e apoios diversos, diferenciando-se da lei comum que rege as empresas de lazer e de diversão com fins lucrativos (POULOT, 2013, p.18).

O Museu, ou como o próprio Poulot (2013) trata, o "estabelecimento" museu precisa se enquadrar em certas condições legais ${ }^{5}$, tanto para estar apto a 'funcionamento' quanto para também receber alguns 'benefícios' próprios à instituição Museu, como por exemplo, a isenção de alguns impostos e taxas, e a participação em políticas públicas específicas. Não podemos esquecer que como estabelecimento o museu precisa se manter: pagar contas, salários, manutenção, efetivar compras etc. De fato, gerir um Museu é completamente diferente de administrar uma empresa de cunho exclusivamente comercial, todavia, apesar de por definição esta instituição não ter fins lucrativos ela precisa se manter em funcionamento e a razão de alguns museus terem fechado suas portas é justamente por terem falhado em sua gestão administrativa/financeira.

O profissionalismo ainda é uma ideia controversa dentro do universo museológico que durante anos se apegou a ideia de que as palavras "planejamento estratégico", "marketing", "administração financeira", manchariam a aura quase sacra a qual o Museu durante séculos esteve envolto. No entanto, apesar de o Museu ser uma instituição de ordem social como apresentado pelo ICOM, podemos dizer que ele também se assemelha a uma organização, no sentido de que, ele precisa combinar esforços individuais, de áreas e competências distintas

\footnotetext{
${ }^{5}$ De acordo com o Estatuto de Museus brasileiro, o Instituo Brasileiro de Museus (IBRAM) destaca as seguintes condições:1- Elaboração de um projeto para a criação do museu; 2- Estabelecimento da pessoa jurídica da instituição, regulamentada por diploma legal; 3- Contratação permanente de uma equipe interdisciplinar, composta, inclusive, de profissional museólogo para a realização dos procedimentos técnicos museológicos; 4Aprovações de um Regimento Interno - documento elaborado para estabelecer as normas de funcionamento do museu, desde a sua finalidade, propósitos, objetivos, política institucional, formas de manutenção, número de setores e/ou departamentos e seus respectivos funcionários, assim como a construção do seu organograma; 5Elaboração do Plano Museológico, conforme Artigo 46º da Lei 11.904, instrumento básico que definirá a missão, objetivos, públicos e programas.
} 
para alcançar o objetivo da instituição, ou seja, necessita, em seu dia a dia, de uma gestão eficiente, a fim de subsidiar o desempenho de sua função social, e essa é uma preocupação que deve ser assumida pelos cursos de Museologia. A esse respeito, Duarte (2012; 2014) preocupa-se e concorda com esse posicionamento, admitindo que a formação do museólogo deve também prepará-lo para atuar na gestão de museus.

Paralelamente as iniciativas administrativas e profissionais, a literatura museológica elaborou com regularidade suas próprias definições sobre o que é museu.

Os anos 1990 conheceram uma série de revisões que marcam a ausência de
identificação evidente de museu, assim como de museologia, contrariamente às
certezas da geração precedente. Em 1997, um dos museólogos europeus "clássicos",
Tomislav Sola, propõe a seguinte definição de museu: "Um museu é uma
organização sem fins lucrativos que coleciona, analisa, preserva e apresenta objetos
pertencentes ao patrimônio natural e cultural de maneira a aumentar a quantidade e a
qualidade dos conhecimentos. Um museu deve divertir seus visitantes e ajudá-los
a se distrair. Utilizando argumentos científicos e uma linguagem moderna, ele
deve ajudar os visitantes a compreender a experiência do passado. Em uma relação
mútua com seus usuários, ele deve encontrar nas experiências do passado a
sabedoria necessária para o presente e o futuro" (POULOT, 2013, p.2, grifo nosso).

Nesta visão mais acadêmica e também enriquecedora, podemos evidenciar que se trata de uma linguagem menos técnica, porém, mais abrangente, pautada nas relações em que o museu estabelece a preocupação com a qualidade dos conhecimentos, não deixando de associá-la à diversão do visitante, colocando de lado a ideia de que um museu preocupado com o lazer seria essencialmente alienante, ao contrário, nesta visão o lazer seria o canal para que com argumentos científicos e uma linguagem moderna em uma relação de via dupla (museuvisitante/visitante-museu) o conhecimento seja compartilhado.

Apresentado os pontos de vista administrativo, profissional e acadêmico das definições sobre o que é um museu, fica o seguinte questionamento:

Qual a importância de ter uma definição?

Há quem acredite que definir é restringir, mas a definição também pode ampliar horizontes até então desconsiderados pela falta de informação. Por exemplo, algumas instituições se apresentam sob a nomenclatura de museu, mas não atendem as funções e finalidades mínimas que um museu deve exercer. Assim como alguns estabelecimentos atendem a tais funções e 
finalidades, porém, não se apresentam como um museu, seja por não terem conhecimento, ou simplesmente por que não querem se apresentar como tal.

Neste caminho percorrido em busca de uma definição, houve grandes modificações do que é considerado um museu, como na citação de Poulot (2013, p. 3), onde é pontuado que há quem acredite que um zoológico é um museu, outros não. É nesta dinâmica que se apresenta o processo museal, sempre recebendo contribuições de diferentes visões, em constante construção. Apesar de não se tratar de objetos de estudo desta pesquisa, a título de reflexão acerca do que determina ou não a essência de um museu, questiona-se se modalidades como o Zoológico e o Jardim Botânico podem ser consideradas museus

\footnotetext{
A definição de um museu culmina, classicamente, na enumeração de suas funções. Um manifesto, publicado em abril de 1970, pelo futuro presidente da Associação Americana dos Museus, Joseph Veach Noble, identificava cinco funções: colecionar conservar, estudar, interpretar e expor. O museólogo holandês Peter Van Mensch prefere evocar somente três: preservar, educar e transmitir. (POULOT, 2013, p.22)
}

Com esta informação vamos aprimorar a nossa reflexão: o Zoológico e o Jardim Botânico desempenham as funções de um museu?

As três visões apresentadas: administrativa, profissional e acadêmica, apesar de algumas contribuições distintas possuem uma característica semelhante, todas se fundamentam nas funções que acreditam ser inerentes à existência do museu. Em conjunto podemos elencar algumas: preservar, investigar, pesquisar, educar, inovar, colecionar, coletar, conservar, estudar, interpretar, expor, transmitir, comunicar, dialogar. São funções que, para além de estarem presentes em definições, as pessoas esperam que o museu desempenhe, e a união destas e das inúmeras outras atribuídas a ele representam uma única grande função: a função social museológica.

Outro elemento para elucidar o questionamento anteriormente proposto, está na análise do processo curatorial, sendo a curadoria um conjunto de ações, o processo curatorial é fundamental para o cumprimento das funções de um museu. Para Cury (2009, p. 32), "curadoria ou processo curatorial é uma das formas de se entender o trabalho do museu, agora a partir da cadeia operatória em torno do objeto. A partir desta concepção, o papel do curador se amplia, ou seja, são curadores todos aqueles que participam do processo curatorial”. Dentre 
as diferentes concepções desse processo, destacamos a ideia de curadoria de Ulpiano Bezerra de Menezes, (Meneses apud Cury 2009), que nos permite, de forma contemporânea, entender como o processo curatorial organiza o cotidiano do museu e possibilita o alcance de suas funções.

Figura 1: Processo Curatorial segundo Ulpiano Bezerra de Meneses.

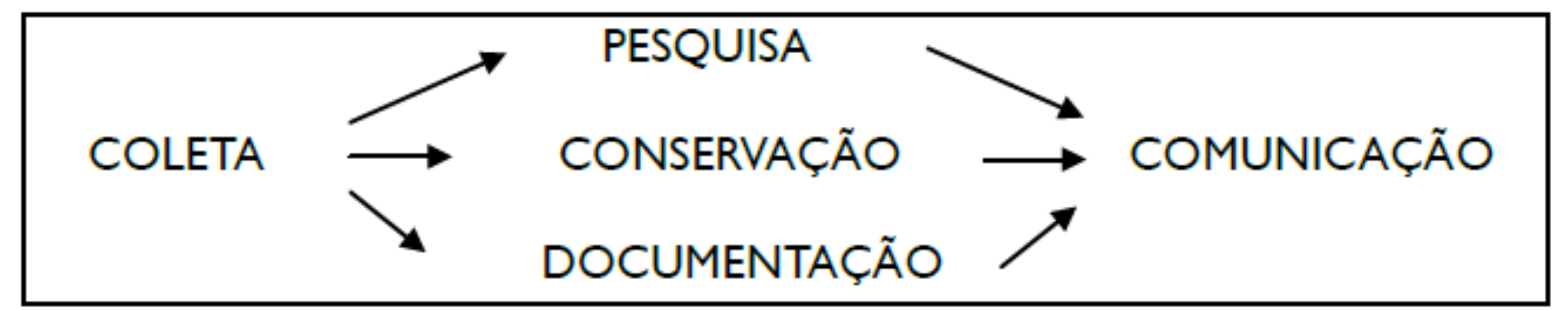

Fonte: Cury, 2014b.

Como podemos identificar na figura 1, trata-se de um processo formado por ações integradas: da coleta do objeto para a sua entrada no museu; da pesquisa do objeto tanto para a entrada quanto para a sua apresentação; da conservação do objeto para a manutenção e bom estado; da documentação para o seu controle e consulta (banco de dados); e da comunicação do objeto que pode ocorrer de inúmeras formas, sendo a mais conhecida a exposição. Essa estrutura, proposta por Meneses apud Cury (2009), explica artificialmente e didaticamente o processo, porém, no cotidiano não há certeza de que tudo aconteça sempre neste mesmo fluxo. $O$ processo curatorial pode se iniciar através da comunicação por exemplo. Apesar de áreas autônomas, a dinâmica do processo é de interação. Tudo acontece e interage, não há limites ou ordem, o que torna o processo ainda mais rico a cada acontecimento.

Retomando ao questionamento proposto anteriormente: Afinal, o Zoológico e o Jardim Botânico podem ser considerados museus?

Como dito anteriormente, ao invés de usar a definição para restringir a usaremos para ampliar horizontes. A resposta proposta por Meneses apud Cury (2009) é totalmente libertadora e reflexiva, ela nos permite usar o seu processo curatorial como instrumento de análise, ou seja, a partir dele podemos analisar: se um Zoológico coleta ao adquirir animais; ele os pesquisa, tanto para cuidados quanto para expor informações a seu respeito; ele os conserva por meio de cuidados diários com saúde, higiene, alimentação; ele documenta as informações dos animais 
para fins de controle e consulta; e por fim se ele os comunica ao expô-los ao público, - então, podemos concluir que sim, o Zoológico é um museu.

Ao usarmos esta mesma análise fundamentada nas ações do processo curatorial, concluiremos que o Jardim Botânico, na realidade, apesar de não se apresentar como tal, também é um museu. E o que pensar de um Cartório? A reflexão pode ir além e identificar também diversos casos em que uma determinada instituição tem a nomenclatura de museu, porém, não atende aos critérios propostos pelo processo curatorial. Como pudemos ver e exercitar, esta abordagem de Ulpiano Bezerra de Meneses para além de determinações, critérios e legislação, está fundamentada no que de fato a instituição pratica e não no que ela apenas diz fazer, nos transformando em uma espécie de "fiscais da prática museal".

Mesmo com base nas três visões: administrativa, profissional e acadêmica, e utilizando o processo curatorial apresentado por Meneses apud Cury (2009), podemos dizer que, definir o que é museu é uma tarefa quase tão difícil quanto definir a própria sociedade. São conceitos mutáveis pelo tempo histórico em que estão inseridos, visto que, as perspectivas acerca dos museus estão intrinsicamente relacionadas com as opiniões e ideologias de seu tempo e com a própria concepção que se tinha sobre o homem e a sociedade. Apesar de a definição proposta pelo ICOM ser amplamente aceita e utilizada nos dias atuais, ela também está sujeita a questionamentos e alterações, o que se torna relevante neste processo é que assim como a sociedade humana, a definição de Museu continuará se transformando, para que de fato corresponda com a realidade em que o museu se apresenta.

Para fins desta pesquisa e convenientemente para o alcance de nosso objetivo, adotaremos a definição mundialmente aceita; a apresentada pelo ICOM. Será por meio dela que delinearemos algumas análises a respeito das funções e finalidades museais. Todavia, encerramos este trecho de reflexões sobre a definição de Museu com as palavras de Scheiner (2012) que provoca ainda mais o sentido volátil e profundo do significado deste termo, indo além de uma definição, a autora aponta que: 
Museu é um fenômeno, identificável por meio de uma relação muito especial entre o humano, o espaço, o tempo e a memória, relação esta a que denominaremos 'musealidade'. A musealidade é um valor atribuído a certas 'dobras' do Real, a partir da percepção dos diferentes grupos humanos sobre a relação que estabelecem com o espaço, o tempo e a memória, em sintonia com os sistemas de pensamento e os valores de suas próprias culturas. E, portanto, a percepção (e o conceito) de musealidade poderá mudar, no tempo e no espaço, de acordo com os sistemas de pensamento das diferentes sociedades, em seu processo evolutivo. Assim, o que cada sociedade percebe e define como 'Museu' poderá também mudar, no tempo e no espaço (SCHEINER, p. 18, 2012).

Sob a inspiração desta relação muito especial apontada pela autora entre o humano, o espaço, o tempo e a memória, a qual ela denomina "musealidade", estruturamos esta pesquisa. A fim de analisar as transformações da instituição Museu apresentando a sua trajetória a partir das mudanças dos paradigmas de conhecimento da sociedade, mergulharemos nas 'dobras' do Real de Scheiner. Assim, estruturamos a pesquisa em cinco capítulos, sendo três deles representativos: o Capítulo 2 apresenta as dobras do passado, o Capítulo 3 as dobras do presente e o Capítulo 4 as dobras do futuro, tentando respeitar em cada um, a percepção dos diferentes grupos humanos sobre a relação que estabelecem com o espaço, o tempo e a memória, em sintonia com os sistemas de pensamento e os valores de suas próprias culturas.

Tendo em vista os conceitos e as reflexões propostas até o momento, o texto segue pelo Capítulo 2 Paradigmas Museológicos, em que será exposta uma análise das transformações da instituição Museu apresentando a trajetória da instituição a partir das mudanças dos paradigmas de conhecimento da sociedade, usando as respostas aos questionamentos sobre: $\mathrm{O}$ que é conhecimento? O que é Museu? A que se destina? e A quem se destina? Como elementos construtores de um cenário que possibilite fundamentar reflexões, entendendo que a trajetória dos museus está repleta de diferentes contextos históricos, cujas subsequentes influências ocasionaram mudanças que não ocorreram de forma tranquila ou uniforme, isto é, desde o surgimento do Mouseion na Grécia antiga até a concepção do museu contemporâneo, os caminhos que esta instituição percorreu, percorre e percorrerá foi e será fruto de muitos aprendizados, avanços, retrocessos, aprendizados, avanços, retrocessos...

E é em decorrência das reflexões históricas propostas no segundo capítulo, que em seguida no Capítulo 3 Um paradigma em construção, uma nova realidade museológica, a pesquisa ingressa no aspecto das problemáticas mais contemporâneas, iniciando pela concepção proposta 
pela Nova Museologia a respeito da função social dos museus, para então a partir da crescente necessidade de comunicação que visa ao aprimoramento desta função, compreender as diferentes formas de diálogo entre o museu e a sociedade.

Assim, as análises feitas do passado no Capítulo 2 e do presente no Capítulo 3, nos permitiu que no quarto e último Capítulo, Paradigmas Museológicos Futuros: museus interativos, dinâmicos e presentes delineássemos a perspectiva de três novas formas de diálogos do museu com a sociedade, diálogos estes, que a nosso ver, fazendo uso da criticidade e do desenvolvimento recíproco, favoreceriam no alcance das três finalidades prima do museu (estudo, educação e lazer) e consequentemente por meio do aprimoramento de sua função social, culminariam na contribuição para o desenvolvimento da sociedade. 


\section{PARADIGMAS MUSEOLÓGICOS}

Nasce o Mouseion na Grécia. Aparece no Egito dos Ptolomeus.

Reduz sua pretensão enciclopédica. Livra-se da antiga estrutura, torna-se compêndio sobre metais, lista de especiarias, livro de canções e poemas.

Em meio à violência dos saques, os troféus desfilam as glórias e o prestigio das vitórias. Coleções, frutos da pilhagem, espalham-se pelas ruas e pelas praças.

O colecionador confina os objetos em gabinetes, galerias de aparato, pinacotecas. Raridades, símbolos místicos, curiosidades, cabeças coroadas sucedem-se, escondidas, em salas reservadas de palácios.

Abrem-se os portões. Não mais o privilégio de alguns, mas patrimônio coletivo dos povos. O museu retém o tempo. As musas donas da memória, continuam estrelas-guias de um passeio sideral. Nostalgias cósmicas do que foi.

O mundo se redescobre a cada dia. Novas perspectivas inauguram caminhos. $O$ museu redimensiona-se. Antes passivo, ordena-se ativo. Não mais o objeto em si mas o resumo histórico. A interdependência cultural, a rede trançada nos fios que se entrecruzam por entre passado, presente e futuro. $\underline{O}$ museu reajusta a sua função didática. Faz coincidir o estético e o pedagógico. Conceitua-se no contexto histórico e por área geográfica. Cada museu responde a algum aspecto do saber

humano. Concentra-se, especializa-se e torna-se, antagonicamente, mais amplo. O método visual é a sua linguagem.

Uma nova situação o aguarda: o existir tradicional e a forma viva, combinados com o avanço que o progresso humano coloca à sua disposição.

Autora: Priscila Freire. Apresentação do livro O Museu e a vida ${ }^{6}$, de GIRALDY, Danièle; BOUILHET, Henri, 1990.

\footnotetext{
${ }^{6}$ Grifo nosso: partes destacadas deste texto/poema serão inseridas, contextualizadas e explicadas no decorrer desta pesquisa.
} 


\subsection{PARADIGMAS DO CONHECIMENTO E A TRAJETÓRIA DOS MUSEUS}

Ao longo da história das civilizações podemos perceber que o conhecimento científico foi utilizado pelo ser humano para organizar-se em sociedade. Compreender estes diferentes momentos do uso da ciência é importante para constatarmos a influência da cultura na construção e reconstrução de nossos paradigmas.

Em busca de tal compreensão, realizou-se uma pesquisa bibliográfica onde, entre outros, foram abordados autores da filosofia da ciência, dentre estes, Thomas Kuhn (1970) (2003), Edgar Morin (2000), Boaventura de Sousa Santos (2006) e Rubem Alves (1981). Autores estes trabalhados na disciplina obrigatória do programa de Pós-Graduação em Mudança Social e Participação Política da Universidade de São Paulo, ministrada pelos professores Silvia Helena Zanirato e Marcos Bernardino de Carvalho.

No sentido etimológico, o termo paradigma vem do grego parádeigma, e no latim paradigma, ambos com o mesmo significado: padrão, modelo. No universo científico a aplicação do termo paradigma é feito pela primeira vez por Thomas Kuhn (1970) para apontar

[...] mudanças radicais, por ele observadas na ciência normal. Todavia, seu uso mais recente, em especial, ocorre na área da pesquisa qualitativa, em que é dado como sinônimo de teoria, com as expressões: "orientação teórica" ou "perspectiva teórica", significando o entendimento do mundo, das asserções que as pessoas têm sobre o que é importante para o mundo funcionar (KUHN, 1970, p.218).

O conceito de Kuhn (1970) designa paradigmas como mudanças radicais, adiante especificado como "toda uma constelação de crenças, valores, técnicas, etc., partilhadas pelos membros de uma comunidade determinada" (1970, p. 218), posteriormente, esta definição do paradigma científico é abarcada por Capra (1996, p. 24), todavia, em um âmbito social como: “ uma constelação de concepções, valores, percepções e práticas compartilhadas por uma comunidade e que dá forma a uma visão particular de realidade, a qual constitui a maneira pela qual a comunidade se organiza”. Contudo, este pensamento não é de forma alguma isolado, Santos (2006) em sua obra Um discurso sobre as ciências enfatiza o laço estreito entre Sociedade, Cultura e Tecnologia, onde o conhecimento é duplamente contextualizado pela comunidade científica e pela sociedade. 
Recorremos novamente a Kuhn (2003, p.260), para apontar que "o conhecimento científico, como a linguagem, é intrinsecamente a propriedade comum de um grupo ou então não é nada". O autor ainda articula que para entendê-lo, "precisaríamos conhecer as características essenciais dos grupos que o criam e o utilizam”. Assim Kuhn nos dá a dimensão de quão estreito é este laço entre o conhecimento e a sociedade como um todo, e não apenas a sociedade científica.

A ideia de Paradigma, em seu princípio amplamente associada ao universo científico (essencialmente da física quântica), ganha então novas faces e é expandido. A compreensão dos Paradigmas em seu aspecto social passa a compor o que hoje abordamos como Paradigmas do Conhecimento, onde o universo científico não é isolado, ele compõe, influencia e é influenciado pelo universo social. Neste sentido, Souza (2017) considera que:

Um "Paradigma" é o horizonte histórico que define os pressupostos para qualquer tipo de conhecimento. Normalmente, todas as pessoas são influenciadas pelo paradigma na qual são criadas e ninguém, em condições normais, pensa além de seu tempo. Isso acontece tanto nas ciências exatas quanto nas ciências humanas e sociais. (SOUZA, 2017, p.14)

Portanto, podemos apontar que a compreensão de realidade e da percepção de mundo de uma determinada época orientam e esclarecem ao pesquisador atual como era concebida a visão de conhecimento, que norteia e dá sentido a qualquer sociedade. Considerar os aspectos históricos e culturais é de suma importância para compreendermos os referenciais que deram sustentação a cada paradigma. Tanto que para Kuhn (2003, p.150) “o que um homem vê depende tanto daquilo que ele olha como daquilo que sua experiência visual-conceitual prévia o ensinou a ver”. Neste momento, é necessário destacar, porém, que o surgimento de um novo paradigma não está relacionado a uma concepção cronológica de espaço e tempo e sim por uma série de acontecimentos que envolvem traços culturais de sua época.

Então, como determinar quando estamos vivendo em um novo paradigma?

As mudanças sociais culminam inevitavelmente em uma crise do paradigma vigente, Kuhn (2003) lembra que novas descobertas proporcionam mudanças de paradigmas ou contribuem para tanto. Além disso, as mudanças nas quais essas descobertas estiveram implicadas foram, todas elas, tanto construtivas como destrutivas. Ele também coloca que as crises são uma pré- 
condição necessária para a emergência de novas teorias. Perguntemos então: como os cientistas respondem à sua existência? $\mathrm{O}$ autor argumenta que "o significado das crises consiste exatamente no fato de que indicam que é chegada a ocasião para renovar os instrumentos" (KUHN, 2003, p.105-107).

Deste modo, os paradigmas como parte constitutiva da ciência, e a ciência como parte constitutiva do homem (consequentemente da sociedade), estão, logo, ambos em constante aprendizado. O avanço efetivo do conhecimento de acordo com Souza (2017) se dá com a superação de paradigmas envelhecidos, mais do que pela mera adição de conhecimentos dentro do contexto de paradigmas superados.

A noção de paradigma apresenta inúmeros apontamentos, observamos em síntese a complexa simplicidade de Santos (2006) ao afirmar que, "um paradigma é um modelo explicativo do conhecimento". Daí surge a questão central, e quem sabe ainda mais profunda: O que é conhecimento?

Talvez para respondermos a este questionamento, seja preciso reformular a pergunta para: $\mathrm{O}$ que dizem ser conhecimento?

A fim de introduzir algumas reflexões acerca deste questionamento usaremos como base a Filosofia da Ciência, que através da história da filosofia e da teoria do conhecimento nos fornece informações relevantes a essa indagação, como por exemplo, no que diz respeito as mudanças no entendimento de Ciência, visto que, o que estudamos hoje seria visto completamente diferente há cem anos. Neste aspecto, recorremos novamente a Kuhn (2003), para ele "o historiador da ciência que examinar as pesquisas do passado a partir da perspectiva de historiografia contemporânea pode sentir-se tentado a proclamar que, quando mudam os paradigmas, muda com eles o próprio mundo" (KUHN, 2003, p.147).

E aí encontra-se uma grande armadilha, um paradigma do conhecimento mesmo que envolto na mais exata das ciências encontrará sua fundamentação no contexto cultural de seu surgimento, por isso, ao falarmos de tal assunto precisamos nos despir ao máximo possível de nossos preceitos contemporâneos e orientar nosso olhar para cada época da maneira mais isenta que nos é permitido, visto que, em épocas diferentes, diversas escolas fizeram contribuições significativas ao corpo de conceitos, aos quais só podemos enxergar se nos desvencilharmos de alguns conhecimentos atuais. 
Munidos agora de algumas inquietações, retornaremos neste momento ao universo museal. Ao afirmamos na introdução desta dissertação que os museus ao longo do tempo foram instituições com muitas características, finalidades e motivações, acompanhando as mudanças da sociedade em que estivessem inseridos, estamos dizendo, portanto, que a cada mudança de paradigma da sociedade, o Museu também sofreu uma mudança paradigmática, ou, utilizando a ideia de complexidade ${ }^{7}$ de Edgar Morin, por que não dizer que, sendo o Museu um expoente cultural de uma determinada sociedade, ele outrora fora o agente central responsável pela quebra de um paradigma. Desvendar estas relações passadas nos traz a amplitude do que os museus contemporâneos podem desempenhar.

O que se segue agora é uma análise paralela, mas, ao mesmo tempo, complementar da trajetória da instituição Museu e das mudanças de paradigma do conhecimento, em busca das contribuições de todos os paradigmas para a construção dessa instituição como a conhecemos hoje. Para tanto, reforçamos que o fio condutor recorrente a apresentação e análise de todos os paradigmas do conhecimento são as respostas aos seguintes questionamentos: O que é conhecimento? O que é museu? A que se destina? A quem se destina?

Entendendo os paradigmas como modelos de produção do conhecimento durante um determinado período, o mundo ocidental conheceu ao menos quatro paradigmas ao longo da história, ou seja, passou por quatro formas diferentes de compreensão do mundo, vejamos agora como a história do museu se encaixa em cada um destes paradigmas:

\subsection{1 $1^{\circ}$ Paradigma: Greco-Romano - Século IV a. C. - III d. C.}

O primeiro Paradigma, também conhecido como Paradigma Indiciário, por fundamentar a verdade em indícios, possuía como principal característica a capacidade discursiva, visto que a oratória era responsável por levar a história adiante. Daí surge outra característica essencial para este período: a retórica, já que se tratava de também convencer o ouvinte.

As respostas para as perguntas essenciais da realidade em que se vive, tais como, as origens e valores de um povo tinham como base o mundo mítico. De maneira fantasiosa, o mito utilizava-se do mistério e até do sobrenatural para regrar e fundamentar uma visão de mundo,

\footnotetext{
${ }^{7}$ Sobre complexidade, ver MORIN, Edgar. Introdução ao pensamento complexo, 2011.
} 
seja na Grécia antiga ou em algumas tribos em que o trovão era tido como prova da fúria de uma das muitas divindades existentes.

Envolto nessas características do Paradigma Greco-Romano, o sentido mais próximo do conceito moderno de museu é encontrado na Grécia antiga - o surgimento dos museus como locais de preservação de objetos com finalidade cultural, por diferentes motivações, é muito mais antigo, desde tempos longínquos o homem se dedica a atividade de colecionar objetos. No entanto, a origem etimológica clássica da palavra museu é grega - mouseion ou casa das Musas, locais que situavam-se nos santuários dos templos dedicados as Musas sendo uma mistura de templo e de instituição de pesquisa, voltado, sobretudo, ao saber filosófico. Podemos então dizer, que durante este Paradigma em que nasce o Mouseion na Grécia, nasce também o conceito de instituição museal.

Filhas de Zeus com Mnemosyne, a divindade da memória, as Musas eram também divindades, cada qual com uma atribuição. Hesíodo em seu livro Teogonia apresenta as Musas da seguinte forma: Calíope a primeira das irmãs, musa da eloquência, Clío musa da história, Euterpe musa da poesia lírica, Tália musa da comédia, Melpômene musa da tragédia, Terpsícore musa da dança, Érato musa dos versos eróticos, Polímnia musa dos hinos e a narradora de histórias e Urânia musa da astronomia (CASTRO, 2009).

Utilizando-se da fantasia característica deste período, essas divindades ajudavam os homens a esquecer a ansiedade e a tristeza por meio de suas danças, músicas e principalmente de sua narrativa pautada na absoluta memória herdada de sua mãe, Mnemosyne (CASTRO, 2009).

Sob tal inspiração, Castro (2009, p. 37) aponta que, “o Mouseion grego era uma construção localizada em Atenas, destinado aos eruditos que cultivavam a poesia, música, estudos filosóficos e apreciavam exposições de artes, constituindo-se em uma irmandade religiosa dedicada a meditações sob a inspiração das Musas", expondo assim qual era o ideal de conhecimento a ser atingido na época. O Mouseion configura-se então como um local primoroso, que de acordo com Suano (1986) apresenta-se como um lugar onde se repousava a mente e onde o pensamento era profundo e criativo, liberto dos problemas e aflições cotidianos, onde o visitante poderia se dedicar às artes e às ciências.

Assim sendo, por reunir eruditos dedicados à estudos e meditações, podemos dizer que de certa forma a educação (ainda que destinada à poucos) começa a ser associada ao conceito de 
Museu. Esses templos também recebiam oferendas (objetos de grande valor ou estima e até mesmo exóticos) que podiam ser exibidos ao público, mas as obras de arte expostas no Mouseion existiam mais em função de agradar ao mito das divindades do que para serem contempladas pelo homem, descartando, por enquanto, a ideia contemporânea de 'exposição' (CASTRO, 2009).

Dos museus da antiguidade, talvez o mais conhecido seja o de Alexandria. Criado a partir da dinastia dos Ptolomeus no Egito do século II a.C. com o objetivo de dar proteção e perenidade a história, ciências e artes das dinastias. Ele continha estátuas de filósofos, objetos astronômicos e cirúrgicos, exemplares exóticos, tais como, peles de animais raros, presas de elefantes, pedras e minérios trazidos de lugares distantes, além de um parque zoobotânico e da sua ainda mais famosa biblioteca. Bosi (1987, p. 48) aponta que este verdadeiro complexo cultural era "frequentado pelos mais destacados sábios e poetas do mundo grego e egípcio. Instituições que se impulsionavam como protetoras da memória, da reminiscência, cujas evocações às Musas propiciavam dar voz a seus interpretes, os artistas”.

Entre salas de trabalho, refeitório, anfiteatro, observatório, e é claro, um santuário às Musas, o Museu de Alexandria configurava-se em um "ativo centro de pesquisa e informação cultural", (CASTRO, 2009, p. 37) e primava pela plena integração dos povos em torno do saber, pois: diversos matemáticos, médicos, historiadores, poetas, geólogos, astrônomos e filósofos vindos de diferentes partes do mundo contribuíram na composição do museu e de sua biblioteca seguindo os anseios do seu paradigma do conhecimento, Suano (1986) cita que, dentre os grandes trabalhos dispostos no museu de Alexandria figuravam um sumário do pensamento filosófico e um detalhado dicionário de mitos, mostrando assim que os Romanos valorizaram e recriaram muitas das criações artísticas da cultura grega, divulgando-a ao mundo ocidental.

Audaciosamente pluridisciplinar, o grandioso Mouseion de Alexandria era também conhecido pela sua preocupação com o saber enciclopédico, Suano (1986) identifica que, de posse deste rico material (em sua imensa maioria coleções, frutos da pilhagem das legiões), buscava-se discutir e ensinar de maneira discursiva todo o saber existente nos campos da religião, mitologia, astronomia, filosofia, medicina, zoologia, geografia, etc, em uma compilação exaustiva, quase completa, sobre um determinado tema. O Museu então mostra a sua pretensão enciclopédica, que perduraria por muitos anos. 
Os significados que o Museu possui neste primeiro Paradigma podem ser encontrados ainda hoje, remodelados e aperfeiçoados, mas em sua natureza e essência com algumas similaridades aos deste paradigma inicial. É importante, aqui, pontuar que, quando tratamos do museu enquanto templo das Musas na antiga Grécia ou do grande museu de Alexandria, não estamos afirmando que eles foram modelos de museu como o conhecemos hoje, trata-se de conceitos diferentes, mas que compartilham um certo imaginário museal. É fato que os museus modernos não possuem a função de um templo, mas podemos dizer que além de todas as funções que o museu da atualidade adquiriu ao longo do tempo, ele ainda é também um local dedicado à adoração, contemplação e a busca por inspiração, só que não mais das divindades mitológicas da antiguidade.

No Quadro 1, para melhor reflexão, sintetizamos as respostas referentes aos questionamentos condutores da análise associativa entre os paradigmas do conhecimento e a trajetória museal, encontradas durante a apresentação do $1^{\circ}$ Paradigma.

Quadro 1: Principais características $1^{\circ}$ Paradigma: Greco-Romano - Século IV a. C. - III d. C.

Greco Romano

O que é conhecimento? Saber Filosófico

Uma mistura de Templo e Instituição de Um conjunto grandioso de instalações Pesquisa com diversas finalidades

A que se destina? Ao estudo das Artes e Ciências

A quem se destina? Quem o frequenta?

Eruditos Gregos
Saber Enciclopédico

A Perpetuidade e Proteção da história, ciências e artes de uma Dinastia

Estudiosos de diversas áreas do saber e diferentes nacionalidades

Fonte: Elaboração própria, 2018.

O inspirador conhecimento Greco-Romano e a sua rica mitologia, além de pioneiros em vários aspectos da filosofia, democracia, arquitetura, matemática, artes entre outros, apresentam-se como temas recorrentes em diversas obras de arte espalhadas em museus ao redor do mundo contemporâneo. Deste modo, o legado deste período tornou-se um dos pilares da sociedade ocidental, tanto por seu modo de vida quanto pelos conhecimentos que 
regeram e que ainda regem as ciências contemporâneas, uma herança tanto para o universo museológico quanto para a ciência.

\subsection{2 $2^{\circ}$ Paradigma: Judaico-Cristão - Século IV- XIV}

Neste segundo Paradigma compreendido quase em sua totalidade pelo período conhecido como Idade Média, a religião veio substituir o mítico, somado a oratória aprimorou-se a escrita, o que ajudou a difundir a religião de um só Deus. Além da substituição de um conjunto de deuses por um único Deus 'onipotente' e 'onipresente', a partir das contribuições de São Tomás de Aquino, podemos afirmar que no que diz respeito à noção de conhecimento, a igreja é consolidada como detentora do saber e as respostas passaram a ser baseadas na "vontade de Deus".

Indo mais além podemos salientar que todo conhecimento que fosse divergente deste observado no parágrafo anterior, era tido como perigoso e, portanto, imediatamente tolhido, o que a título de ilustração foi representado na cena do filme $O$ nome da Rosa, do diretor JeanJacques Annaud de 1986, onde as páginas do livro $2^{\circ}$ livro da Poética de Aristóteles que versava sobre a comédia estavam cheias de veneno, punindo assim com a morte imediata, aos que ousavam folhear suas páginas em busca daquele tipo de conhecimento.

Em meio a este novo entendimento de mundo, a noção de Museu quase se perdeu, mas o colecionismo $^{8}$ ganhou notabilidade e sustentou a instituição, chegando a séculos mais tarde ser a fonte para acervos de inúmeros museus pelo mundo. Figuras religiosas, comandantes de exércitos, nobreza... o colecionador confina os objetos em gabinetes. A coleção tem o poder de 'espelhar grandeza', de 'afirmação social' ou de 'sobrevivência', visto que, estas coleções de preciosidades eram consideradas também uma reserva a ser convertida em divisas em caso de necessidade. Demonstração de riqueza e de "bom gosto", as coleções frutos de espólios de guerra também ilustravam o poder e a grandeza do inimigo sobrepujado pelo colecionador.

\footnotetext{
${ }^{8}$ Sobre Colecionismo ver, SUANO, Marlene. O que é museu, 1986; GIRALDY, Danièle; BOUILHET, Henri. O museu e a vida, 1990.
} 
A igreja deste período, além de autoproclamada detentora do saber, também era tida como guardiã das artes, visto que, ao pregar o "despojamento pessoal de riquezas e bens supérfluos, ela passa a ser a principal receptora de doações” (SUANO, 1986, p. 14).

A igreja, possuidora de extensos tesouros, passa a formalizar pactos políticos e alianças econômicas importantes para a manutenção do poderio papal. Em nome da campanha de despojamento pessoal, na prerrogativa de principal receptora das doações dos fiéis, obtém reforço significativo em seu já respeitável acervo. (CASTRO, 2009, p. 46)

De posse deste respeitável e grandioso acervo inicialmente destinado apenas ao alto clero, a igreja percebe o potencial de comunicação da arte e investe então na arte enquanto "meio de instrução religiosa e utiliza a ilustração visual por meio de pinturas, esculturas, murais, mosaicos, vitrais, tapeçarias" fator que, mesmo sem ser esta a intenção impulsiona "maior contato com as obras artísticas pela população”, ocasionando assim os primeiros passos em direção a abertura das coleções à visitação pública (CASTRO, 2009, p. 46).

Muito além da religião a Igreja deste paradigma representa uma grande força política que utilizava os seus tesouros para "lastrear alianças, formalizar pactos políticos e financiar guerras contra os inimigos do Estado Papal” (SUANO, 1986, p. 14).

Já no fim deste paradigma, surge outro componente deste cenário da história museal, os príncipes, com os seus grandiosos tesouros privados, cujas coleções serão fortalecidas em meio ao próximo paradigma.

Rei após Rei, Papa após Papa, muitos dos objetos que hoje temos disponíveis e expostos em vitrines de museus provem de salas reservadas de palácios, catedrais e mosteiros. Valiosas coleções se formaram com objetos ligados à religião: relíquias de santos, manuscritos, aparatos litúrgicos, obras de arte que exaltam as criações divinas (como a natureza), e também inúmeras peças 'pagãs', muitas vezes, confiscadas pela igreja e que hoje compõem os riquíssimos acervos, principalmente, dos museus europeus.

Diante do exposto, exibimos no Quadro 2 as respostas aos questionamentos condutores da análise associativa entre os paradigmas do conhecimento e a trajetória museal, consolidadas neste $2^{\circ}$ Paradigma. 
Quadro 2: Principais características $2^{\circ}$ Paradigma: Judaico-Cristão - Século IV- XIV

Nobreza Clero

O que é conhecimento? Saber religioso "vontade de Deus"

Coleções particulares da Nobreza

O que é museu?

A que se destina? Demonstração de grandeza

A quem se destina?

Quem o frequenta?

Ao círculo social da nobreza

Saber religioso "vontade de Deus"

Coleções particulares da Igreja

Demonstração de grandeza e instrução religiosa

Inicialmente, exclusivamente ao clero e posteriormente também aos fiéis

Fonte: Elaboração própria, 2018.

É neste paradigma que vislumbramos em toda a sua plenitude o poder que as instituições museológicas possuem, e principalmente o poder que elas podem atribuir a quem as manipula. Diante de um período de guerras e disputas pelo poder religioso, político e econômico, o museu foi instrumento de subjugação, conquista e doutrinação na mão dos "vitoriosos da história", mas também ainda que de maneira insurgente vale pontuar que ele foi um importante meio de organização e de protesto de alguns contraventores de seu período, servindo de plataforma e vitrine para um novo Paradigma.

\subsubsection{3 ${ }^{\circ}$ Paradigma: Ciência Racional - Século XV- XIX}

Após dois paradigmas que mesmo que de formas diferentes evocavam respectivamente o mítico e o sagrado, neste terceiro Paradigma começaram a surgir questões acerca das explicações divinas. Galileu Galilei (1564 - 1642), por exemplo, questionou a lógica cristã sobre a centralidade do universo. Decartes (1596 - 1650) começa a buscar respostas para o que não se encaixava em nenhuma das teorias anteriores e constrói certezas através das incertezas. O conhecimento passa a ser fundamentado no pensamento racional, baseado na busca pela razão e por consequência, da verdade. E a razão provém de testes, que se dão por 
meio do experimento e da submissão da explicação à prova (informação verbal) ${ }^{9}$. Este Paradigma, também conhecido como científico-moderno, buscava romper com as tradições e crenças, substituindo-as pela ciência e a técnica.

Essencialmente desenvolvido no seio das ciências naturais, o pensamento disciplinar e racional usava a ciência a serviço do homem, a explicação e previsão de todos os fenômenos estão ao seu alcance, e pela primeira vez a noção de felicidade não se encontrava em outras mãos que não nas do próprio ser humano. É no decorrer deste paradigma que movimentos como o Renascimento e o Humanismo florescem e dentre outros fatores, Castro (2009, p. 47) destaca respectivamente o "resgate da cultura helênica" e a "recuperação dos modelos artísticos, literários e científicos da Antiguidade greco-latina" como pontos marcantes destes movimentos que vieram, sobremaneira, para afirmar a independência do espírito humano.

A autora também situa que as coleções dos humanistas e mecenas do Renascimento passam a compor salas em que pudessem ser "admiradas e estudadas por artistas e eruditos, catalogadas e inventariadas por especialistas que elaboravam inventários descritivos das coleções”. Ademais, Castro (2009) nos apresenta as contribuições e características de outro relevante movimento deste paradigma, o iluminismo:

Pode-se dizer um período de descoberta do homem na condição de homem, o que significa uma reafirmação de todas as categorias do humano. O movimento iluminista coloca o homem no centro de todas as preocupações artísticas, filosóficas e morais, que se torna preocupado em guardar testemunhos do passado e em resgatar sua genealogia social e cultural (CASTRO, 2009, p. 47).

Impulsionada pelo efervescente contexto exposto deste novo paradigma, a sociedade se pôs em movimento em busca de descobertas: novas teorias, novas experimentações, novos horizontes de possibilidades e foi através das grandes navegações que as coleções principescas iniciadas no paradigma anterior foram ampliadas formando as grandiosas galerias palacianas e que também se fez surgir um novo e importante ator nesta trajetória do universo museal: os gabinetes de curiosidades.

\footnotetext{
${ }^{9}$ Zanirato, aula dada na disciplina Filosofia da Ciência, do curso do Programa de Pós Graduação em Mudança Social e Participação Política, EACH-USP, no decorrer do $1^{\circ}$ semestre de 2016.
} 
Nestes recintos haviam fósseis, animais empalhados, plantas exóticas, inventos, minerais, obras de arte e objetos raros (muitos de fonte no mínimo duvidosa, como rabos de sereia e o cabelo de sansão) (SUANO, 1986). Essas curiosidades, em sua maioria provindas de terras distantes e exibidas quase sempre de forma caótica, eram como troféus de seu colecionador, visto que, a presença dele era imprescindível para alguma compreensão do significado e origem das peças ali expostas.

Alguns gabinetes, formados por estudiosos, dispunham de uma grande variedade de plantas, objetos e animais exóticos, que reunidos em um ambiente, buscavam simular a natureza de outros lugares, sendo usados tanto para deleite do colecionador quanto para fins acadêmicos (SUANO, 1986, p. 21). Este último perfil de colecionador conhecido como antiquaries ${ }^{10}$ [antiquários] (CHOAY, 2017) eram eruditos cuja pesquisa meticulosa e paciente leva a diante a abordagem inaugural dos Humanistas, "os antiquários acumulavam em seus gabinetes não apenas medalhas e outros fragmentos do passado, como se dizia então, mas também, sob forma de compilações e portfolios, verdadeiros dossiês, com descrições e representações figuradas da antiguidade" (CHOAY, 2017, p. 65).

Além das grandes navegações, o Renascimento teve um papel central para a trajetória do Museu. Por meio de comerciantes, integrantes da burguesia em ascensão, banqueiros e príncipes que financiavam tanto a busca por relíquias e tesouros da antiguidade quanto a própria criação de obras de arte, este período apresentou inúmeras contribuições que transcenderam o seu tempo. Suano (1986) nota que:

\begin{abstract}
Os príncipes das casas reinantes europeias, felizmente, não satisfeitos com os tesouros que obtinham de todas as partes do mundo com que comerciavam e dos novos mundos que descobriam (é a época dos descobrimentos das terras além-mar), ainda financiavam os artistas contemporâneos (Botticelli, Leonardo da Vinci, Michelangelo, Rafael, Cellini, Palladio, Tintoretto, Fra Angelico, etc.) e incorporavam boa parte dessa produção em suas já magnificas coleções. (SUANO, 1986, p. 17)
\end{abstract}

É inegável hoje a importância histórica e artística de tais sujeitos e suas produções, sobretudo nos campos da escultura, arquitetura e pintura que representam atualmente grande destaque

\footnotetext{
${ }^{10} \mathrm{Em}$ sua primeira conotação no Dictionnaire de l'Académie française, a palavra antiquaire designa aquele que é "especialista no conhecimento de objetos de arte antiga e curioso deles" (CHOAY, 2017, p. 62).
} 
nos acervos de diversos museus. Diante deste contexto de efervescência social e cultural, intelectual e artística, derivadas de importantes movimentos como o Renascimento, Humanismo e Iluminismo (CHOAY, 2017), o Paradigma da Ciência Racional representou uma guinada positiva no universo museológico.

De certa maneira, as galerias palacianas e os gabinetes de curiosidades enquanto forma de apresentação e especialmente de composição do acervo, de fato deram origem à instituição Museu como a conhecemos hoje, mas tanto os gabinetes como as galerias ainda figuravam majoritariamente dentro dos meios fechados, acessíveis apenas a familiares e amigos do colecionador, inacessíveis à população em geral.

A ampliação do acesso às coleções foi lenta. Primeiro foi a Igreja Católica Romana que vendo a sua soberania em declive decidiu abrir o seu acervo como forma de usar a cultura em defesa, manutenção e propagação de suas crenças. Havia também os pensadores e estudiosos que mesmo perseguidos pelo legado do paradigma Judaico-Cristão e sofrendo com a Inquisição defendiam o uso do Museu como uma sede aberta do pensamento científico.

Fato é que, devido ao ciúme de seu colecionador, da fragilidade das coleções quanto a roubos e da suposta 'falta de postura' do público, o acesso às coleções era restrito a poucos (SUANO, 1986). Foi somente no final do século XVIII com a revolução burguesa ${ }^{11}$ que usando o Museu de acordo com a sua necessidade de se firmar como classe dirigente, $\underline{\text { não }}$ mais o privilégio de alguns, as coleções, principalmente as de origem principesca, tornam-se públicas. Ainda que por motivações essencialmente políticas, este paradigma viu nascer alguns dos principais museus ainda contemporâneos como os Museus do Vaticano (1506), Museu Britânico (1753), Museu do Louvre (1793), Museu Real (1818) ${ }^{12}$ (Brasil Colônia) e Museu do Prado (1819), entre outros. O final do século XIX e o início do século XX, ou seja, um momento de transição entre paradigmas chega a ser apontado por alguns autores como a "era dos museus" devido ao surgimento de muitas instituições museais, especialmente na Europa.

\footnotetext{
${ }^{11}$ Para saber mais sobre a Revolução Burguesa e a abertura dos museus ao público, consulte SUANO, Marlene. O que é museu, 1986.

${ }^{12}$ A mais antiga instituição científica do Brasil, o atual Museu Nacional - UFRJ está localizado na Quinta da Boa Vista, Rio de Janeiro e em 2018 foi acometido por um grande incêndio que destruiu grande parte de seu acervo. Para conhecer mais acesse: http://www.museunacional.ufrj.br/
} 
Podemos observar neste $3^{\circ}$ Paradigma que sua essência questionadora e por vezes conflituosa, ainda em embate constante com as raízes de seu paradigma antecessor se traduz na ambiguidade das respostas consolidadas do Quadro 3. Mas de fato, o homem vivia uma verdadeira revolução do olhar. O desenvolvimento sociológico do iluminismo, as crises social e moral do fim da Idade Média e o nascimento da sociedade industrial - processos que tiveram como grande marco a Revolução Francesa (1789-1799), mudara completamente a maneira como o homem encarava o mundo. A doutrina filosófica, sociológica e política do Positivismo idealizada por Auguste Comte e John Stuart Mill surge no início do século XIX, ou seja, no início do fim deste paradigma para selar esta mudança.

As descobertas que as grandes navegações trouxeram, o Renascimento que permitiu a redescoberta do mundo e do homem a partir de uma visão mais naturalista e humanista, colocaram a adiante o espírito científico culminando em um universo de possibilidades que legaram um novo mundo repleto de invenções como a locomotiva, o navio a vapor, a fotografia, o telefone, os carros, o avião, a televisão, os computadores e a internet, e um mundo de descobertas como a teoria da relatividade e inúmeras outras teorias, inovações que mudaram para sempre o nosso modo de viver e de se relacionar com o mundo.

Quadro 3: Principais características $3^{\circ}$ Paradigma: Ciência Racional - Século XV- XIX

O que é conhecimento? A busca pela verdade por meio do pensamento racional

O que é museu? Grandiosas Galerias Palacianas e os excêntricos Gabinetes de Curiosidades

A que se destina? Ao deleite do colecionador e ao estudo das Artes e Ciências

A quem se destina? Quem o frequenta?

Artistas, eruditos e estudiosos

Fonte: Elaboração própria, 2018.

Vale neste momento final de apresentação e análise dos paradigmas antecessores ao que estamos vivenciando e construindo, ressaltar a reflexão de que a transição de um paradigma para o outro não anula completamente o anterior (SANTOS, 2006). E é por isso que, mesmo após a sequência de paradigmas apresentada e na iminência de um novo, podemos encontrar 
facilmente elementos da mitologia que sobrevivem na nossa cultura até os dias de hoje, que vislumbramos a importância e influência da religião na nossa sociedade e que nomes como os de Sócrates, Aristóteles, Newton, Darwin, Leonardo Da Vinci, Lutero, Durkheim, Lavoisier, Adam Smith, entre outros figuram em livros didáticos em escolas ao redor do mundo. Assim como é por este mesmo motivo que hoje existem diversos museus, que, tanto em sua filosofia quanto em seu próprio acervo possuem frutos ou legados destes paradigmas.

Quase como um presente que nos foi dado por estes legados, o final do $3^{\circ}$ paradigma culminou semeando a ideia de um Museu Público, ainda que longe do significado do que hoje compreendemos como Público. Com inúmeras restrições, desde horários, cobrança de ingressos e a necessidade de cadastro prévio do interessado na visitação, o museu do final do século XIX não era convidativo, e nem pretendia sê-lo. Em um ambiente não mais pertencente à aristocracia, mas que não espelhava nada além dela mesma, o Museu aguardaria mais algumas décadas e, por um novo Paradigma, para transformar-se de um Museu Público para um Museu a serviço do público, com todas as nuances que este último carrega e que serão apresentadas no próximo Capítulo. 


\section{UM PARADIGMA EM CONSTRUÇÃO: UMA NOVA REALIDADE MUSEOLÓGICA}

Estamos em transição, a ciência está sendo questionada. Ela continua sendo de vital importância, mas não mais uma lei, deixando de ser a única explicação possível. Apesar de Einstein criar uma fórmula tão exata, lembremo-nos das palavras de Sheakspeare "existem mais coisas entre o céu e a Terra do que a nossa vã filosofia tem conhecimento”. E este conhecimento não é mais tido como certo, neste Paradigma ainda em construção, o conhecimento científico é reconhecido como passível de falhas, provisório e interdisciplinar. Duarte (2013, p. 105) nota que "a certeza e a confiança, antes depositadas na superioridade do pensamento racional", pertencentes o paradigma da Ciência Racional, "são agora trocadas pela percepção de que o conhecimento é sempre e inevitavelmente uma construção histórica e social".

Também conhecido como Paradigma da pós-modernidade, ele questiona o modo de vida autodestrutivo voltado ao desenvolvimento a qualquer custo, ao mesmo tempo em que o venera. Assume que os problemas são mais complexos e que por isso não seria uma única área do conhecimento que daria conta de supostamente resolvê-los. A interdisciplinaridade antes vista como uma fraqueza para o conhecimento científico, agora é encarada como um trunfo para as ciências, ainda que não saibamos muito bem como aplicá-la.

Nesta nova conjuntura alguns autores destacam-se, dentre os quais Edgar Morin, Boaventura de Souza Santos e Rubem Alves. As teorias que emergem deste paradigma adquirem um caráter que talvez se aproximem do que Morin (2000) chama de scienza nuova. De uma característica mais contemplativa, este novo tipo de ciência não apresentaria pretensões de controlar a natureza, seria mais humana.

No início da transição do paradigma da Ciência Racional para este que estamos presenciando, diversos museus foram criados. Como dito anteriormente, eles já não pertenciam à aristocracia, mas agora eles também já não tinham mais serventia política para a burguesia; o Museu então estagnou-se. E assim como a ciência ele também começa a ser questionado, seus fundamentos, concepções e a sua real função dentro da sociedade são colocados em "xeque". Quase que como reivindicando-o, a sociedade se une em torno do Museu, criando 
organizações que objetivam reerguer e repaginar esta instituição, que agora sob o manto de uma Nova Museologia (movimento que será aprofundado mais adiante) é tratado como patrimônio coletivo dos povos.

\section{$3.14^{\circ}$ PARADIGMA ATUAL - SÉCULO XX...}

Após apresentar os paradigmas Greco-Romano, Judaico-Cristão e Ciência Racional, chegamos ao $4^{\circ}$ Paradigma, ainda sem um nome próprio, mas que mostra a sua face questionadora, onde todo e qualquer conhecimento é posto a prova, desta vez sob os olhares atentos da sociedade. As verdades se apresentam sim, mas como provisórias, quase que ansiando por sua contraprova.

E é sob a luz deste novo paradigma ainda em construção e repleto de questionamentos que se inserem as contribuições desta pesquisa, situada em um programa de Pós-graduação interdisciplinar, fruto das características do paradigma vigente. Também repleta de questionamentos e incertezas, e que mesmo após a sua concretização se manterá aberta e em constante (re)construção.

Nesta trajetória, mediante a estagnação e o questionamento das instituições museológicas, no momento da transição entre o $3^{\circ}$ e o $4^{\circ}$ paradigmas, o Museu viu-se, de certa forma, encurralado, de um lado a história lhe apontava os braços da elite, que o reivindicava usando como justificativa sua herança histórica, mas ao preço de sua exclusividade, por outro lado, as classes sociais menos privilegiadas, até então totalmente à margem deste universo, criticavam-no, ao mesmo tempo em que começavam a acenar com propostas inovadoras de abertura e interação, que caso aceitas, mudariam drasticamente o universo museal. Duarte (2013) nos apresenta o contexto histórico/social ao que este impasse estava inserido:

Em maio de 1968, um grupo de profissionais de museus organizava-se espontaneamente, em Paris, para contestar os museus, considerados "instituições burguesas". Os estudantes chegam a reclamar a supressão de todos os museus e a dispersão das suas coleções por espaços da vida quotidiana. O seu slogan é "La

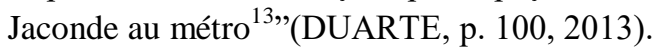

\footnotetext{
13 Tradução: "A Jaconde/Gioconda ao metrô", em uma alusão de que a famosa obra de arte do pintor Leonardo da Vinci, localizada no Museu do Louvre, deveria ser exposta no metrô, as vistas de todos que por ali passassem.
} 
Além mar, ecoavam-se, ainda que acima da linha do Equador, os mesmos anseios:

Nos Estados Unidos da América, alguns artistas organizavam-se para rejeitar a arte e os museus. As novas linguagens e expressões artísticas demonstravam uma não-empatia pela instituição e recorriam à utilização de espaços alternativos, como grandes armazéns vazios, numa aproximação a um modelo de anti-museu. Em simultâneo, em diversos países europeus, os índices de visitantes dos museus caiam e tornava-se evidente que a instituição se tinha transformado em pouco mais do que um depósito lúgubre de objetos (DUARTE, p. 100, 2013).

Duarte (2013) refere-se às manifestações de dentro do universo museal, mas estamos falando de um contexto muito maior, resultado de uma série de desdobramentos políticos e filosóficos iniciados em Paris. Em meio a lutas pelos direitos civis, greves por melhores condições de trabalho e Guerras como a do Vietnã, o ano de 1968 que ficaria conhecido como o ano da Revolução Cultural ${ }^{14}$, representou o ápice da "revolução do olhar" introduzida lá atrás pelo terceiro paradigma. Agora o homem investido de seu olhar questionador, começa indagar a ele próprio e suas ações.

O contexto social de intenso questionamento e mudança que abarcou a década de 1960, não permitiu que o museu passe ileso por esse período, "a inserção do museu nesses movimentos sociais e a exploração dinâmica das suas coleções exigia uma verdadeira metamorfose da instituição" (DUARTE, p. 100, 2013). Nas duas décadas seguintes, paralelamente à crise econômica, intensificou-se o questionamento do papel dos museus na sociedade, eram tempos que clamavam por uma nova postura museológica.

A resposta dos museus às ofensivas feitas pela elite e pelas classes sociais menos privilegiadas, não ocorreu de maneira harmoniosa e muito menos uniforme, porém as diversas investidas feitas pelas classes menos favorecidas obtiveram resultados; novas perspectivas inauguram caminhos. E Finalmente, dando voz ativa (ainda que, em territórios delimitados) àqueles que por muito tempo foram negligenciados os museus voltam-se ao trabalho árduo de transformar-se em um vetor cultural acessível a todos, removendo uma letargia que o dominava já há algum tempo.

\footnotetext{
${ }^{14}$ Para saber mais sobre os acontecimentos de maio de 1968 e a Revolução Cultural, consulte "Esqueça 1968" do autor Daniel Cohn-Bendit (2008) e para compreender os impactos em um contexto brasileiro, consulte "1968 o ano que não terminou" do autor Zuenir Ventura (1989).
} 
Faz-se agora necessária uma pausa para explicar em que momento e sob quais circunstâncias o Museu aceita algumas propostas inovadoras e começa a transpor a barreira de instituição meramente pública, para uma instituição a serviço do desenvolvimento da sociedade.

Grande parte desta mudança se deve ao surgimento da Museologia enquanto campo científico, visto que "Museologia e Museus têm caminhos entrelaçados, responsabilidades recíprocas e cumplicidade no que tange a função social” (BRUNO, 2006, p. 7). Com uma longa história de inexistência enquanto disciplina, mas de existência enquanto prática, a Museologia recebeu contribuições de diversas áreas do conhecimento: Antropologia, Sociologia, História, Arqueologia, Filosofia, Educação etc, porém, com o passar do tempo, percebeu-se a necessidade de firmá-la como um campo independente, fato que se torna evidente no Seminário do ICOM de 1972, que tratava da formação profissional para museus. No entanto, este relacionamento antigo com outras áreas não foi abandonado (apesar de períodos conturbados na relação entre Museólogos e Antropólogos) e fez com que ainda hoje a interdisciplinaridade seja a base da Museologia.

Com o intuito de compreender esta transformação, voltaremos a revisar fontes históricas e desta vez de forma cronológica (por que não?), apresentando momentos e documentos, que proporcionaram dentro do paradigma atual, as mudanças mais recentes no universo dos museus. Para Cury (2014), alguns momentos foram particularmente essenciais para que a Museologia se desenvolvesse e alcançasse o status que possui hoje. E como ponto de partida, destacamos a criação em 1976 do ICOFOM - Comitê Internacional para a Museologia, pois foi por meio de suas reuniões, produções, esforços e incentivos, que os diálogos entre o universo museal (com seus acadêmicos e entusiastas) e a sociedade como um todo começam a caminhar de fato por uma via de mão dupla.

A partir de sua criação, o ICOFOM passou a ser o maior e mais importante fórum de discussão e estudo sobre a teoria museológica (CURY, 2014). Formado por membros de todos os continentes (ainda que no início as nacionalidades fossem excessivamente europeias) que se encarregam de pesquisar, estudar e disseminar as bases teóricas da Museologia enquanto disciplina científica independente e analisando criticamente as principais correntes da Museologia contemporânea. Criado dentro do ICOM, de forma paralela tanto o Conselho Internacional de Museus quanto o Comitê Internacional para a Museologia trabalham para o desenvolvimento respectivo e interligado dos museus e da museologia, sendo o ICOFOM 
responsável por organizar encontros científicos e acadêmicos em diferentes países com o intuito de assegurar que as diversas realidades sejam representadas em seus encontros.

O comitê é um fórum internacional para o debate museológico. Em seu sentido mais amplo, a Museologia trata do enfoque teórico sobre qualquer atividade humana, individual ou coletiva, relacionada à preservação, interpretação e comunicação de nossa herança cultural e natural, e sobre o contexto social em que ocorre a relação específica entre o homem e o objeto. Embora o campo do Museologia seja muito mais amplo que o próprio estudo de museus, seu foco principal permanece nas funções, atividades e o papel dos museus na sociedade, como depositórios da memória coletiva. ICOFOM estuda também as várias profissões que atuam no museu. Um tópico importante é o inter-relacionamento entre a teoria e a prática. (ICOFOM, 2019)

O comitê também é responsável pela produção e divulgação de um vasto e importante material teórico, a ISS - ICOFOM STUDY SERIES. Esta Série de Estudos do ICOFOM tornou-se com o passar dos anos a maior coleção bibliográfica de museologia do mundo.

Os encontros científicos e acadêmicos mediados pelo ICOM e pelo ICOFOM possuem cada qual uma temática específica. Dentre muitos, seguiremos os apontamentos de Cury (2014) e faremos um recorte, pontuando alguns destes encontros cujo o debate por ele iniciado contribuiu para a expansão de significados tanto do Museu quanto da Museologia, principalmente no que diz respeito a função social dos museus neste novo paradigma, objeto de estudo central desta pesquisa.

- 1977, Leningrado, Rússia - instalação do Comitê.

Apesar de sua criação oficial em 1976, foi somente no ano seguinte durante a conferência trianual do ICOM que o ICOFOM passa de fato a existir e a organizar diversos encontros. A produção teórica fruto das discussões de seus membros é publicada na MuWoP/DoTraMMuseological Working Paper/ Documents de Travail sur La Muséologie ${ }^{15}$, com periódicos entre 1980-1982.

- 1978, Nieborów, Polônia - $1^{\circ}$ encontro anual e 1979, Torgiano, Itália - $2^{\circ}$ encontro anual

\footnotetext{
${ }^{15}$ A abreviação e a denominação em inglês e em francês, gerando um "nome duplo" ocorreu devido a natureza bilíngue do ICOM.
} 
Nestes dois primeiros encontros, os resultados foram um tanto desalentadores para a base teórica da museologia, já que "as interpretações de um mesmo conceito foram muito diferentes" (KLAUSEWITZ, 1997, apud CURY, 2014, p. 47).

- $\quad$ 1980, México - Museologia, uma ciência em formação

Após a desordem dos primeiros encontros, neste segundo momento, fez-se necessária uma temática voltada à ideia de posicionar a museologia como disciplina cientifica e ciência. Para tanto a MuWop ao invés de se impor, estampou em sua capa a dúvida com a seguinte pergunta: Museologia - ciência ou apenas um trabalho da prática do museu? (Figura 2).

Figura 2: Capa da Revista MuWoP, $n^{\circ} 1$ de 1980

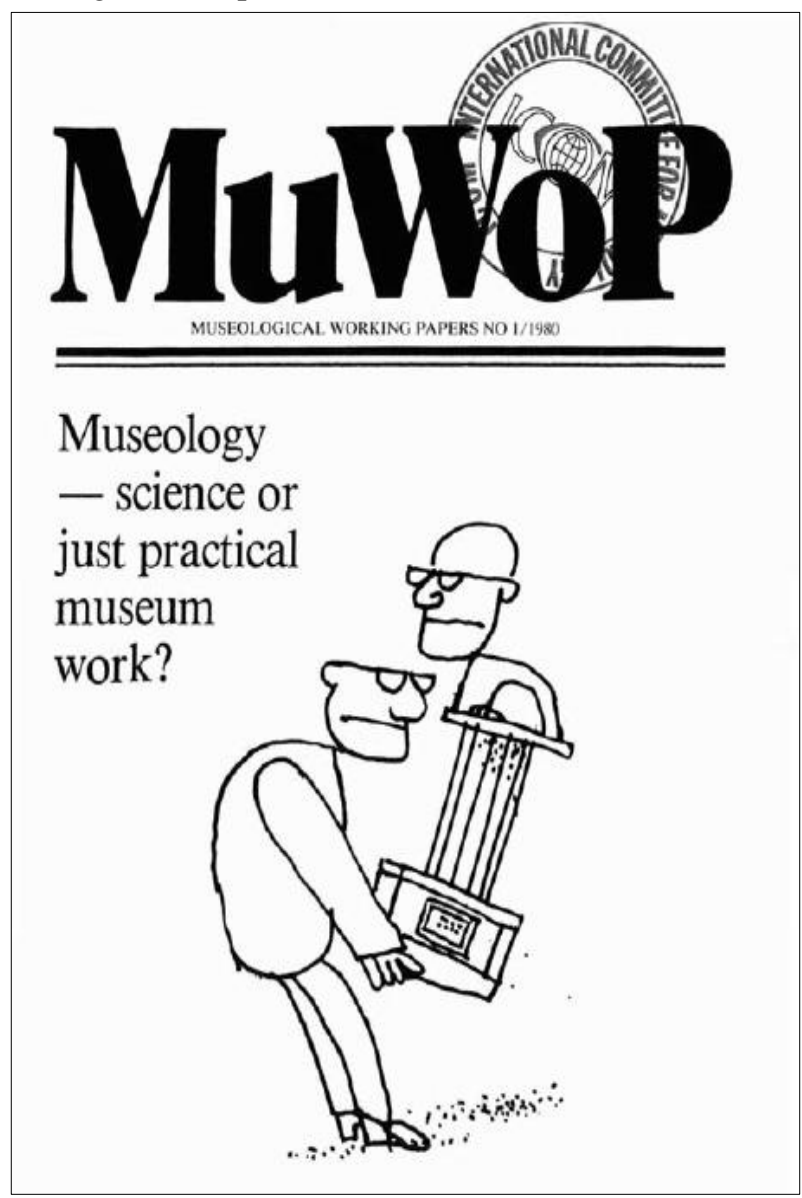

Fonte: network.icom.museum

Podemos observar que a figura do homem que parece representar a Museologia, carrega um objeto que disposto em um expositor e com uma placa de identificação aparentemente trata-se 
de um objeto museológico, precisamente uma estátua que esteticamente faz alusão a uma esfinge, cuja face reflete a da própria Museologia. Um olhar atento vislumbra uma Museologia sem a parte de cima da cabeça, logo abaixo da Esfinge, que conhecida pela famosa frase decifra-me ou devoro-te, conhece-te a ti mesmo parece ter acabado de fazer a pergunta que estampa a capa, e sem obter resposta devorou a parte pensante da Museologia. Tal metáfora é posta em um momento de muitas dúvidas da Museologia sobre a própria Museologia, clamando por uma resposta que esclareça de uma vez por todas o seu objeto de estudo.

Cury (2014) lembra que, nesse encontro foram propostas duas teorias sobre o objeto de estudo da Museologia:

$\checkmark$ “a relação específica entre homem e a realidade” de Zbynek Z. Stránský e Ana Gregorová;

$\checkmark$ “o fato museal” a "relação profunda entre o homem e o objeto" de Waldisa Russio Camargo Guarnieri (Brasil);

- 1981, Estocolmo, Suécia - Museologia e interdisciplinaridade

Como salientamos anteriormente, a interdisciplinaridade característica deste novo paradigma que vivemos é a base da Museologia que depende de uma diversidade de áreas do conhecimento para dar conta de seus estudos. Neste encontro o debate se deu sobre a importância da interdisciplinaridade como método de ação para a prática nos museus, para a pesquisa em Museologia e para a formação e capacitação do profissional (CURY, 2014).

Inicialmente proposto como "A ciência multidisciplinar na Museologia, Pesquisa Básica em Museologia e Ciência Aplicada" (CERÁVOLO, 2004, p. 324) podemos observar na Figura 3, que este debate ainda estava em seu início, e a interdisciplinaridade representada na capa da revista pela figura do homem (que precisava de muitos braços para dar conta de várias atribuições de diferentes áreas) é observada com um olhar medroso de uma criança, que a direita da figura do homem, apequenada, parece simbolizar o futuro ou as gerações futuras, vislumbrando com certo receio os desafios da interdisciplinaridade. 
Figura 3: Capa da Revista MuWoP, nº 2 de 1981

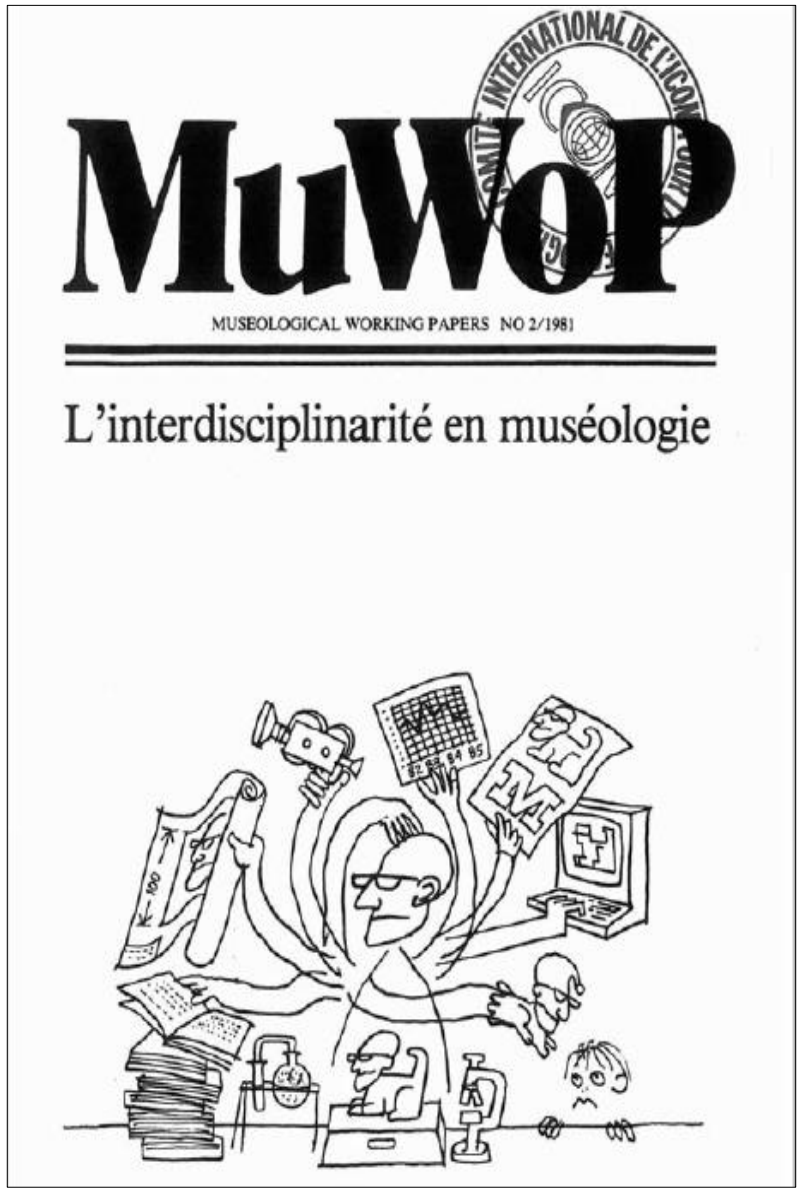

Fonte: network.icom.museum

Foi durante este mesmo ano que Waldisa Russio reformulou a sua definição de fato museal para: "a relação profunda entre o Homem, sujeito que conhece, e o Objeto, parte da realidade à qual o Homem também pertence e sobre a qual tem o poder de agir" (GUARNIERI, 1981, apud, CURY, 2014, p. 48).

- 1982, Paris, França - O sistema da Museologia e interdisciplinaridade

Por divergências em torno do tema proposto, no ano de 1982 a discussão não aconteceu. Mas graças ao empenho pessoal de Georges Henri Rivière o encontro resultou em uma avaliação sobre o papel do ICOFOM, fato esse que que iníciou uma nova fase do Comitê.

- 1983 , Londres, Inglaterra - Metodologia da Museologia e formação profissional 
O encontro ocorrido em Londres trouxe respostas a algumas dúvidas que giravam em torno da seguinte questão: tendo em vista como se dá a interdisciplinaridade dentro da Museologia, qual a natureza do conhecimento museológico?

Nesse momento também ocorre uma pausa. O modelo proposto por Z. Z. Stránský no encontro de 1980 fora exaustivamente debatido, chegando a uma proposta de divisão dentro da área de estudo da Museologia:

$\checkmark$ Museologia Geral;

$\checkmark$ Museologia Especial;

$\checkmark$ Museologia Aplicada.

Outro fato importante desta mesma data é a interrupção da publicação MuWoP/DoTraM, que foi substituída posteriormente pela série de estudos ISS - ICOFOM STUDY SERIES. Podemos indicar que esteticamente falando, a figura 4 exibe uma grande mudança em sua apresentação, diante do que observamos nas figuras 2 e 3. Sem imagens, com fonte simples e cor única, a Revista aposta em seu conteúdo, organizado quase como um diário de registros dos encontros promovidos pelo ICOFOM. 
Figura 4: Capa da ISS, $n^{\circ} 1$ de 1983

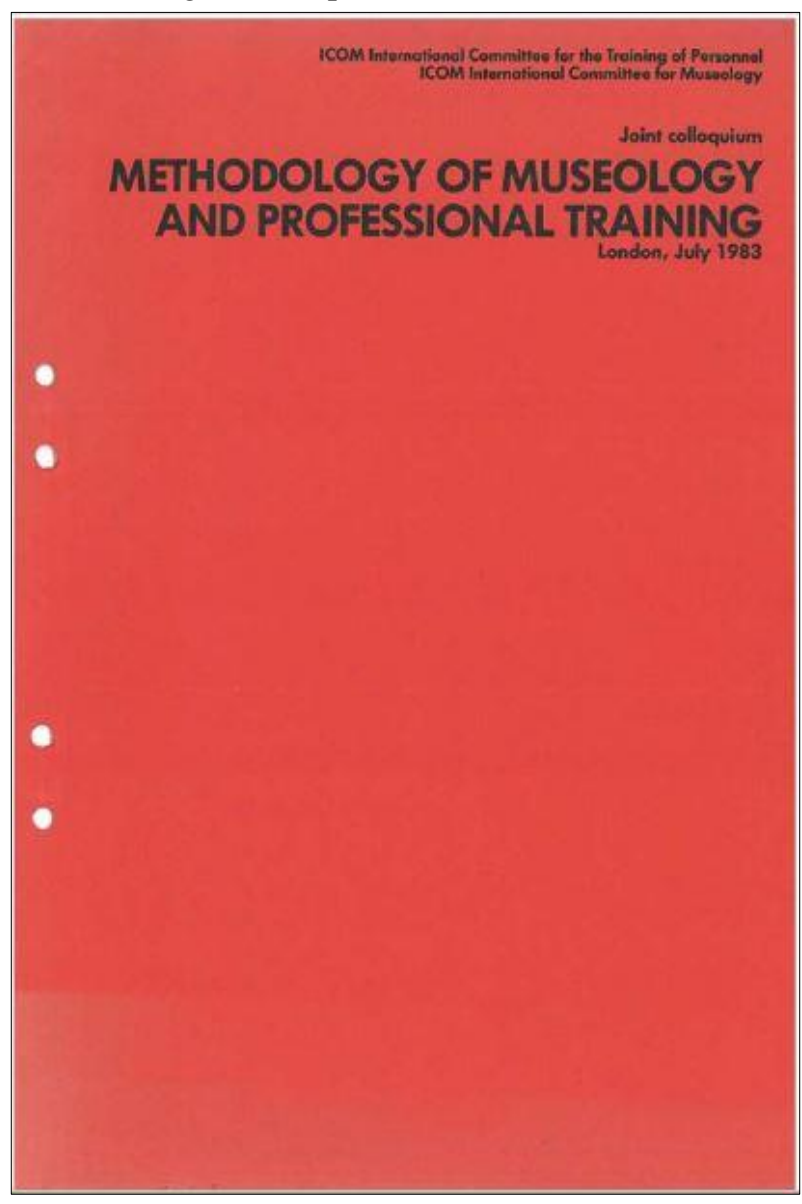

Fonte: network.icom.museum

Neste mesmo encontro foi abordado outro tema: "Museu, território, sociedade: novas tendências/novas práticas", que discutia conceitos de território e territorialidade, memória, desenvolvimento, cotidiano, comunidade, identidade e ecologia.

- 1984 , Leiden, Holanda - Coletar hoje para o amanhã.

A seletividade e os critérios de seleção de objetos para um museu foram abordados, valendose da premissa de que "o objeto não vale por si só e sim por seus valores culturais", considerou-se também que "os objetos museológicos têm como atributos valores sociais, religiosos, estéticos, artísticos, afetivos, científicos, políticos e ideológicos" (CURY, 2014, p. 51), indo muito além de critérios como a aparência, valor monetário de seu material ou a raridade do objeto. 
De muitos modos, o museu é uma instituição que constrói definições de valor. O que decide pesquisar ou ignorar, os bens culturais que seleciona para conservar e expor em detrimento de outros que negligencia, o modo como concretiza essas tarefas e as justifica, com o auxilio de quem, todas estas opções constituem um conjunto de decisões que se tornam matérias merecedoras de interrogação (DUARTE, 2013, p. 112 e 113).

Esta temática, aparentemente superficial, envolve questões profundas. O Museu é um lugar de disputas e conflitos de poder, a todo momento decide-se quem irá frequentá-lo e consequentemente quem não o frequentará, quem ou o que será exposto. Fundamentalmente, o Museu é um local de escolhas, e os critérios destas escolhas ficaram mais coerentes com a sua função social após os debates feitos durante esse encontro.

- 1985, Zagreb, Croácia - Originais ou substitutos em museus, e

- 1986, Buenos Aires, Argentina - Museologia e identidade

Em Zagreb, a temática de discussão mais conceitual que refletiu sobre a relação homemobjeto, abordando a questão da autenticidade e da dicotomia original/substitutos nos museus.

No ano seguinte, dez anos após a criação do ICOFOM o encontro acontece pela primeira vez em solo Sul-Americano e levantou uma temática ainda extremamente contemporânea, que aprofundava reflexões sobre o papel dos museus e do patrimônio cultural na (re)construção da identidade cultural (ISS, n. 10 e 11, 1986).

- 1987, Helsinque-Espoo, Finlândia - Museologia e museus

Chegamos enfim ao encontro que consagrou o processo de transformação dos museus como instituição pública para uma instituição a serviço do desenvolvimento da sociedade, questão sublinhada no início do Capítulo 3.

Abordando o crescimento do fenômeno museus e avaliando a relação da instituição com a disciplina, num processo de transformação de tempo e espaço. Cury (2014) destaca algumas propostas debatidas neste encontro, das quais destacamos:

$\checkmark$ o deslocamento de ênfase do objeto para o público e a comunidade;

$\checkmark$ o alargamento do conceito de objeto de museu (abrangendo o imaterial);

$\checkmark$ abertura à tendência para a conservação em seu contexto; 
$\checkmark$ descentralização dos museus (propõe-se a criação de pequenos museus);

$\checkmark$ mudança do enfoque das exposições, de mostras de acervos para exposições temáticas;

$\checkmark$ aperfeiçoamento administrativo de museus.

- 1988, Hyderabad-Varanashi - Nova Delhi, Índia - Museologia em países em desenvolvimento - ajuda ou manipulação?

O encontro refletiu sobre o papel social dos museus nesses países. Retomou-se a questão da identidade cultural local, considerando-se as necessidades específicas dos países em desenvolvimento.

Fruto desta discussão avaliou-se que tanto os museus quanto a Museologia são "promotores de desenvolvimento e mudanças sociais, pois agem nos âmbitos cultural e educacional” (ISS, n. 16, 1988).

-1989, Haia - Museologia e futurologia

Com uma temática ambiciosa a década dos anos 1980 chega ao fim com um exercício de ponderação sobre o que se pode prever do futuro em relação à Museologia e aos museus. Estiveram na pauta das discussões os seguintes tópicos: o que coletar hoje para deixar para o futuro? como os conceitos evoluirão e se haverá um espaço social a ser ocupado pelos museus futuramente? (ISS, n. 16, 1989).

\section{- 1990 - criação dos sub-comitês do ICOFOM}

Destacamos agora um momento importante para a "independência" dos estudos em Museologia para a realidade latino americana.

Durante a conferência realizada em Haia, no ano anterior, o ICOFOM deliberou sobre como regionalizar seus trabalhos, atendendo às políticas de descentralização e de regionalização do ICOM estipuladas no Programa Trienal 1989- 1992. Dentre as resoluções constavam a criação de grupos regionais na África, Ásia e Oceania, Europa, América do Norte e a região da América Latina e Caribe. Como representantes latino-americanas, Nelly Decarolis (Argentina) e Tereza Scheiner (Brasil) foram encarregadas de organizar o grupo de trabalho para a sua região. Em novembro de 1990, reunidas no Rio de Janeiro, Brasil, planejaram e 
programaram a criação e implementação do grupo regional - que desde então denominou-se ICOFOM LAM.

Este subcomitê Regional do ICOFOM (ainda atuante ${ }^{16}$ ) dedica-se ao estudo, discussão e produção de teoria museológica na América Latina e no Caribe. Desde seu início, os objetivos do ICOFOM LAM foram promover e documentar o trabalho de investigação da teoria museológica latino-americana, permitindo assim uma maior participação de seus membros através da organização de encontros anuais nos países da região; da produção de documentos teóricos; de discussões científicas; de intercâmbio profissional; e da edição de publicações nos idiomas espanhol e português.

Com quase três décadas de existência, os acadêmicos e profissionais de museus do ICOFOM LAM são responsáveis por uma necessária adequação das discussões à realidade latino americana. Estamos falando do momento inicial onde o debate, oficialmente validado, deixa de ser feito exclusivamente no eixo América do Norte - Europa. Um passo importante para a Museologia e para os museus latinos e especialmente sul americanos, que a partir da criação deste sub-comitê passaram a ter voz em temáticas próprias para a sua realidade e desafios.

No decorrer dos anos 90, o que se segue são temáticas diversificadas que tratam de questões pontuais e de suma importância para o crescimento da Museologia e consequentemente dos museus: 1990, Livinsgstone-Mfuwe, Zambia - Museologia e o meio ambiente; 1991, Vevey, Suíça - A linguagem das exposições; 1992, Quebec, Canadá - Simpósio de pesquisa museológica; 1993, [s.I] - Museu, espaço e poder; 1994, Pequim, China - Objeto documento?; 1995, Stavanger, Noruega - Museu e comunidade; 1996, Rio de Janeiro, Brasil - Museologia e arte; 1997, Paris, França - Museologia e memória; 1998, Melborne, Austrália - Museologia e mundialização; 1999, Coro, Venezuela - Museologia e filosofia.

É durante este período de efervescência de debates, com temáticas plurais e inovadoras que Peter Van Mensch comenta que a Museologia:

\footnotetext{
${ }^{16}$ Para informações atuais, consultar: http://network.icom.museum/icofom/L/1/ ou https://www.facebook.com/icofom.lam.oficial/
} 
[...] é uma abordagem específica do homem frente à realidade, cuja expressão é o fato de que eles selecionam alguns objetos originais da realidade, inserindo-os numa nova realidade para que sejam preservados, a despeito do caráter mutável inerente a todo objeto e da sua inevitável decadência, e faz uso deles de uma nova maneira, de acordo com suas próprias necessidades (MENSCH, 1994, p.12).

Retomando o questionamento proposto sobre o que é museologia, e aprofundando a questão do objeto de estudo da museologia, Mensch $(1994$, p.3) propõe quatro tendências sobre o que esta área do conhecimento abrange, justamente fundamentando a sua análise na produção anteriormente apresentada, organizada e escrita do ICOFOM:

$\checkmark$ Museologia como estudo da finalidade e organização dos museus;

$\checkmark$ Museologia como estudo da implementação e integração de um certo conjunto de atividades, visando à preservação e o uso da herança cultural e natural: dentro do contexto da instituição museu e independente de qualquer instituição.

$\checkmark$ Museologia como o estudo dos objetos museológicos

$\checkmark$ Museologia como o estudo da musealidade como uma qualidade distintiva dos objetos de museu

$\checkmark$ A museologia como o estudo de uma relação especifica entre o homem e a realidade.

Diante da exaustiva, porém necessária apresentação cronológica dos encontros organizados pelo ICOFOM no período de 1977 até 1999, podemos destacar que em seus primeiros encontros publicados na MuWoP/DoTraM, a preocupação do Comitê concentrava-se na delimitação conceitual do campo da Museologia. Após o encerramento da MuWoP/DoTraM, a série de Estudos do ICOFOM (ISS) assume o papel de registrar e divulgar as discussões propostas pelo Comitê.

Ambas tratavam de questões fundamentais da Museologia e visavam instituir bases teóricas, de certo modo para conscientizar, pelo debate, o comitê e seus participantes, dos problemas que lhe seriam específicos, de tal forma que a Museologia fosse abordada como ciência (CERÁVOLO, 2004). É inegável a importância da contribuição de ambas as publicações, tanto para a Museologia quanto para os museus, no entanto, o seu alcance esbarra na sua 
distribuição, feita somente para um círculo restrito de destinatários (em geral os participantes e colaboradores do ICOFOM e de seus encontros), caminhando assim na contramão da proposta original de serem ambas "um fórum aberto de ideias" que atingiria um número grande de pessoas.

O que se vê nos anos seguintes desta trajetória de encontros, são diferentes abordagens para a criação de uma Teoria Museológica, para então, na década de 1990 após consolidada como ciência, a Museologia passasse a abordar problemáticas do âmbito mais prático e crítico de seu objeto de estudo ${ }^{17}$.

Vale ressaltar que, ainda vigente a ISS encontra-se na publicação de número $46^{18}$, sua distribuição antes restrita atualmente é feita de forma aberta e gratuita pela internet, onde é possível acessar todos os seus exemplares, desde a sua primeira publicação, adequando-se enfim a sua proposta inicial de amplo acesso.

Como podemos notar na capa representada na Figura 5, seus traços continuam os mesmos da inaugural de 1983 (Figura 4), em cor única e fonte simples, talvez um pouco mais chamativa pelo tamanho maior das letras. No entanto, o grande salto evolutivo está em seu conteúdo, pois avançada e superada as temáticas base de seu campo, a Museologia finalmente pode se dedicar ao aprofundamento de questões críticas e aprofundadas. O que dizer desta chamada intitulada "A Política e a Poética da Museologia”.

\footnotetext{
${ }^{17}$ Para consultar todas as temáticas discutidas pelo ICOFOM e publicadas na ISS, consultar: http://network.icom.museum/icofom/publications/icofom-study-series/

${ }^{18}$ Informação obtida em Janeiro de 2019.
} 
Figura 5: Capa da Série de Estudos do ICOFOM, n 46 de 2018

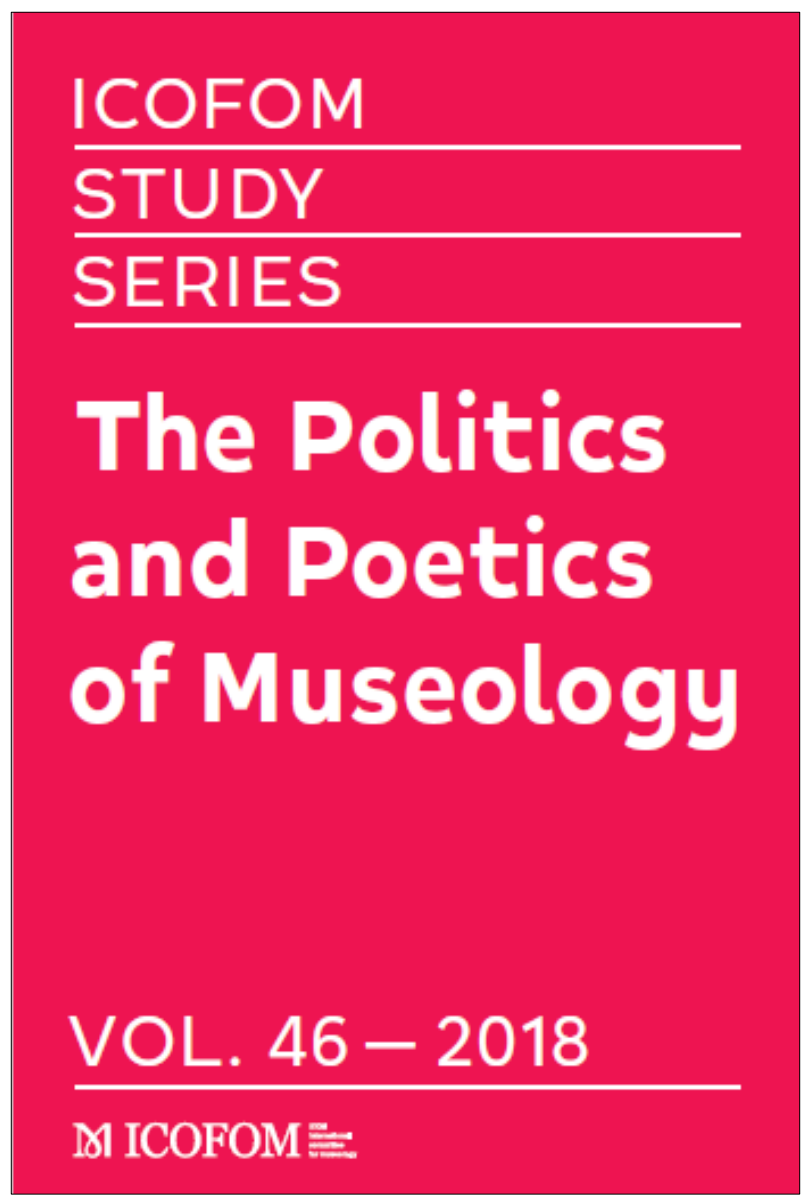

Fonte: network.icom.museum

Faremos agora um recorte sobre a trajetória de uma outra publicação de quase 100 anos, dedicada de maneira quase contínua a divulgação das práticas e consequente atualização dos museógrafos espalhados pelo mundo. A Revista apresentou sua primeira publicação em 1922 com o nome Mouseion, chancelada pela $\mathrm{OIM}^{19}$ - Organização Internacional de Museus (L’Office International des musées). Interrompida antes da Segunda Guerra e retomada em 1948 pela Organização da Nações Unidas para a Educação, a ciência e a Cultura (UNESCO), desta vez com o nome Museum, ela perdura até os dias de hoje (o periódico encontra-se no

\footnotetext{
${ }^{19}$ Cf. Cerávolo (2004, p. 333) Organismo ligado ao Instituto Internacional de Cooperação Intelectual (IICI) e esse à Organização Internacional do Trabalho (OIT), resultado de um pedido do governo francês à Liga das Nações, para que aceitasse acolher em Paris esse instituto. Tal organismo pretendia a cooperação intelectual entre especialistas, servindo de coordenadora internacional da conservação de obras de arte e monumentos históricos. Preocupava-se em organizar, criar normas legislativas e administrativas para gerir o patrimônio artístico e 'os múltiplos problemas da museografia técnica e administrativa'.
} 
volume $\left.70, \mathrm{n}^{\text {o }} 279-280\right)^{20}$, recebendo o nome atual, Museum International, a partir de 1993 (CERÁVOLO, 2004).

Em uma abordagem editorial renovada, desde os últimos cinco anos o periódico passou a ser gerenciado pelo ICOM, mesmo responsável pela ISS. Com muitas variações de forma e principalmente de conteúdo, a Museum International tornou-se ao longo dos anos um valioso fórum para o intercâmbio de informações científicas e técnicas sobre museus e patrimônio cultural. A pluralidade de temáticas aliada a interdisciplinaridade composta pela contribuição de áreas como a Antropologia, Arqueologia, História e História da Arte, Sociologia, Filosofia, Museologia e Economia, fizeram da revista um espaço único que permite que leitores e colaboradores participem da diversidade cultural através do patrimônio em todo o mundo, abordando questões relevantes para políticas culturais, ética e práticas em nível mundial. A diversidade característica em sua trajetória também está refletida em suas capas, variando muito em cores, fontes e imagens, ora a revista apresenta fotografias, ora montagens, tudo cuidadosamente pensado para comunicar o seu conteúdo.

Observamos na capa apresentada pela figura 6 que a temática museus em um mundo digital é apresentada de forma colorida com ao menos três cenas sobrepostas: no primeiro plano a visitante vivencia uma experiência digital utilizando um óculos de realidade virtual, estendendo a mão ela parece querer alcançar algo: o que poderia ser? uma obra de arte? um cenário? será que ela "está" no museu? A imagem parece incitar a nossa imaginação sobre as múltiplas possibilidades que o mundo digital pode oferecer ao museu. Logo atrás desta cena podemos ver uma mulher à frente de uma projeção, pelo seu gestual possivelmente uma mediadora, indicando que mesmo em se tratando de uma exposição com a temática digital e das liberdades que este tipo de exposição possibilita ao visitante, a presença de um mediador ainda é essencial para que a visita seja de fato enriquecedora. Mais distante ao fundo, visualizamos duas pessoas em frente a dois monitores, o que nos leva a pensar se estes aparelhos fariam parte da exposição ou trata-se de um ambiente do próprio museu aberto ao uso da comunidade, ampliando ainda mais a temática proposta nesta edição?

\footnotetext{
20 Informação obtida em Janeiro de 2019.
} 
Figura 6: Capa da Museum Internacional da UNESCO/ ICOM, vol. 70, nº 277-278 de 2018.

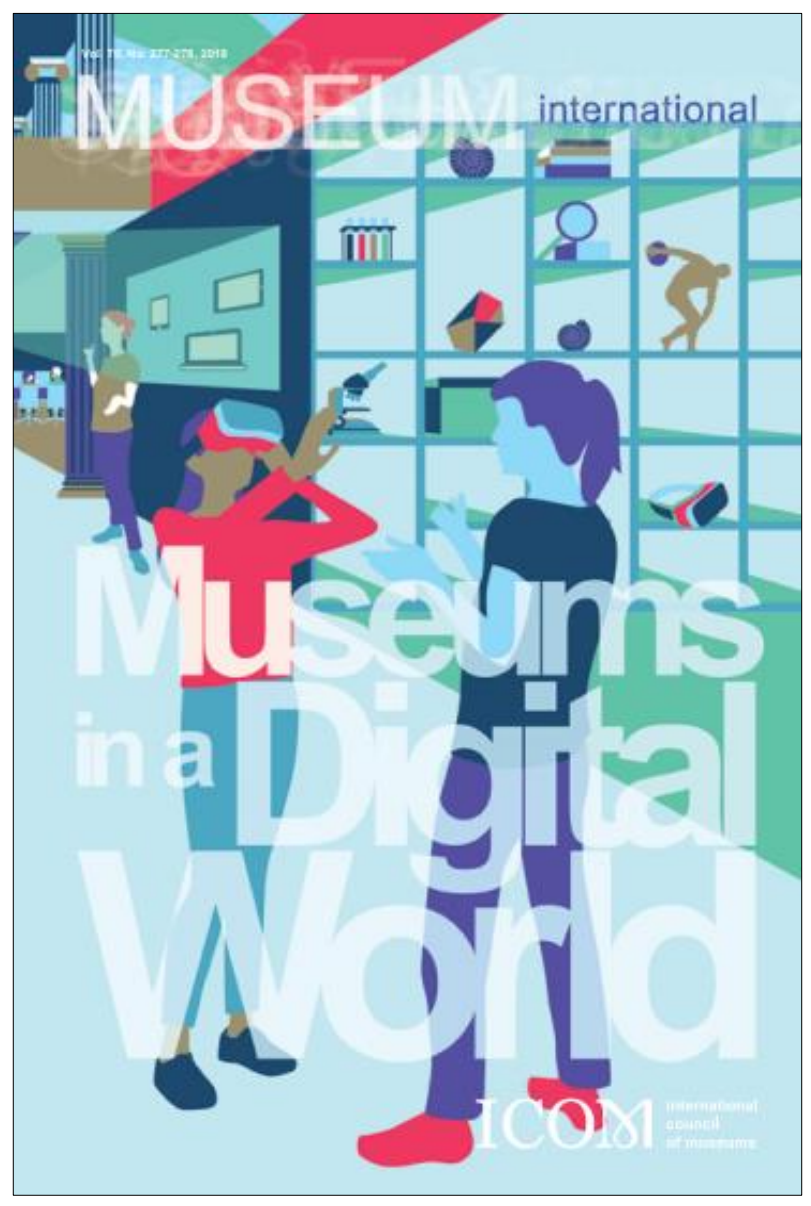

Fonte: onlinelibrary.wiley.com

Apesar dos objetos digitais em destaque, a capa também apresenta elementos tradicionais dos museus, como a estátua do escultor grego Míron, Discóbolo, presente na estante onde também podemos observar algumas carapaças de caracol, peças características dos museus de história natural. Os elementos do ambiente mesclam a arquitetura moderna e a clássica ao apresentar paredes lisas e neutras com colunas de Ordem Jônica que remetem a Grécia antiga, simbolizando que não somente seria possível como também necessário esta mistura entre tradicional e o novo. A proposta de diversidade do periódico fica evidente também na escolha de não caracterizar o rosto de seus personagens, remetendo a ideia de que este museu poderia ser de qualquer país. Como ultima observação desta figura, deixamos a seguinte reflexão: será que a escolha de usar somente personagens femininas é apenas uma coincidência ou uma homenagem para a numerosa e crescente presença das mulheres no universo museal?

Após apresentação destes três periódicos, relevantes para o desenvolvimento tanto da Museologia quanto do Museu, pontuamos que o que difere as publicações MuWop e ISS, da 
Museum International, além é claro da forma e do conteúdo, é principalmente seus destinatários. Desde o início o propósito da MuWop depois herdado pela ISS, era o de ser uma difusora da produção da ciência entre pares, enquanto que a Museum preocupava-se com a divulgação para o público geral. O elo que as une inegavelmente está no sujeito: o museu; nas palavras de Cerávolo (2004, p. 338) esta ligação permeia as temáticas "museus de, museus com, museus para, museus $e$." Cada qual a sua maneira contribuiu (no caso da extinta MuWop) e ainda contribui para o fortalecimento e aperfeiçoamento da teoria e das práticas museais, resultando na busca pelo constante aprimoramento dos serviços prestados pelo museu para a sociedade.

Esta abordagem de caráter histórico destaca ao seu fim que hoje amplamente reconhecida como uma área de pesquisa, ciência e disciplina acadêmica, a Museologia construiu suas bases teóricas ao longo do tempo e contribuiu amplamente para o desenvolvimento da prática museográfica. Valendo aqui uma distinção, o termo Museografia (mais antigo do que o termo Museologia), pode apresentar três acepções específicas: a arte da exposição e o conteúdo de um museu são duas delas, mas destacamos a concepção que se aplica a esta pesquisa, entendido como "a figura prática ou aplicada da Museologia” (DESVALLÉES e MAIRESSE, 2013, p.58).

O termo nesse ultimo sentido compreenderia "o conjunto de técnicas desenvolvidas para preencher as funções museais [...] particularmente aquilo que concerne à administração do museu, à salvaguarda (conservação preventiva, restauração e documentação) e à comunicação (exposição e educação)" (DESVALLÉES e MAIRESSE, 2013, p.58). Entende-se que apesar da distinção os limites e reciprocidades entre ambas, são imensuráveis. No entanto, ficamos com a mesma dúvida de Suely Moraes: "se existe um conhecimento desenvolvido a partir dos museus, e se esse conhecimento denominava-se Museologia, qual a trama a ser evidenciada entre ela e museus?" (CERÁVOLO, 2004, p. 331).

A partir da abordagem cronológica apresentada é possível afirmar que as ideias e os conceitos, em diversas conjunturas, se confundem com as trajetórias e, estas, com a prática dos museus. Assim, o Museu como fenômeno histórico e a Museologia como fenômeno epistemológico coexistem em uma via de mão dupla do conhecimento. 
Se a consolidação epistemológica dessa disciplina depende, em grande parte, de sua experimentação nos museus, estas instituições necessitam, em contrapartida, de orientação filosófica e conceitual, derivada dos paradigmas que alimentam a discussão em torno da Museologia. Neste sentido, o refinamento dos caminhos entre o sonho e a utopia reside na conciliação entre o desenvolvimento dos museus e as conquistas do pensamento museológico (BRUNO, 2006, p.8, grifo nosso).

Nesse sentido, a Museologia tem sido compreendida como "a disciplina aplicada que estuda o fenômeno museal, está vinculada aos sistemas de administração da memória e trata das representações do real”. Uma vez delineado o objeto de estudo dessa área de conhecimento, "as reflexões têm procurado desvelar o seu perfil ontológico (a essência de seu objeto de estudo), a sua epistemologia (o quadro referencial da disciplina) e os seus postulados éticos (função social)" (BRUNO, 2008, p.6).

No entanto, o desenvolvimento e a consolidação de um campo disciplinar depende, necessariamente, da "continuada revisão de seus fundamentos e premissas - e de uma perspectiva crítica sempre renovada sobre a sua produção". Esse ciclo possibilita identificar "os aportes constitutivos do campo e reconhecer as flutuações interpretativas que lhe enriquecem as estruturas" (SCHEINER, 2012, p.16) o que facilita as conexões entre o que está dito e as novas abordagens necessárias para os seus desafios.

Tendo como base, o que é Museologia e a sua abrangência, dentro deste mesmo panorama agora podemos abordar pontualmente o que proporcionou e incitou todos estes encontros e debates no universo museal, resultando na efetiva renovação de todos os museus do século XXI: A Nova Museologia.

\subsubsection{Nova Museologia}

Como salientamos no item 3.1, durante muito tempo a Museologia foi entendida e reduzida a 'ciência dos museus', quando na verdade conforme exposto anteriormente, esta nova ciência passou por inúmeros debates que, em um primeiro momento, buscavam sim definir o seu objeto de estudo, mas que, em um segundo momento, discutiu exaustivamente em diversos encontros a necessidade de expandir o seu objeto de estudo. Tendo fundamentado a sua teoria 
e envolta em seus próprios paradigmas, surge então em meio aos encontros apresentados no item 3.1, algo que transformaria completamente a Museologia e principalmente os museus: A Nova Museologia.

Diante de tantas transversalidades que o conhecimento perpassa, Cury (2014, p. 63) coloca a importância e as contribuições da Nova Museologia, mas ressalta que na realidade não se trata de "uma outra em contraste com a antiga mas sim um modelo metodológico de interação entre o patrimônio cultural e a sociedade". A autora também aponta que:

\footnotetext{
Nesse modelo, o público é agente das ações de preservação e comunicação patrimonial e o processo é tomado como educacional, por ser transformador. Enquanto modelo inovador, a Nova Museologia trouxe várias contribuições e, sobretudo, agregou valores ao embate sobre a "crise dos museus" na medida que se propõe ao enfrentamento entre os bens culturais e o público em todas as suas possibilidades e potencialidades (CURY, 2014, p 63).
}

Vejamos, muito embora a Nova Museologia não esteja em contraste com a antiga, ela representa uma mudança radical na maneira como a museologia e os museus entendem e dialogam com o público. Além disso, ela foi responsável por abrir os olhos de ambos para áreas até então tratadas como não prioritárias, "de fato, a partir da virada da "Nova Museologia" no decorrer da década de 1970, a disciplina se interessa essencialmente pelas dimensões sociais, filosóficas e políticas, até então negligenciadas” (POULOT, 2013, p.129). Concomitantemente, é instaurado também debates sobre a natureza da instituição, sobre o caráter e significado das suas coleções, das suas modalidades de representação cultural, da sua identidade institucional, até da sua missão e do seu lugar na sociedade (DUARTE, 2013).

Importa salientar que o conjunto de inovações museológicas supramencionadas, as quais podemos chamar de uma verdadeira "renovação museológica", alcança propagação na década de 1970, mas isso não significa afirmar que, tais mudanças encontraram adesão total das instituições museais, muito menos apoio e diálogo por parte de todos os profissionais de museus - os museógrafos; que confrontados, viram-se as voltas com um conjunto bem maior de acadêmicos, estudiosos e colaboradores em geral interessados em colocar em prática as discussões promovidas nos encontros do ICOFOM.

Para que tais mudanças fossem possíveis, ainda que não em sua totalidade, toda uma conjuntura política, econômica, social foi transpassada em âmbito local e mundial (estamos 
falando principalmente dos anos 1970 e 1980), com inúmeras problemáticas que permitiram e incentivaram esta transformação, das quais a seguir destacaremos alguns momentos e seus documentos resultantes especialmente decisivos que ocorreram dentro do universo museológico:

\section{- 1972 - Santiago, Chile - realização da Mesa Redonda de Santiago do Chile}

Evento organizado pelo ICOM e pela UNESCO, com discussões que abordavam um museu enquanto instrumento de mudança social, aberto à comunidade e responsável por ela, estamos falando finalmente do momento em que de fato o Museu passou de Museu público para Museu a serviço do público, indagação feita no final do Capítulo 2.

A Mesa Redonda de Santiago do Chile foi a grande precursora no debate sobre a função social do Museu, temática que será aprofundada logo mais. A partir deste momento a instituição não será mais tratada como um local responsável apenas pelo abrigo e conservação de objetos, a estas funções serão agregadas inúmeras outras das quais algumas mencionamos anteriormente e pela primeira vez entende-se que a junção destas atribuições compõe uma única função: a função social do Museu.

A relevância e a profundidade de cada palavra contida neste documento vão além de sua época e transpõe o universo da museologia, tornando-o leitura obrigatória para uma reflexão sobre a nossa sociedade.

Documento Referencial: Declaração de Santiago ${ }^{21}$

\section{- 1984 - Declarações de Quebec e de Oaxaca}

A declaração de Quebec, documento que tem como subtítulo "Princípios de base de uma Nova Museologia 1984" reconheceu na Nova Museologia um movimento museológico, formalizando no ano seguinte o MINOM - Movimento Internacional por uma Nova Museologia, sediado em Lisboa, como uma organização filiada ao ICOM.

\footnotetext{
${ }^{21}$ Disponível em: http://www.minom-portugal.org/docs-santiago1972.pdf Para consulta ao documento original e algumas reflexões, acessar: http://www.ibermuseus.org/wpcontent/uploads/2014/09/Publicacion_Mesa_Redonda_VOL_I.pdf
} 
Trata-se de um documento internacional que defende que o saber isolado da museologia tradicional estava em contraponto com a necessidade de se trabalhar com reflexões mais profundas, amplas e críticas do universo museal.

Sendo assim, a interdisciplinaridade proposta pela Nova Museologia introduziu discussões em torno de conceitos como: ação comunitária, construção para o futuro, preservação como ação comunitária, responsabilidade coletiva, museu integrado com a comunidade, museu e educação popular, educação permanente, educação libertadora, museu e meio ambiente (CÂNDIDO 2002). Vale salientar que as diretrizes propostas pela Declaração de Quebec, em momento algum nega ou diminui todo esforço feito pela Museologia. "Suas atribuições e funções tradicionais de identificação, de conservação e de educação", tão somente permanecem importantes, como também são potencializadas, ampliando o seu lastro e integrando a população às suas ações (DECLARAÇÃO DE QUEBEC, 1984, p.1).

No mesmo ano de 1984, a declaração de Oaxaca propõe que ambas as museologias, a Tradicional e a Nova, assumam que a relação Homem - Objeto - Cenário, não se sustenta mais sem o entendimento da relação Homem/Sociedade - Objeto/Patrimônio Cenário/Território (figura 7).

Figura 7: novo lugar metodológico da museologia

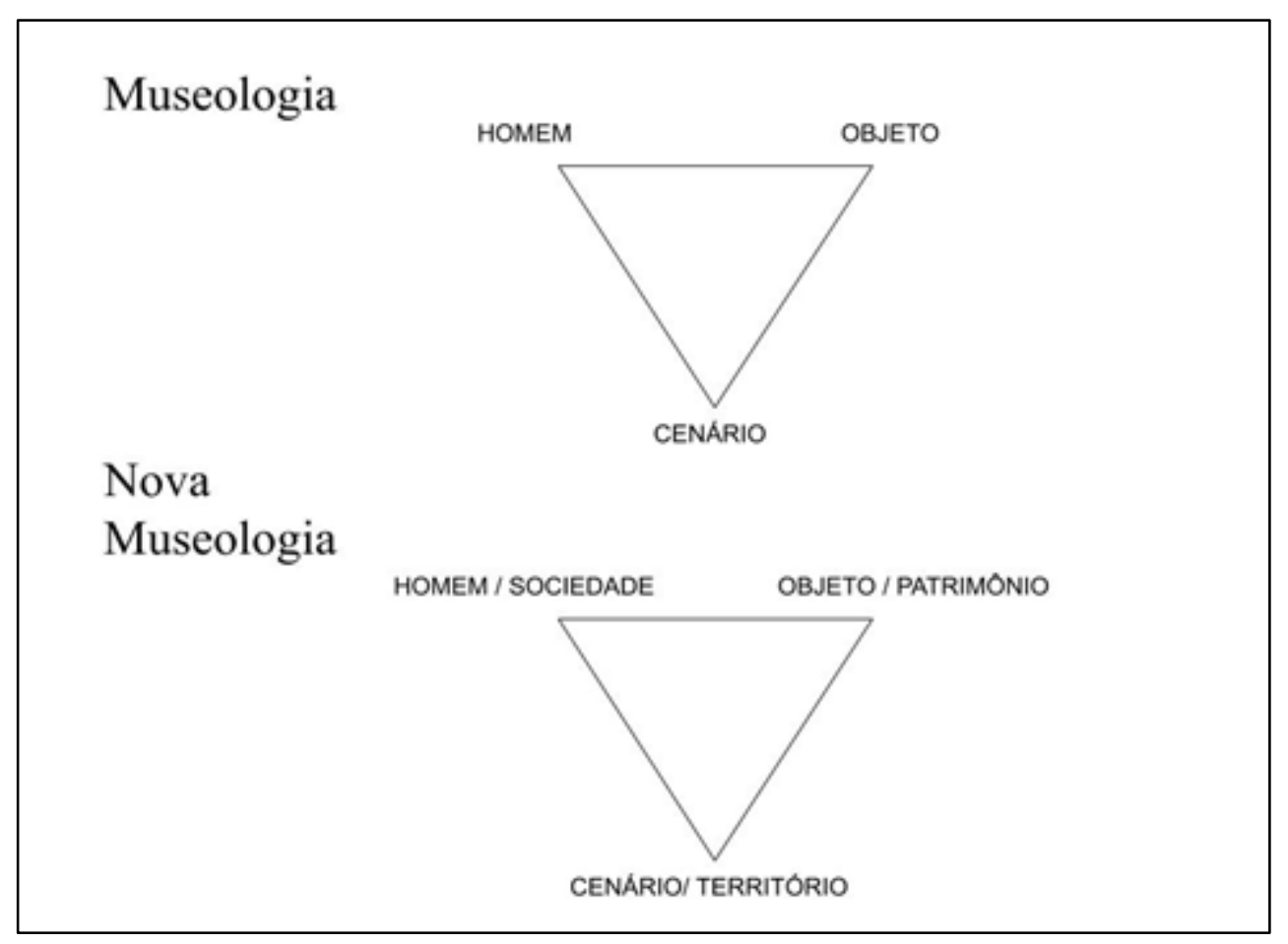

Fonte: Cury, 2014. 
Não se trata de uma mudança ou uma troca do objeto de estudo da museologia, mas sim uma ampliação, neste modelo proposto pela Nova Museologia o lugar metodológico é expandido, “o fato museal permanece, mas a forma de analisá-lo mudou. Deslocou-se definitivamente o foco de análise do museu para o cotidiano das pessoas. E a museologia e o museu participam sendo eles mesmos mediadores dos processos de significação do patrimônio" (CURY, 2014, p. 67).

Documentos Referenciais: Declaração de Quebec ${ }^{22}$ e Declaração de Oaxaca.

\section{- 1992 - Declaração de Caracas}

A declaração de Caracas analisou especificamente a situação dos museus da América Latina. Exatamente vinte anos após a Mesa Redonda de Santiago, esta Declaração carregava o propósito de atualizar conceitos e renovar compromissos. Ela também propôs reformulações das políticas de formação e conservação de acervo, de pesquisa, de educação e comunicação, mudanças hoje essenciais para o museu contemporâneo.

Documento Referencial: Declaração de Caracas ${ }^{23}$

Muito mais do que a adição de um adjetivo à palavra Museologia, a Nova Museologia remete para um conjunto abrangente de problemáticas interdisciplinares, que muitas vezes necessitam de posturas particulares em cada caso, demandando o entendimento de que o termo em si perde relevância quando tratado de forma singular, devendo ser adotado (em um mundo ideal) no plural: Museologia(s).

Dentre duas dimensões museológicas: a sonhada e a real, fato é que as mudanças proporcionadas pela Nova Museologia foram essenciais para a renovação da instituição museológica no final do século XX, como ainda serão na renovação do museu do século XXI. Para além de recomendações e propostas, estes momentos e documentos, assim como todas as pessoas envolvidas nestes processos, representam marcos referenciais para a Museologia e para o Museu, que antes passivo, ordena-se ativo. Antes deles, pensar em um museu interativo, presente e dinâmico era como imaginar um museu utópico, algo impossível de se concretizar, mas juntos eles foram capazes de estabelecer uma base sólida para que ambos se

\footnotetext{
${ }^{22}$ Disponível em: http://www.minom-portugal.org/docs-quebec1974.pdf

${ }^{23}$ Disponível em: http://www.minom-portugal.org/docs-caracas1992.pdf
} 
complementassem unindo prática e teórica em prol da sociedade, o que para Bruno (2008, p. 5) representa "uma outra área do conhecimento, apontando para os estudos sociomuseológicos."

Após tantos acontecimentos, fóruns, declarações e publicações, fica evidente que muito mais do que um termo ou um movimento transitório, a Nova Museologia de fato abre o museu para a pluralização de vozes, e é por meio dela, que o museu adquire seu mais valioso presente: a autocrítica sobre a sua real função social.

\subsubsection{A função social do museu}

Muito além de conceitos, a verdadeira contribuição da Nova Museologia foi a de pensar um museu de forma diferente, "graças a ela é que o museu deixou de ser, pelo menos maioritariamente, o lúgubre depósito de objetos que já foi” (DUARTE, 2013, p. 116). Vale relembrar que a mesa-redonda da UNESCO de 1972, em Santiago do Chile, enfatizou, em particular, a dimensão social dos museus, abrindo uma perspectiva de compromisso por parte da profissão que nunca mais foi desmentida (POULOT, 2013). Refletir sobre os museus e suas diferentes funções significa pensar na responsabilidade social que esta instituição possui, não por acaso conforme apresentado anteriormente, a noção de museu veio sendo ao longo dos anos profundamente debatida e ampliada, com ênfase nas últimas décadas na discussão da sua função social. E se hoje discutimos a função social museal é porque a Nova Museologia proporcionou este debate.

Antes de prosseguirmos, gostaríamos de clarear o que foi a construção e definição do conceito de função social dos museus.

Ao longo das décadas de 1960 e 1970, durante a efervescência do movimento pela Nova Museologia, as críticas aos museus se acentuaram em meio a crescente insatisfação política e de movimentos pela democratização da cultura, realidade que iniciaria na Europa, mas logo atingia diferentes países do mundo. E os caminhos para a democratização da Cultura perpassam pelos caminhos de democratização dos museus. Os adventos no início deste paradigma culminaram no movimento da Nova Museologia, que por sua vez clamava, por assim dizer, por um “Novo Museu”. Os museus então iniciaram um processo de reformulação 
de suas estruturas, procurando compatibilizar suas atividades com as novas demandas da sociedade, para tanto contaram com outra transformação: a multiplicação das áreas de conhecimento dos profissionais e acadêmicos atuantes no universo museal, até então extremamente restrita a relação tempestuosa com a Antropologia. Neste contexto o ICOM assumiu o papel de incentivador das novas exigências de utilidade social dos museus e do patrimônio, por meio de suas conferências gerais e da publicação de múltiplos documentos resultantes de seus diferentes comitês. Alguns destes apresentados e analisados nos itens $3.1 \mathrm{e}$ 3.1.1 desta dissertação.

Relembrando a definição supracitada ${ }^{24}$ do ICOM (2009), o Museu possui declaradamente e por que não afirmar, oficialmente, algumas funções perante a sociedade: adquirir, conservar, pesquisar, comunicar e expor os testemunhos materiais e imateriais do homem e de seu meio. Todavia as funções indexadas em sua definição, que de certa forma atualmente funcionam como uma condição para a existência de um museu, não foram eleitas a esmo e apesar de serem apresentadas no paradigma atual, elas foram lentamente delineadas no decorrer da longa trajetória museológica, permeando todos os paradigmas do conhecimento; GrecoRomano, Judaico-Cristão e Ciência Racional, cada qual a seu tempo fortaleceu, aprimorou, ofereceu e agregou novas funções ao Museu.

Afinal, o que seria a função social do Museu?

Não se trata de uma única função, ao contrário, trata-se de um conceito medrante, ou seja, que cresce indefinidamente, o que pela natureza da instituição Museu de acompanhar o desenvolvimento da sociedade, nos aponta que este conceito jamais será delimitado.

Investigar, questionar, denunciar, inovar, preservar, colecionar, coletar, estudar, interpretar, pesquisar, educar, transmitir, debater, dialogar, conscientizar, valorizar, incentivar, entreter, democratizar [...] a união destas e de muitas outras funções inerentes ao Museu e ao imaginário das pessoas sobre o que é um museu, compõe a sua função social, função esta que por meio do diálogo proporcionado pelo lazer cultural (temática que abordaremos no decorrer desta dissertação) tornou-se o motivo da proliferação da instituição no paradigma atual. Assim Bruno (2006) lembra que "os museus têm assumido o desafio de trabalhar a partir dos mais

\footnotetext{
${ }^{24}$ Para relembrar a definição completa, consultar a página 24 desta dissertação.
} 
diferentes acervos, para distintos segmentos das sociedades, em todas as regiões do mundo, procurando explicitar as características da nossa condição humana” (BRUNO, 2006, p.9). Portanto, para cumprir com a sua recente reformulada complexa função social, coube ao Museu, para manter-se vivo e ativo, criar diferentes estratégias para aproximar o público do seu acervo, que neste paradigma tornou-se indiscutivelmente patrimônio de todos. Enfim, $\underline{o}$ museu reajusta a sua função.

Com o desejo de atender as diferentes funções que compõem a sua função social, este paradigma testemunhou o fortalecimento dos museus de arte, história e arqueologia [...], mas também impulsionou o surgimento de outras modalidades de museu como os de ciências, etnográficos, comunitários/ecomuseus, museus casa, virtual, museus cidade, museus temáticos etc. Essa diversidade hoje alcançada surge como uma resposta dos museus para a sociedade, posicionando-se a serviço do desenvolvimento da mesma ele parece finalmente compreender que para melhor suprir uma variada gama de necessidades e desejos, o modelo tradicional de museu já não atenderia completamente a estes anseios. Zavala (2001) aponta que as transformações ocorridas nas ciências sociais nos últimos 40 anos, provocadas essencialmente pela transdisciplinaridade afetaram diretamente os museus, criando o que o autor coloca como dois paradigmas (museais): o tradicional e o emergente.

Tais mudanças representam o que chamaremos de transgressão paradigmática, ou seja, o ápice da mudança dentro de um paradigma, o momento em que algo definitivamente deixa de existir ou coexiste de maneira ínfima com o novo - o que pode ocorrer em áreas específicas da nossa sociedade. Isso significa que dentro do paradigma atual pode haver transgressões paradigmáticas em áreas distintas, de forma isolada e até simultânea, o que não implicaria necessariamente em uma transição do Paradigma do conhecimento.

No entanto, se estas transgressões ocasionarem uma cadeia de eventos significativa em setores pilares da sociedade, podemos estar sim diante de sinais que nos indicam o que Souza (2017, p. 14) denominou como um novo "horizonte histórico", ou seja, um novo paradigma do conhecimento.

Neste caso e nesse momento, estamos falando de uma transgressão dentro do universo museal. Cury (2014b) organizou as ideias de Zavala (2013, p. 19) condensando-as na figura 7 que exibe as principais características desta transgressão. 
Figura 8: comparativo entre paradigmas tradicional e emergente.

\begin{tabular}{|c|c|}
\hline \multicolumn{2}{|c|}{ Aproximação de paradigmas para os museus } \\
\hline Tradicional & Emergente \\
\hline Visita como obtenção de conhecimento & $\begin{array}{l}\text { Visita como possibilidades múltiplas e } \\
\text { únicas }\end{array}$ \\
\hline Valorização do conteúdo da exposição & $\begin{array}{l}\text { Valorização do diálogo entre cotidiano e } \\
\text { experiência de visita ao museu }\end{array}$ \\
\hline Naturalização do significado & $\begin{array}{l}\text { Contextualização social de produção do } \\
\text { significado }\end{array}$ \\
\hline Objetividade expográfica & Subjetividade e intersubjetividade \\
\hline $\begin{array}{l}\text { Experiência como representação clara e } \\
\text { convincente do mundo }\end{array}$ & Experiência museal ritualística e lúdica \\
\hline Ênfase na visão e no pensamento & $\begin{array}{l}\text { Espaço para a afetividade, emoção e } \\
\text { multissensorialidade }\end{array}$ \\
\hline $\begin{array}{l}\text { A autoridade recai sobre os especialistas } \\
\text { do museu }\end{array}$ & O visitante é ativo e autônomo \\
\hline O museu é uma janela para realidades & $\begin{array}{l}\text { O museu é uma oportunidade para a } \\
\text { construção simbólica }\end{array}$ \\
\hline Experiência e circuito museal coincidem & $\begin{array}{l}\text { Experiência museal extrapola os muros } \\
\text { do museu }\end{array}$ \\
\hline
\end{tabular}

Fonte: Cury, 2014b.

Se, por um lado, o museu tradicional preocupa-se com a entrega do conhecimento por meio do conteúdo expográfico, naturalizando os significados em uma experiência baseada na visão convincente de mundo proporcionada pelos especialistas do museu, o museu emergente por sua vez volta-se para o diálogo entre o que o público carrega de conhecimento e o que o museu propõe como experiência de visitação, proporcionando múltiplos objetivos para cada visita, os significados são contextualizados quanto a sua produção e a experiência museal é subjetiva, intersubjetiva e simbólica provocando emoções por meio da multissensorialidade, extrapolando o espaço do museu.

O museu emergente caracterizado por Zavala apresenta nuances entre utopia e realidade quanto a sua práxis. Concordamos com Cury (2014b) ao observar que nem todos os elementos do museu emergente foram incorporados, a autonomia do visitante e a extrapolação da experiência para o seu cotidiano ainda são elementos inexistentes na maioria dos museus. Por sua vez os elementos característicos do museu tradicional encontram cada vez menos o 
seu lugar na práxis confrontada pela sociedade, evidenciando o conflito existente atualmente no universo museal. Embate este causado pela necessidade de alcance de suas novas funções e já previsto durante a Mesa Redonda de Santiago que dizia que:

[...] a transformação das atividades dos museus exige a mudança progressiva da mentalidade dos conservadores e dos responsáveis pelos museus assim como das estruturas das quais eles dependem; que, de outro lado, o museu integral necessitará, a título permanente ou provisório, da ajuda de especialistas de diferentes disciplinas e de especialistas de ciências sociais (DECLARAÇÃO DE SANTIAGO, 1972, p. 3).

Nesta ocasião e ainda hoje a preocupação centra-se na seguinte questão: será que a instituição existente seria capaz de cumprir as suas novas funções e finalidades?

A prioridade atribuída à participação e desenvolvimento integrado das populações "exige da parte dos profissionais a adoção de um renovado aparato conceptual que os auxilie a concretizar a mudança de um museu centrado nas suas coleções para outro, centrado nas suas funções sociais" (DUARTE, 2013, p. 110). Assumir sua responsabilidade social é uma tarefa tão difícil quanto necessária. Para cumprir com a sua função social a instituição vem dia após dia se transformando para se aproximar e dialogar cada vez mais com a sociedade.

Para Semedo (2013, p. 53), "atualmente os museus aspiram a serem lugares de 'emaravilhamento', de encontro, e de reflexão, de criatividade e de aprendizagem deixando, assim, de se desenharem como meros repositórios de objetos”. Este lugar de "emaravilhamento" ao qual Semedo se refere nada mais é do que um museu que desempenhe com o maior êxito que lhe é possível a sua complexa função social, o que, para Bruno (2006), vem ocorrendo há algum tempo:

Nas últimas décadas, os museus têm desempenhado um papel relevante e especifico no campo da democratização da cultura, rompendo as barreiras dos seus espaços tradicionais, procurando novos públicos e criando exposições que incorporam linguagens mistas. Estas instituições experimentam novos modelos de gestão, aproximando-se em programas de redes e sistemas, sem, entretanto, perder a noção de seu campo essencial de atuação (BRUNO, 2006, p. 17).

Se o final do paradigma Ciência Racional e o começo deste paradigma, nos presenteou com a "era dos museus" (surgimento de um grande número de museus). A recente conjuntura, 
repleta das experimentações de novos modelos, apontada por Bruno (2006), nos brinda com a diversidade de tipologias de museus e dentro desta diversidade ainda apresentam-se algumas especificações.

Cada museu responde a algum aspecto do saber humano. Concentra-se, especializa-se e torna-se, antagonicamente, mais amplo. Os museus de arte, por exemplo, são apresentados de formas distintas: alguns se destinam a arte de um século, outros abordam um tipo especifico de arte (como arte moderna ou contemporânea), há ainda os que se dedicam a apenas um artista, mas sem dúvida, todos, cada qual com a sua missão, ainda que de formas diferentes, se dedicam à arte. A arte que no paradigma anterior estava concentrada em poucos e grandiosos museus (essencialmente europeus) centrada em artistas renomados (também essencialmente europeus) e restrita a um público (mais uma vez, essencialmente europeus), encontrou caminhos para fluir além mar, cruzando a linha do equador e finalmente como supracitado por Bruno (2006, p.17) "romper as barreiras dos seus espaços tradicionais, procurando novos públicos e criando exposições que incorporam linguagens mistas”.

A busca pelo alcance da função social ampliou o horizonte da instituição, coexistindo em certa harmonia novas representações de museus: pequenos e grandes, locais e globais, estéticos e pedagógicos, interativos e preservadores, turísticos e comunitários, inovadores e conservadores; e em novos artistas: renomados e desconhecidos, homens e mulheres, falecidos e vivos, com técnicas antigas e novas técnicas; e em novos públicos: turistas e comunidade, novos e velhos, frequentadores e não frequentadores, pobres e ricos, interessados e desinteressados. Por meio deste exemplo podemos vislumbrar que o museu pluralizou-se em forma, conteúdo, finalidade e principalmente em público e na maneira de interagir com ele, atendendo (ainda que não em sua totalidade) as diferentes necessidades e desejos da sociedade, a máxima da função social museológica.

Diante do exposto, apresentamos o Quadro 4, só que desta vez pontuamos que as respostas consolidadas neste $4^{\circ}$ Paradigma, referente aos questionamentos condutores da análise associativa entre os paradigmas do conhecimento e a trajetória museal apresentam-se como provisórias, afinal, em sua essência, o conhecimento deste paradigma é compreendido como provisório. Ademais, estamos vivenciando-o, o que nos permite o aprimoramento futuro dessas respostas. 
Quadro 4: Principais características $4^{\circ}$ Paradigma: Atual - Século XX.

O que é conhecimento? Passível de falhas, provisório e em busca da interdisciplinaridade

O que é museu? Uma instituição plural em forma, conteúdo, finalidade e público

A que se destina? A atender as necessidades e desejos da sociedade de acordo com a sua função social

A quem se destina? Quem o frequenta?

Toda a sociedade

Fonte: Elaboração própria, 2018.

De forma alguma estamos afirmando que todo e qualquer museu trabalha em busca de sua função social (ainda que se trate de uma obrigação institucionalizada), estamos, sim, exaltando exatamente as iniciativas. Sabemos que muitos não a alcançam por falta de meios (funcionários, funcionários especializados, material, verba, interesse do poder público, desinteresse por parte da sociedade etc.) outros sequer a almejam. $\mathrm{O}$ tradicional, o elitizado, coexiste enquanto interesse e isto não é um artifício e sim tal qual aponta Cury (2014b, p. 63) é "uma forma de funcionamento da hegemonia que, em uma de suas manifestações, é segregadora". Não podemos esquecer que apesar da afirmação de que o Museu se destina a toda a sociedade e que toda ela o frequenta, ele está inserido em uma sociedade desigual e segregadora, o que coloca um justo contraponto a esta afirmação, todavia, não podemos negála ao passo que tais proibições não provêm diretamente da Instituição como outrora nos paradigmas antecessores.

Não podemos também definir o museu deste paradigma como $100 \%$ tradicional ou $100 \%$ emergente, a verdade é que cada um ainda encontra o seu espaço, bem como o seu público. Estamos vivenciando a transgressão paradigmática museológica, onde o museu emergente ganha território na medida em que quase proporcionalmente o tradicional perde, mas não sem alguma resistência.

Se os museus deste $4^{\circ}$ Paradigma não pertencem totalmente do modelo tradicional, nem completamente do modelo emergente, como ele pode ser caracterizado? Para responder a esta questão recorremos novamente a Cury (2014b), que inspirada por García-Canclini (1999); Zavala (2003); Martín-Barbero (1997) e na práxis, elaborou um terceiro modelo: o museu em 
transição; e a partir das características de cada um: tradicional, em transição e emergente, criou um quadro comparativo entre os três (figura 8).

Figura 9: Comparativo entre museu tradicional, em transição e emergente.

\begin{tabular}{|c|c|c|}
\hline Museu Tradicional & Museu em Transição & Museu Emergente \\
\hline Museu nação & Museu diversidade e diferença & Museu desglobalizante \\
\hline $\begin{array}{l}\text { Memória e identidade no } \\
\text { singular }\end{array}$ & Memória e identidade no plural & $\begin{array}{l}\text { Memórias e identidades } \\
\text { circunstanciais }\end{array}$ \\
\hline Patrimônio como ideia fechada & $\begin{array}{l}\text { Patrimônio como ideia aberta e } \\
\text { em mudança, muitas } \\
\text { possibilidades } \\
\text { (re)interpretações }\end{array}$ & $\begin{array}{l}\text { Patrimônio e exercício criativo e } \\
\text { de poder }\end{array}$ \\
\hline $\begin{array}{l}\text { Patrimônio como estratégia de } \\
\text { educação }\end{array}$ & $\begin{array}{l}\text { Patrimônio como ponte de } \\
\text { aproximação entre sociedades e } \\
\text { culturas distintas, tempos e } \\
\text { espaços }\end{array}$ & $\begin{array}{l}\text { Heterogeneidade, } \\
\text { multiplicidade, pluralidade, } \\
\text { fragmentação }\end{array}$ \\
\hline Agenda limitada & Agenda múltipla & Agenda aberta \\
\hline \multirow[t]{6}{*}{ Excludente } & Inclusivo & Ampla participação \\
\hline & Improdutivo & Insatisfeito \\
\hline & $\begin{array}{l}\text { Vive um dilema com a lógica do } \\
\text { mercado }\end{array}$ & Enfrenta o mercado \\
\hline & Tenso & Intenso \\
\hline & Incerto & Plástico \\
\hline & Crítico e contestador & Simbólico e político \\
\hline Discurso fechado & $\begin{array}{l}\text { Discurso = sinergia entre } \\
\text { narrativas múltiplas } \\
\text { multivocalizadas }\end{array}$ & Discurso em construção \\
\hline Unificador & Diversidade & $\begin{array}{l}\text { Fragmentado, múltiplo, plural e } \\
\text { diverso }\end{array}$ \\
\hline \multirow[t]{3}{*}{ Terceira pessoa gramatical } & $\begin{array}{l}\text { Terceira e primeira pessoa } \\
\text { gramatical }\end{array}$ & Primeira pessoa gramatical \\
\hline & Diálogo entre o local e o global & Diálogo entre o local e o global \\
\hline & Desterritorialização & Reterritorialização \\
\hline Educação como instrução & $\begin{array}{l}\text { Educação como ensino- } \\
\text { aprendizagem }\end{array}$ & Educação como experiência \\
\hline Educa / Instrui & Educa / Se educa & $\begin{array}{l}\text { Cria situações performáticas, } \\
\text { ritualísticas e lúdicas }\end{array}$ \\
\hline $\begin{array}{l}\text { Comunicação } \\
\text { transmissão }\end{array}$ & $\begin{array}{l}\text { Comunicação como capacidade } \\
\text { de diálogo com o público }\end{array}$ & Comunicação \\
\hline Sentido único & Polissemia & Polissemia \\
\hline Significado fechado & Significação aberta & Significação circunstancial \\
\hline $\begin{array}{l}\text { Acesso como possibilidade de } \\
\text { visitação }\end{array}$ & $\begin{array}{l}\text { Acesso como direito à } \\
\text { informação e ao entendimento }\end{array}$ & $\begin{array}{l}\text { Acesso como reconhecimento } \\
\text { do diferente }\end{array}$ \\
\hline $\begin{array}{l}\text { Curador = pesquisador de } \\
\text { coleção }\end{array}$ & Curador = profissionais diversos & $\begin{array}{l}\text { Curador }=\text { profissionais } \mathrm{e} \\
\text { públicos }\end{array}$ \\
\hline \multirow[t]{2}{*}{ O público precisa do museu } & O museu precisa do público & O museu é o público \\
\hline & Democrático & Solidário \\
\hline
\end{tabular}

Fonte: Cury, 2014b (grifo nosso).

O museu em transição apontado por Cury como o Museu do paradigma atual é fruto das reivindicações por sua função social. Como podemos analisar na figura 8, não se trata de uma mistura entre o tradicional e o emergente, o museu em transição, apesar do nome, tem uma 
identidade própria. A pluralidade da identidade e da memória se distancia da abordagem singular do tradicional, entretanto, não está sequer próxima da identidade e memória circunstancial almejada pelo museu emergente. Por sua vez o museu em transição inclusivo, é uma resposta ao tradicional que exclui, no entanto, esta inclusão só é necessária porque ele mesmo (o em transição) é por vezes excludente, "por isso ele é contraditório, pois nega o museu tradicional sem deixar de sê-lo totalmente" e ao ambicionar a ampla participação, o museu emergente "supera as duas questões" (Cury, 2014b, p. 64).

A sinergia entre narrativas múltiplas e multivocalizadas, pressupõe que há espaço para todas as formas de saberes, sem distinção ou discriminação entre eles. Mas será que isso acontece na práxis? Infelizmente, não. Nas palavras de Cury (2014 b) "sabemos, há muitas formas de saberes e, as reconhecendo ou não, o museu ainda não sabe como inseri-las na sua práxis" (Cury, 2014b, p. 64). Todavia, afirmar que não sabe como inseri-las, não significa dizer que o Museu de hoje mantenha o discurso fechado de outrora, significa que a essência do museu em transição é a experimentação, é o aprendizado, sendo assim, suas ações são questionáveis, e que, portanto, devem ser questionadas.

Talvez o maior distanciamento entre os três modelos, seja quanto ao acesso. Deveras, conforme apresentamos anteriormente, foram necessários três paradigmas para superar muitas restrições (ainda que em seu tempo histórico, não fossem necessariamente consideradas restrições), explícitas e implícitas, de dentro e de fora ao livre acesso de todos ao museu. $\mathrm{O}$ acesso como apenas uma possibilidade de visitação, apesar de recente na trajetória dos museus parece ter ficado em um passado longínquo e fora superado. Já o acesso como direito à informação e o entendimento, consolidou-se rapidamente. No entanto, o acesso como direito, está distante do acesso como reconhecimento. $\mathrm{O}$ direito apresenta fragilidades em nossa sociedade e pode a qualquer momento ser questionado e até mesmo destituído, o reconhecimento por sua vez empodera e o empoderamento fortalece e perpetua, o que o torna ao mesmo tempo um imenso desafio e uma prerrogativa para o futuro dos museus.

É evidente que, nem todas as diferenças entre os três modelos são tão delimitadas, para Cury (2014, p. 66) "nem tudo é passado e nem tudo é futuro, nem tudo é negação e nem tudo é afirmação". E essa é a ideia da transição, ela é necessária para entender porque fazemos experimentações, o quê negamos, o quê propomos e o quê de fato construímos. 
Oportunamente retomamos neste momento as principais características do paradigma atual iniciado no século XX e elaboramos o Quadro 5, fazendo uma relação entre as características do paradigma vigente apresentadas anteriormente no Quadro 4, e os elementos do museu em transição.

Quadro 5: Relação entre as características do $4^{\circ}$ Paradigma e os elementos do Museu em transição

$4^{\circ}$ Paradigma. Atual - Século XX...

\begin{tabular}{|c|c|}
\hline $\begin{array}{l}\text { Conhecimento passível de falhas, provisório e em busca } \\
\text { da interdisciplinaridade }\end{array}$ & $\begin{array}{l}\text { Patrimônio como ideia aberta e em mudança, muitas possibilidades de } \\
\text { (re)interpretações } \\
\text { Inclusivo; Improdutivo; Vive um dilema com a lógica do mercado; Tenso; } \\
\text { Incerto; Crítico e contestador }\end{array}$ \\
\hline \multirow{5}{*}{$\begin{array}{l}\text { Museu como uma instituição plural em forma, conteúdo, } \\
\text { finalidade e público }\end{array}$} & Agenda múltipla \\
\hline & Diversidade \\
\hline & Terceira e primeira pessoa gramatical \\
\hline & Diálogo entre o local e o global \\
\hline & Desterritorialização \\
\hline \multirow{4}{*}{$\begin{array}{l}\text { O museu se destina a atender as necessidades e desejos } \\
\text { da sociedade de acordo com a sua função social }\end{array}$} & Educação como ensino-aprendizagem \\
\hline & Educa / Se educa \\
\hline & Significação aberta \\
\hline & Acesso como direito à informação e ao entendimento \\
\hline \multirow{5}{*}{ O museu se destina a toda a sociedade } & Memória e identidade no plural \\
\hline & $\begin{array}{l}\text { Patrimônio como ponte de aproximação entre sociedades e culturas } \\
\text { distintas, tempos e espaços }\end{array}$ \\
\hline & Discurso - sinergia entre narrativas múltiplas e multivocalizadas \\
\hline & Comunicação como capacidade de diálogo com o público \\
\hline & Democrático \\
\hline
\end{tabular}

Fonte: Elaboração própria, com adaptações de Cury(2014b), 2019.

Em meio a este paradigma onde o conhecimento é passível de falhas, provisório e em busca da interdisciplinaridade, o museu em transição em sua essência vive uma experimentação e aprendizado, a própria ideia de patrimônio como ideia aberta e em mudança, muitas possibilidades de (re)interpretações, remete a isso. Assim como as afirmações de que se trata de um museu improdutivo, que vive um dilema com a lógica do mercado, tenso, incerto, crítico e contestador são fruto das imperfeições de que se trata o conhecimento deste paradigma.

O museu como instituição plural, em forma, conteúdo, finalidade e público, sustenta-se em uma agenda múltipla, prioriza a diversidade, promove o diálogo entre o local e o global e não se prende as barreiras territoriais. 
Ao afirmarmos que o museu se destina a atender as necessidades e desejos da sociedade de acordo com a sua função social, ampliamos suas responsabilidades, no que tange ao museu em transição apresentado por Cury, destacamos a reciprocidade no processo de ensinoaprendizagem, onde o museu é educador e educando ao mesmo tempo. Esta condição torna-se primordial para que o museu aperfeiçoe o alcance da sua função social, visto que, como colocado anteriormente trata-se de um conceito que está constantemente em aprimoramento.

O museu que se destina a todos, onde todos podem frequentá-lo apresenta-se no museu em transição como um guardião da memória e identidade plural, onde o patrimônio assume a função de ponte de aproximação entre sociedades e culturas distintas, tempos e espaços. No entanto, isso torna-se possível somente porque ao compreender que a boa comunicação está na capacidade de diálogo com o público (e não na simples transmissão de informação) o museu adota um discurso que proporciona uma sinergia entre narrativas múltiplas e multivocalizadas, tornando-se enfim neste quarto paradigma, graças à sua recém adquirida função social, um espaço democrático.

Uma instituição plural em forma, conteúdo, finalidade e público que atende as necessidades e desejos de toda a sociedade, de acordo com a sua função social. Este é o museu do paradigma vigente? Sim e Não.

Assim como o conhecimento, o museu enquanto instituição, é passível de falhas, apresenta-se de formas provisórias e busca na interdisciplinaridade soluções para problemas históricos. Ele vive em experimentação, sendo contraditório em sua essência. Este paradigma apresenta muitos desafios para os museus, Cury (2014b) elege algumas inquietações, dentre elas:

- Como construir as mensagens museológicas agindo dialogicamente?

- Quais seriam as melhores metodologias para as equipes se adequarem para atuar na dimensão dialógica?

- Como disseminar essa nova concepção de maneira a mudar as mentalidades vigentes?

- Como inserir o público nos processos museológicos?

- Como inserir a fala do público na construção do museu?

- Como tornar a fala do visitante constitutiva da instituição? 
Não temos respostas, mas vislumbramos um caminho.

A função social do museu e seu potencial transformador do meio circundante é uma realidade e ao mesmo tempo um desafio. O aprimoramento do seu alcance dependerá da capacidade de o museu dialogar com a sociedade. O que nos leva a um novo e derradeiro capítulo onde vislumbramos os Paradigmas Museológicos Futuros e delineamos novas formas de diálogo entre o museu e a sociedade: Diálogos por meio do Lazer Cultural, da Educação não formal e do Patrimônio Cultural, que em nossa última análise serão determinantes para o futuro da instituição. 


\section{PARADIGMAS MUSEOLÓGICOS FUTUROS: MUSEUS INTERATIVOS, DINÂMICOS E PRESENTES}

Alguns autores apontam que muito antes da Grécia antiga, os museus tiveram sua origem junto com a humanidade, no hábito de guardar coisas. Nesse sentido, o Mouseion seria apresentado como precursor da instituição e não do seu significado. Esta afirmação nos faz refletir sobre o potencial e a profundidade dos museus como guardiões da Musealidade, sendo esta definida como a relação específica do homem com a realidade (DESVALLÉES e MAIRESSE, 2013). Esta responsabilidade não lhe foi atribuída e muito menos por ele fora reivindicada, trata-se de um resultado da sua trajetória paradigmática. Apesar dos repetidos questionamentos, crises de identidades e confrontos institucionais, nas palavras de Bruno (2006):

\footnotetext{
Os museus sobrevivem a estes impactos e ainda ocupam um lugar na formação das novas gerações, na equação que os governos estabelecem entre cultura e desenvolvimento, no cotidiano das pequenas comunidades, na programação cultural dos mais diferentes segmentos sociais dos grandes centros urbanos e representam um item importante na indústria do turismo (BRUNO, 2006, p. 9).
}

Após apresentar e analisar os paradigmas que compõem o passado no segundo capítulo: Greco-Romano, Judaico-Cristão e Ciência Racional; e o paradigma do presente no terceiro capítulo: Atual, ainda sem nome definido; chegamos enfim ao quarto e último capítulo. E o que nos resta diante do passado e do presente postos, senão o futuro? - E o futuro se põe ainda mais desafiador para os museus, o que evidencia a relevância deste debate.

O paradigma vigente resultado dos erros e acertos dos paradigmas antecessores, nos presenteou com a Nova Museologia que por sua vez foi determinante para a consolidação da função social museológica. Mas o que está por vir? - Bruno (2006) no trecho acima citado pontua que os museus "ocupam um lugar" em diversas áreas de nossa sociedade e ao ocupar este lugar o museu assume responsabilidades para com a comunidade em que está inserido, cujo bem estar e satisfação de necessidades várias devem fazer parte de sua missão (SANDELL, 2003).

Oportunamente, na abertura da $15^{\circ}$ Conferência Geral do ICOM, em Haia, Holanda (ISS, 1989) cujo tema era Museologia e futurologia, Neil Postman usa as seguintes palavras: "o 
museu é um farol da consciência social, um historiador do futuro, uma muralha contra a escuridão e o desespero, e um templo de elevação do Homem e, por isso, um museu precisa dialogar com a sociedade" (BRUNO, 2006, p. 9-10, grifo nosso).

Neste capítulo usaremos da temática proposta em Haia (1989), adaptada para Museus e Futurologia, esta última apesar de pouco conhecida é empregada por sociólogos, demógrafos e historiadores e pode ser entendida como uma tentativa de prever, por meio de uma abordagem científica (essencialmente com base no passado e no presente), um futuro remoto (possível, provável, desejável). Sendo assim, com base nos paradigmas do passado e do presente (apresentados e analisados), é hora de esboçar o Paradigma Museológico Futuro.

Mas se o paradigma do conhecimento atual ainda não terminou, como e por que pensar em um paradigma futuro?

Não podemos negar que as últimas décadas em nossa sociedade foram transformadoras. O que dizer dos avanços tecnológicos e informacionais? Das conquistas políticas e sociais de minorias? E das descobertas científicas? - Diante destes e de muitos outros acontecimentos que teriam alterado as bases de nossa sociedade, há autores que concordam com Silverman (1995 apud Silva, 2009, p. 121) e apontam que o paradigma que iniciou no século XX já encontrou o seu fim, "nas últimas décadas a sociedade da informação e do conhecimento tem assistido e participado de uma mudança de paradigma, que responde aos desafios da pósmodernidade e implica a transformação das concepções de conhecimento, comunicação e informação". Neste caso o que vivemos atualmente seria o início de um paradigma novo, ou pelo menos, um momento de transição.

Este debate está em progresso, mas longe de uma afirmação, esta pesquisa busca a reflexão, independente do reconhecimento de estarmos ou não vivendo em um novo paradigma do conhecimento, diante das visíveis mudanças em nosso meio, especialmente no que tange as transformações quanto à natureza da troca de informação e a formação do conhecimento, é de suma importância que o Museu busque entender o que provavelmente continuará e o que poderá plausivelmente mudar em sua própria trajetória.

Museus são mundos complexos, voltados para o lazer e para o aprendizado em inúmeros significados. Como consequência das recentes mudanças em nosso paradigma, os museus chamados por Cury (2014b) de museus em transição, são mais uma vez confrontados e 
convocados a repensar seu papel. O futuro aponta que o museu estático, lúgubre está fadado a desaparecer, um novo perfil da instituição de acordo com a sua função social aponta para um museu interativo, dinâmico e presente. Não estamos dizendo que os museus tradicionais deixarão de existir, sua contribuição para a sociedade foi e ainda será de grande importância. Mas mesmo estes museus terão de se adaptar a este paradigma futuro, a sua forma de dinamismo e interatividade devem ser moldadas a sua função social específica, mas seja como for, ser presente e dialogar com a sociedade é e, continua sendo, uma característica essencial para a sua sobrevivência.

Não existe uma fórmula que leve o museu a perfeição em sua atuação, afinal trata-se de uma instituição dirigida por seres imperfeitos. Além de os museus serem mundos complexos, cada museu tem na sua própria realidade e seus próprios desafios. Alguns trabalham mais com o educativo, muitos focam a preservação, alguns se destinam à pesquisa, outros à celebração artística. Mas todos correspondem a uma parte importante do universo museológico que ao longo da história contribuiu para o desenvolvimento humano. E, no futuro, seja qual for o caminho que o museu seguirá, ele não é dado e não será simples. No entanto, certamente, quanto mais o Museu ampliar seus horizontes e aprimorar as suas formas de diálogo com a sociedade, este caminho será engrandecedor para todos.

\subsection{AS NOVAS FORMAS DE DIÁLOGO ENTRE O MUSEU E A SOCIEDADE}

Uma longa trajetória com a contribuição dos paradigmas museológicos apresentada nos Capítulos iniciais tornou possível encontrar hoje museus que tratam dos mais diversos temas, tais quais: artes; cultura; literatura; história natural; ciências; religião; tecnologia; relíquias; memórias; entre outros. A diversidade dos acervos (antes restritos a itens raros e valiosos em sua confecção) proporciona a diversidade de tipologias de museus, o que desencadeia também a almejada diversidade de público. Esta diversidade aliada à desburocratização para abertura de um museu acomodou um grande número de museus espalhados pelo mundo, o real número atual de museus é praticamente impossível de determinar - seja por país, seja na escala mundial, "se evoca comumente entre 25.000 e 35.000 estabelecimentos reconhecidos oficialmente. O número de instituições que se enquadram na definição proposta pelo ICOM é, obviamente, muito superior" (POULOT, 2013, p.104). 
Com este novo panorama de diversidade de museus e de públicos, como estabelecer um diálogo?

Novos diálogos precisam ser abertos, para que novas práticas sejam encontradas e principalmente para que as finalidades pretendidas pelo museu e apontadas na definição do ICOM: Estudo, Educação e Lazer sejam alcançadas.

Apesar do adjetivo novas, não se trata de algo que não exista. Embora soe como contraditório, as ideias são resgatadas, reformuladas ou eram faladas, porém não ouvidas. Elas apresentam-se novas quando inseridas em um novo contexto.

As ideias preconizadas durante a Mesa Redonda de Santiago do Chile (1972) que colocavam o museu como um espaço privilegiado de educação não formal, especialmente na formação cultural do indivíduo; os princípios fundamentais da Nova Museologia sistematizados pela Declaração de Quebéc (1984) que ampliavam o objeto de estudo da Museologia e consequentemente da práxis museal para a relação Sociedade-Patrimônio-Território; e o balanço da situação dos museus da América Latina que resultou a Declaração de Caracas (1992) apresentando reformulações das políticas de formação e conservação de acervos, de pesquisa, de educação e comunicação são alguns exemplos apresentados durante o capítulo anterior de contribuições para o aprimoramento dos museus. Todavia, algumas ideias presentes nos documentos resultantes destes encontros foram aplicadas, outras se mostraram inviáveis a seu tempo e há ainda as que foram deliberadamente ignoradas.

A viabilidade e a plena implementação de algumas boas ideias aguardam ansiosamente por novas ferramentas, novos atores, enfim, por um novo contexto, e é sob está ótica que o conceito de novo proposto neste item será abordado.

Fazendo uso desta pequena contradição, antes de delinear quais seriam as novas formas de diálogo entre o museu e a sociedade, oportunamente abordaremos agora um conceito que parece não "envelhecer", cuja matriz teórica contribuiu e ainda tem muito a contribuir para o surgimento de novos diálogos e consequentemente de novas práticas: o museu integral.

Apesar de consagrado na Declaração de Santiago (1972), o conceito de museu integral floresce lentamente mediante acontecimentos de fora e de dentro do universo museológico. Quase duas décadas antes de Santiago, Georges-Henri Rivière, museólogo francês e primeiro 
diretor do ICOM (cargo exercido de 1946 a 1962) já apresentava a ideia de integralidade. Não se trata de um tipo de museu, mas sim do próprio existir do museu, assim sendo, todo e qualquer museu pode ser um museu integral.

Neste aspecto concordamos com Scheiner (2012) ao defender que:

\begin{abstract}
O Museu Integral se fundamenta não apenas na musealização de todo o conjunto patrimonial de um dado território (espaço geográfico, clima, recursos naturais renováveis e não renováveis, formas passadas e atuais de ocupação humana, processos e produtos culturais, advindos dessas formas de ocupação), ou na ênfase no trabalho comunitário, mas na capacidade intrínseca que possui qualquer museu (ou seja, qualquer representação do fenômeno Museu) de estabelecer relações com o espaço, o tempo e a memória - e de atuar diretamente junto a determinados grupos sociais (SCHEINER, p. 19, 2012).
\end{abstract}

Como instituição dinâmica de mudança social que o Museu ainda almeja ser, é fundamental que ele estabeleça as relações com o espaço, o tempo e a memória, as quais se refere Scheiner (2012), somente assim ele poderá ser ele também um agente de mudança social, levando em consideração a totalidade dos problemas da sociedade e proporcionando à comunidade uma tomada de consciência do seu próprio meio social, econômico e político.

O conceito de um museu integral conecta-se ainda com a proposta do novo lugar metodológico apresentada por Cury (2014), exposta anteriormente na Figura $7^{25}$, cuja ideia central relembramos, seria de que o objeto de estudo da Museologia estender-se-ia do tripé Homem - Objeto - Cenário para o entendimento da relação Homem/Sociedade - Objeto/ Patrimônio - Cenário/Território. Ou seja, o museu integral nada mais seria do que a práxis museal mais próxima do que é proposto pela Museologia.

Com o passar dos anos, a ideia do museu integral oficializada em Santiago enfraqueceu, dando lugar a tipologias de museus com propostas semelhantes, como os ecomuseus, museus de território e museus comunitários. Apesar da inestimável contribuição que essas novas modalidades de museu representam, suas ações isoladas deixam a seguinte reflexão: será que o futuro da instituição está garantido com uma parcela dos museus atuando de forma integral sob o manto da Nova Museologia, enquanto outros tantos permanecem envoltos em si próprios e alheios à realidade que os cerca?

\footnotetext{
${ }^{25}$ Figura disponível na página 70 desta pesquisa.
} 
A partir do reconhecimento da função social dos museus, entendemos que o museu integral é, ou pelo menos deveria ser, o modus operandi de todo e qualquer museu, seja ele tradicional ou não, global ou local. Partindo da ideia de que todo museu pode ser integral, percebemos que também é possível que todo museu seja um museu integrado, no sentido de que a sua existência não faz sentido de forma isolada.

Entendemos, portanto, que o museu, cuja razão de sua existência esteja fundamentalmente no constante aprimoramento de sua função social, seja antes de tudo um museu integral que habite de forma integrada com a sociedade e, para que isso ocorra, o diálogo torna-se uma condição obrigatória para o seu existir. Diante dessa possibilidade, pontuamos que compreendemos que ainda hoje emergem inúmeras adversidades para que isso se torne realidade. O que nos faz retomar o questionamento antes proposto: Diante do novo panorama de diversidade de museus e de públicos, como estabelecer um diálogo?

Compreendemos, também, que os meios de comunicação são inúmeros e particulares a cada realidade e propósito, visto que cada museu em seu contexto social torna-se um ambiente único e complexo. Necessariamente, o que prospera em um ambiente pode tão somente não dar certo como pode corroer o outro, fazendo com que suas ações ocorram quase que de forma experimental. Ainda assim, para que o Museu prospere em sua função social em um futuro próximo, faz-se necessário que ele estabeleça algumas vias de comunicação com a sociedade, as quais apontamos: o Lazer, a Educação e o Patrimônio; para que nessas vias possam acontecer os diálogos são fundamentais...

\footnotetext{
E o que é o diálogo? É uma relação horizontal de A com B. Nasce de uma matriz crítica e gera criticidade (Jaspers). Nutre-se do amor, da humildade, da esperança, da fé, da confiança. Por isso, só o diálogo comunica. E quando os dois polos do diálogo se ligam assim, com amor, com esperança, com fé um no outro, se fazem críticos na busca de algo. Instala-se, então, uma relação de simpatia entre ambos. Só aí há comunicação (FREIRE, 2011, p. 141).
}

Acreditamos, assim como o mentor da Educação para consciência, o educador brasileiro Paulo Freire, que só o diálogo comunica e gera conhecimento. Posicionemos nesta relação horizontal proposta por Freire (2011) o Museu como A e a sociedade como B. A ligação de ambos em busca de algo, digamos do desenvolvimento, geraria a criticidade. E esta, por sua vez, potencializaria o próprio desenvolvimento recíproco, tudo por meio do diálogo. 
As análises feitas do passado, no capítulo dois, e do presente, no capítulo três, nos permitiram que, neste quarto capítulo delineássemos a perspectiva de três novas formas de diálogos do museu com a sociedade, diálogos estes, que a nosso ver, fazendo uso da criticidade e do desenvolvimento recíproco, favoreceriam o alcance das três finalidades prima do museu (estudo, educação e lazer) e, consequentemente, por meio do aprimoramento de sua função social, culminariam no desenvolvimento da sociedade. São eles: Diálogos por meio do Lazer Cultural, Diálogos por meio da Educação Não Formal e Diálogos por meio do Patrimônio Cultural, os quais apresentaremos na sequência sob a seguinte ótica: Do que se trata os conceitos (Lazer Cultural, Educação Não Formal e Patrimônio Cultural); Em que momento durante os paradigmas do conhecimento eles convergem para o universo museal; Como eles são entendidos nos museus do paradigma atual; e por fim como essa relação pode ser estabelecida em um futuro, a fim de aprimorar o alcance da função social do Museu. Assim, vejamos.

\subsubsection{Diálogos por meio do Lazer Cultural}

Pressupondo que ir a um museu é quase sempre uma escolha, iniciamos este item incitando mais uma reflexão: o que leva as pessoas ao museu?

Pensar no museu como uma possibilidade, é torná-lo uma opção. Mas uma opção de que?

De lazer.

Com exceção dos pesquisadores e das visitas escolares "obrigatórias", o que leva a maioria

das pessoas ao museu é o lazer. À vista disso, na sequência abordam-se conceitos de lazer e, para esclarecer esta afirmação, articula-se com a finalidade do museu, conforme os paradigmas.

Apesar de quase sempre estar associado a atividades que nos remetem a divertir-se, recrear-se e entreter-se, o lazer ocupa um lugar político, cultural, social e educativo muito importante na história das sociedades. Para longe da sua face mais conhecida, lembramos que o lazer, ao longo do tempo, foi, diversas vezes, usado como ferramenta política de manipulação social, portanto, apesar de importante, seria ingênuo de nossa parte encarar o lazer somente por sua 
vertente mais conhecida, o que nos leva, primeiramente, à necessidade de apresentar alguns dos desdobramentos desse conceito.

O termo lazer sempre foi utilizado de forma vaga por diferentes precursores. Iniciamos por Aristóteles e a noção de scholé, palavra que significava, simultaneamente, lazer e educação de si mesmo, "um tempo que se situava entre a prática ativa do cidadão pela gestão da cidade e a prática dos cultos". Aristóteles afirmava que "A paz é o fim último da guerra, e o lazer [scholé] o da vida ativa" (CAMARGO, 2001, p. 237), pontuando, contudo, que não havia lazer para os escravos. Séculos mais tarde a civilização cristã do Ocidente acabou por inverter alguns dos valores das sociedades anteriores. Santo Agostinho, no séc. IV d. C., alertava para os perigos do lazer, colocando a dimensão lúdica da vida assentada pelo prazer como um contraponto à dimensão séria da vida, pautada pelo trabalho e pelo dever (CAMARGO, 2001).

Já no século XIX, são inúmeras as contribuições publicadas, ampliando vertentes e significados: o manifesto $O$ direito à preguiça, que criticava as jornadas de trabalho a qualquer preço, do médico caribenho, militante socialista e genro de Karl Marx, Paul Lafargue (1842-1911), escrito durante a sua prisão em Paris; Leisure Theory Class $^{26}$, do filho de um emigrante norueguês nos Estados Unidos, Thorstein Veblen (1857-1929), que diante da pujança da indústria americana, expõe ao mundo o consumo do lazer ostentatório como símbolo da distinção social das classes dominantes. Além das contribuições de David Riesman (1909-2002) e a explosão do Lazer moderno, David Friedman (1945-) e o mal-estar do homem no trabalho industrial e Roger Caillois (1913-1979) e as categorias do jogo (CAMARGO, 2001).

Podemos notar que as investigações sobre o tema lazer no cenário internacional a partir da segunda metade do século XIX possuíam um interesse específico no tempo liberado do trabalho, quando não há obrigações profissionais. Esse sentido foi ampliado a partir de 1930, quando o tema passou a ser concebido também como as distrações e ocupações, às quais os indivíduos poderiam se entregar de espontânea vontade durante o tempo não ocupado pelo trabalho.

\footnotetext{
${ }^{26}$ Teoria da classe ociosa (São Paulo: Pioneira, 1965).
} 
A partir de uma nova concepção do tempo liberado do trabalho, o tempo livre dos trabalhadores e operários, principalmente, nas sociedades urbanas e industriais, como os Estados Unidos passaram a ser de interesse de uma nova área de pesquisa, chamada de sociologia do lazer (GOMES e MELO, 2003). Em certa medida, as conquistas sociais e a constante diminuição das horas trabalhadas desde o início do século XX também ressaltavam a necessidade de estudos sobre as formas de gastar o tempo liberado do trabalho.

Em um contexto brasileiro, o lazer como campo de estudo científico tem início a partir da década de 1970 sob influência das investigações sobre a sociologia empírica do lazer do sociólogo francês Jofre Dumazedier (1915-2002). Os expoentes dessa temática foram as recorrentes visitas de Dumazedier à UNB (Universidade de Brasília) e os seminários promovidos pelo SESC (Serviço Social do Comércio) nos anos 1960 e 1970. Com isso, as contribuições de Dumazedier, de acordo com Camargo (1998), os estudos sobre lazer deixaram de ser um tema tratado apenas empiricamente, estimulando, a partir de então, pesquisas cientificas sobre este tema.

Segundo o sociólogo, esses estudos vieram a colaborar substancialmente com uma possível teoria empírica do lazer. No entanto, é fato que o lazer é uma prática social que implica no tempo de não trabalho, ou seja, só conquistamos o momento de lazer quando estamos dispensados das atividades profissionais e das nossas necessidades pessoais, desenvolvidas no tempo liberado do trabalho, ou no tempo livre ou disponível, não só das obrigações profissionais, mas também das familiares, sociais e religiosas (MARCELLINO, 2000).

Em uma concepção sobre o conceito de Lazer, Dumazedier aponta que:

Lazer é um conjunto de ocupações às quais o indivíduo pode entregar-se de livre vontade, seja para repousar, seja divertir-se, recrear-se e entreter-se, ou ainda para desenvolver sua informação ou formação desinteressada, sua participação social voluntária ou sua livre capacidade criadora, após livrar-se ou desembaraçar-se das obrigações profissionais, familiares e sociais (DUMAZEDIER,1973, p. 34).

O autor em sua definição nos apresenta as múltiplas faces do lazer desde as mais conhecidas: diversão; recreação e entretenimento, até as mais distantes do imaginário popular: formação; criação e participação social. Ambas as vertentes possuem igual valor e em absolutamente nada deveriam antagonizar, ao contrário, a esfera educativa do lazer implica ludicidade, assim 
como, a esfera lúdica do lazer evoca o seu carácter educativo. É importante notar aqui que as três funções apontadas por Dumazedier: a do divertimento, do desenvolvimento pessoal e a do descanso coexistem intrinsicamente em qualquer atividade de lazer, alternando-se somente quanto à predominância de uma sobre as outras.

Nesse sentido, é em meio a esta dinâmica que o museu se apresenta, e é diante dela que ele pode proporcionar ao seu público momentos lúdicos e enriquecedores, despertando reflexões construtivas que ultrapassarão o momento da visita e que acompanharão o visitante por toda a sua vida.

Alguns conceitos e definições também relacionam os aspectos culturais e educacionais, de recreação e de liberdade criativa do tempo de lazer, como nos conceitos apresentados pelos seguintes autores:

- Godbey (1990, grifo nosso), “ter lazer é um dos sonhos mais acalentados dos seres humanos, livre do interminável mundo das obrigações, livre para buscar aquilo que queremos e investir o tempo de maneira voluntária e prazerosa, livre para encontrar e aceitar seu lugar no mundo, enfim, livre para existir em estado de graça”.

- Camargo (1992), Lazer é: "um conjunto de atividades gratuitas, prazerosas, voluntárias e liberatórias, centradas em interesses culturais, físicos, manuais, intelectuais, artísticos e associativos, realizadas num tempo livre roubado ou conquistado historicamente sobre a jornada de trabalho profissional e doméstico e que interferem no desenvolvimento pessoal e social dos indivíduos".

- Bramante (1998, grifo nosso), “o lazer se traduz por uma dimensão privilegiada da expressão humana dentro de um tempo conquistado".

- Marcelino (2000, grifo nosso), “deve-se levar em conta que, se o conteúdo das atividades de lazer pode ser altamente "educativo", também a forma como são desenvolvidas abre possibilidades "educativas" muito grandes, uma vez que o componente lúdico, do jogo, do brinquedo, do "faz-de-conta", que permeia o lazer é uma espécie de denúncia da "realidade", deixando clara a contradição entre obrigação e prazer". 
- Gomes (2004), "lazer é uma dimensão da cultura constituída no tempo/espaço conquistado pelo sujeito ou grupo social, estabelecendo relações dialéticas com as necessidades, os deveres e as obrigações - especialmente, com o trabalho produtivo".

A partir destes significados, devido ao caráter não tão longínquo de ser sinônimo de um local grandioso, restrito e lúgubre, até pouco tempo atrás era difícil compreender o museu como uma opção aberta de lazer, e que uma pessoa livre para buscar aquilo que quer, entre diversas opções escolheria um passeio ao museu? - Ainda mais se pensarmos que o tempo que ela gastará durante este passeio, foi um tempo arduamente conquistado em anos de batalhas sociais, políticas e trabalhistas, fazendo-nos refletir sobre a responsabilidade da instituição escolhida corresponder à confiança nela depositada em preencher esse precioso tempo.

O componente lúdico que permeia o lazer, quase que indissociável da palavra, invariavelmente, vela o fato de que o conteúdo das atividades de lazer pode ser altamente educativo, é o que ocorre com as atividades desenvolvidas em museus, cada vez mais lúdicas ao passo que também apresentam-se cada vez mais educativas. Isso se deve em grande parte ao fato de que nas últimas décadas as instituições museais exploram mais formas de como desenvolver possibilidades "educativas", proporcionando aos seus visitantes a vivência lúdica de manifestações culturais.

Rememorando a trajetória paradigmática apresentada no segundo e terceiro capítulos, faremos uma reflexão para compreender em quais momentos o lazer converge para o mundo museal.

Entendemos que o Lazer é um conceito moderno, como dito anteriormente, suas primeiras investigações datam da segunda metade do século XIX. Portanto, essa inflexão ao passado usa de uma licença poética para evidenciar os pontos de convergências dos atributos do que hoje entendemos como lazer, com as características do que no passado compreendia-se como museu.

Observemos a relação lazer-museu ao longo dos paradigmas do conhecimento sob a ótica de quem o frequentava (Quadro 6). A partir desse recorte, podemos suscitar as motivações que levavam estas pessoas ao museu. 
Quadro 6: Destaque referente a quem se destinava o Museu em cada paradigma do conhecimento

Paradigma A quem se destina? Quem o frequenta?

$\begin{array}{lll}\text { Greco Romano } & \text { Eruditos Gregos (Greco) } & \begin{array}{l}\text { Estudiosos de diversas áreas do saber e } \\ \text { diferentes nacionalidades (Romano) }\end{array}\end{array}$

Judaico Cristão Ao círculo social da nobreza (nobreza)

Inicialmente, exclusivamente ao clero e posteriormente também aos fiéis (Clero)

Ciência Racional Artistas, eruditos e estudiosos

Atual Toda a sociedade

Fonte: Elaboração própria, 2019. Adaptado dos quadros 1, 2, 3 e 4 desta pesquisa.

Os visitantes do antigo Mouseion do paradigma Greco-Romano, os eruditos gregos, de acordo com Suano (1986) procuravam-no como um lugar de repouso da mente, onde o pensamento podia ser profundo e criativo, liberto dos problemas e aflições cotidianos. Não podemos negar que tais características assemelham-se à vertente do repouso apontada como uma face do lazer por Dumazedier (1973). Já o grande complexo cultural de Alexandria, frequentado por estudiosos de diversas áreas do saber, pelos mais destacados sábios, artistas e poetas do mundo grego e egípcio, evoca certa semelhança com um local que proporcionava a informação e a formação desinteressada, outra característica do lazer contemporâneo, apontada pelo sociólogo.

Após quase perder-se, a noção de Museu no paradigma Judaico-Cristão, apoiou-se no colecionismo, o que sustentou a instituição e, séculos mais tarde, serviu de fonte para os acervos de inúmeros museus pelo mundo. E o hábito de colecionar, além de espelhar grandeza e afirmação social para os membros da nobreza, também se constituiu pelo simples fato de ser uma atividade prazerosa e divertida para o colecionador, remetendo à outra face do lazer. Ao voltar-se para artistas, eruditos e estudiosos, o museu do paradigma da Ciência Racional, apresentado inicialmente no formato dos gabinetes de curiosidades e das grandes galerias palacianas, também usufruía da premissa de existência pelo e para o deleite de seu colecionador. 
O início do paradigma atual, enfim, nos apresentou a intencionalidade da relação lazer-museu. Com a criação de um número razoável de novos museus, a diversificação de tipologias e o surgimento de museus pequenos e regionais, a partir do século XIX, o museu passa a ser visto e frequentado como um local de lazer, ainda para um público restrito. Foi somente após as modificações ocorridas pós-movimento da Nova Museologia, juntamente com as transformações sobre o entendimento do conceito de Lazer que, agora destinado a toda a sociedade, o museu passa a incorporar, em seu dia a dia, ações que o posicionam como uma opção de lazer, diversificando suas ações bom como o uso de seu espaço.

Após este recorte de pequenas aproximações ao longo da trajetória museológica, vejamos, então, como as mudanças mais recentes no conceito de Lazer afetaram a sua relação com o museu contemporâneo.

Ao longo do século XX o tempo livre conquistado abriu a oportunidade de novas formas de lazer, mas que, no caso do desenvolvimento das sociedades urbano-industriais em direção a uma sociedade moderna, culminou rapidamente pela cultura do consumo de massa e assim perdeu, em certa medida, o que Dumazedier aconselha quando ressalta que a prática do lazer deveria ser um momento de informação e formação pessoal desinteressada e criativa, e não de consumo exagerado e, por vezes, alienante.

Ainda que possamos afirmar que o tempo livre para o lazer, o ócio propriamente dito, surgiu na era industrial, também temos que considerar que o lazer caracterizou-se pelos desdobramentos dessa sociedade moderna (DIAS, 2009). Nesse caso, consideramos o lazer como um fenômeno social da sociedade moderna, e a sua prática está relacionada ao seu amplo aspecto cultural. Para Gomes e Melo (2003), a cultura se tornou o foco central no campo do lazer, especialmente, na prática social do lazer. Nesse sentido, analisamos a cultura no contexto das suas modificações ao longo do século XX, quando o avanço tecnológico fortaleceu uma cultura de massa, que se transformou rapidamente no que hoje conhecemos como Indústria Cultural (MORIN, 1977; HORKHEIMER e ADORNO, 1997).

Para Horkheimer e Adorno (1997), na Indústria Cultural quase tudo se torna uma espécie de negócio com fins estritamente comerciais, o que contribui para a lógica do consumo exagerado. Morin (1977) por sua vez, corrobora os pensamentos dos autores, ao afirmar que o desenvolvimento tecnológico impulsionou a busca pelo lucro imediato também na esfera da 
cultura. Essa Indústria Cultural, quase que de forma virulenta, atingiu as camadas sociais, com um conteúdo cultural amplamente variado e disseminado pelas redes de comunicação de massas.

Horkheimer e Adorno (1997) apostam na ideia de que a cultura, enquanto componente da Indústria Cultural é moldada e vendida como forma de manipulação das massas, inserida no modo de produção capitalista, ela é difusora da ideologia dominante. E o indivíduo, nesse conteúdo massificante, é manipulado de forma alienante até mesmo em seus momentos e espaços de lazer, forçado ao consumo de um lazer quase obrigatório pelo status que este proporciona, transformando esses espaços e momentos, devido à obrigatoriedade, em uma espécie de extensão do seu trabalho. Indubitavelmente, a Indústria cultural massificada caminhou lado a lado com as questões do lazer no século XX, moldando as características de uma sociedade que passou a consumir lazer e se apoderou do nosso tempo livre (KRIPPENDORF, 2001), ocasionando uma verdadeira transformação do "homem de lazer" para o "homem-consumidor".

A indústria cultural do lazer massificado e alienante oferece satisfações ao "homemconsumidor" ao passo que ela mesma cria expectativas e desejos correspondentes na escala do consumo e impondo à sociedade necessidades antes não primordiais. O Consumo massificado da cultura e do lazer em nossa sociedade não caracteriza o que Dumazedier (2004) considera como formação desinteressada ou como um possível Ócio Criativo, de Domenico de Masi (1997), ao contrário, cada vez mais vivenciamos práticas de lazer alienantes e estressantes, com o tempo cronometrado pela atividade e não pelo tempo de apreciação do indivíduo, em quantidades absurdas, visando à quantidade de consumo de atividades e não à profundidade da experiência, com o foco no consumo e não na vivência do indivíduo.

Assim como as demais instituições provedoras de lazer, o museu viveu e ainda vive um dilema de posicionamento. Sem a proteção financeira da elite e da burguesia, o museu viu-se aflito por visitantes, visto que, o esvaziamento de público no século $\mathrm{XX}$ representou o fechamento e sucateamento de muitos museus. Em uma tentativa de manter-se vivo em um mundo globalizado, Cury (2014) indica características do museu contemporâneo ao qual ela nomeia museu em transição: 


\begin{abstract}
Nega o museu tradicional, reconhecendo alguns dos seus limites, mas vive o momento da globalização, da indústria do entretenimento e da satisfação gerada por ela, o reducionismo e a simplificação da diversidade cultural, a negação das minorias, pois não se enquadram plenamente na esfera pública definida pelo capitalismo, vivem a desterritorialização, negam estéticas que venham a questionar uma visão econômica de desenvolvimento (CURY, 2014b, p. 65, grifo nosso).
\end{abstract}

A Indústria Cultural do Lazer massificado encontrou no museu um componente valioso para satisfazer as necessidades culturais de seu público, e os museus, por sua vez, vislumbraram nessa indústria uma saída para encher seus corredores, ainda que, para isso, a qualidade (principalmente educativa) de suas atividades, em alguns casos, seja um tanto questionável, caindo em armadilhas como o reducionismo e simplificação da diversidade cultural, caminhando na contramão da função social museológica, chegando ao ponto de como apontado por Cury, negar as minorias que não se enquadram na esfera pública definida pelo capitalismo, ou seja, invisíveis pelo não potencial de consumo.

Em decorrência disso, desde o final do século XX, presenciamos o surgimento de museus "esvaziados de conteúdo", não estamos falando de quem ou o que é exposto, mas sim da qualidade e até mesmo da inexistência das ações museológicas; de museus criados a partir de interesses políticos e não da sociedade; de museus cuja arquitetura sobrepõe e até desestimula a visita ao seu interior; de museus que voltam suas ações exclusivamente para o turista inibindo a comunidade local; em suma, estamos falando dos museus que vislumbram apenas números e grandes filas deixando de lado a sua complexa função social (SCHEINER, 2017).

Permanecemos presenciando tais conflitos, e o universo museológico está vivenciando experimentações. Cury (2014b), enxerga mudanças "o museu, me parece, quer superar deficiências e limites" (CURY, 2014b, p. 64). Certamente há muitos desafios para as instituições museológicas manterem-se vivas, interativas, dinâmicas e presentes, no entanto, sem perder a sua essência. Sim, lembramos que o museu do paradigma atual destina-se a atender as necessidades e desejos da sociedade, e a necessidade e o desejo pelo lazer nos últimos anos é cada vez mais ascendente, mas, colocar-se a serviço de algo, não significa não questioná-lo. Nesse caso, compete ao museu, por meio do diálogo com a sociedade, analisar se tais necessidades são reais ou criadas pelo viés da manipulação social, e a partir disso 
buscar sim atendê-las, mas não necessariamente da maneira que a sociedade quer e sim da maneira que a sociedade realmente precisa para o seu desenvolvimento justo.

Mais do que uma necessidade e uma reinvindicação, o lazer tornou-se um direito da pessoa, que passa a vivenciá-lo como um valor. Além do direito ao lazer, no caso brasileiro, é garantido também o acesso aos bens culturais e equipamentos de lazer. Segundo a nossa Constituição, é dever do Estado fornecer subsídios e fomentar o lazer, a educação e a cultura. Evidencia-se ainda mais a importância do lazer em nossa sociedade, colocado ao lado da educação e da cultura como um direito e um importante promotor de dignidade humana.

A conquista do direito ao lazer é um marco em nossa sociedade, ainda que não represente a totalidade do acesso democrático a este. Infelizmente, no caso brasileiro, as grandes desigualdades sociais e a segregação socioespacial, características da nossa sociedade, nem ao lazer mercadoria os mais pobres têm acesso. Conforme Aulicino (2011), o lazer no contexto da sociedade do consumo e da Indústria Cultural se transforma em mais uma dimensão da desigualdade social, na medida em que exposto exclusivamente à condição de quase mercadoria, impõe restrições às populações mais pobres.

Os espaços urbanos nas médias e grandes cidades, por exemplo, são esvaziados e cooptados pela especulação imobiliária - muros altos e grades relegam as opções de lazer aos espaços artificiais dos condomínios fechados. O lazer nos espaços abertos da cidade são quase inexistentes, resumindo-se aos shoppings Centers em todo seu status de paraíso do consumo. Com exceção de alguns lugares simbólicos, como as praças (muitas em situação de abandono), parques (mal distribuídos geograficamente, concentrados em uma área e ausentes em outras) e as ruas de lazer, que principalmente nas periferias surgem de forma espontânea e resistem a diversas ameaças como a violência urbana.

Se, de um lado, os centros urbanos foram esvaziados de opções de lazer, de outro lado, nas distantes periferias faltam atrativos, principalmente, os de lazer cultural. Aulicino (2011) diz que a falta de espaços de lazer é preocupante e, citando o trabalho de Dumazedier (2004), Aulicino (2011, p. 4) afirma que "o lazer é, na atualidade, um instrumento de inserção e de distinção social". O distanciamento dos museus das regiões periféricas brasileiras é latente, resultado de uma construção histórica segregadora. Apesar das recentes aberturas de museus nestas regiões (principalmente de museus comunitários), a distância desta instituição no 
cotidiano desta parte da sociedade ainda é alarmante. Mas o caminho já foi aberto, uma referência de que a presença dos museus nas regiões periféricas não é só importante, como também viável, está no grande número de centros culturais nestas regiões, que vivem cheios e repletos de atividades, demostrando a disposição e a ânsia por cultura das periferias brasileiras.

Após anos de consagração como espaço elitizado, este talvez seja o grande desafio do museu contemporâneo, tornar-se um espaço de "inserção" e não de "distinção social". As diversas transformações ocorridas a partir do movimento da Nova Museologia favoreceram essa ruptura de "templo da elite", para "espaço da diversidade" tanto na representação de seu acervo quanto em seus visitantes, mas muito ainda terá de ser feito para que os espaços culturais como os museus, especialmente no caso brasileiro, sejam convidativos a todos os públicos, a barreira existente entre as características desses locais pode e deve ser transposta.

Assumidamente, uma instituição que existe (também e não somente) para fins de lazer, o museu contemporâneo, parece ainda viver o dilema, havendo uma contradição entre o que a instituição e a sociedade almejam e o que de fato os museus apresentam. De um lado existem os museus que se posicionam como atrativos, e até aqueles que foram criados como tal, focados especialmente no atendimento da finalidade do lazer. Do outro lado, há os museus que se dedicam as finalidades do estudo e da educação e que, propositalmente, não se posicionam como uma instituição de lazer. Entre essas duas vertentes, há ainda aqueles que, por falta de investimento (financeiro e de pessoas), e até mesmo de vontade, não se posicionam nem de uma forma nem de outra, apenas existem.

Mas será que esta coexistência entre os museus que se voltam ao lazer e os museus que se dedicam ao estudo e à educação, cada qual exercendo uma finalidade é suficiente para o alcance da função social museológica? Neste ponto acreditamos que, em um paradigma museológico futuro, que aponta para museus interativos, dinâmicos e presentes, essa separação de finalidades poderá afetar a existência de ambos.

Os museus dedicados ao lazer que ignoram os seus fins de estudo e de educação, apresentamse como grandes "cascas" vazias de conteúdo, procurados, geralmente, por turistas somente pela ostentação de seu consumo eles já são alvos de inúmeras críticas por viverem na desterritorialização e negarem ou ignorarem o debate social, tornando-se assim mais um 
instrumento de alienação do indivíduo. Por sua vez os museus dedicados ao estudo e à educação, que ignoram a sua finalidade de lazer, também recebem muitas críticas pelo fato de eles próprios alienarem-se do público, distanciando-se da diversidade e restringido o acesso ao conhecimento (SCHEINER, 2017).

Para que essa barreira entre as finalidades museológicas: estudo, educação e lazer, possa ser superada, novos diálogos por meio do lazer cultural podem e devem ser abertos, permitindo o aprimoramento das ações existentes e somando novas contribuições. Os desafios postos ao museu pelo lazer encontram no diálogo entre o museu e a sociedade, por meio do próprio lazer, a sua melhor chance de aprimoramento.

A fim de que isso ocorra, é necessária, primeiramente, a diversificação dos profissionais atuantes em museus, com formação equivalente às diferentes finalidades a que o museu deve atender, portanto, além dos museólogos, historiadores e antropólogos, estamos falando da importância da presença de pedagogos, psicólogos, turismólogos, administradores, sociólogos, mercadólogos, entre outros, na composição do quadro de funcionários (no caso dos que possuem estrutura e estímulo financeiro para tal), ou mesmo como contribuição externa na elaboração do plano museológico (no caso dos museus que não possuem estrutura própria de pessoal e de recursos).

Esta transversalidade do conhecimento é fundamental para transpor a barreira hoje existente entre os museus voltados para o lazer e os museus voltados para o estudo e a educação, possibilitando aos museus conhecidos como "atrativos" o preenchimento de suas ações com conteúdos educativos ao passo que democratizaria o acesso ao conhecimento gerado pelos museus com fins de estudo e educação.

Superado este grande obstáculo estrutural, não haveria mais uma separação entre os museus, toda e qualquer instituição museológica existiria e voltaria a sua função social para fins de lazer, estudo e educação. Haveria espaço, então, para o devido e correto uso de algumas estratégias que podem auxiliar na aproximação do público com as práticas e as finalidades museológicas, uma delas é a exposição temporária, que pode ser uma mostra inédita no museu, com peças de várias instituições e coleções ou até mesmo uma exposição inteira vinda de outra instituição, mas também pode ser uma exposição organizada de forma mais objetiva a partir do próprio acervo do Museu. Ademais, ela é citada por Santos como: 
Possuidora de caráter provisório que objetiva uma apresentação mais específica e pode ampliar informações dos aspectos abordados na exposição permanente, porém, não obrigatoriamente. Ela dá um tratamento mais amplo aos objetos, podendo os mesmos serem abordados também pelos aspectos estéticos, artísticos, científicos, entre outros (SANTOS, 2000, p.130).

A exposição temporária possibilitaria a oportunidade de o Museu se renovar, sem perder sua identidade. Isso significa adotar procedimentos que instiguem o público em geral a apreciar o Museu, conhecendo também o seu acervo. Portanto, não estamos falando de modificações relacionadas à identidade do museu, mas da utilização da exposição temporária como uma estratégia valiosa de posicionamento e de ação.

Para que o museu tenha a oportunidade de alcançar a sua função social, antes de tudo, ele precisa conquistar a atenção do indivíduo, convidá-lo a frequentá-lo, despertando a sua vontade muitas vezes pela curiosidade. O diálogo por meio do lazer, ao utilizar as exposições temporárias de forma estratégica, alcançaria um maior número de pessoas, tanto de turistas quanto da própria comunidade que renovaria o seu interesse, já que essa modalidade de exposição pode abordar diversos temas com uma variedade de formatos, o que faz com que alcancem diferentes públicos com diferentes gostos e motivações.

No entanto, para o melhor aproveitamento dessa estratégia, a exposição temporária não deve ser encarada e concebida como uma atividade única, que tem fim em si mesma, sendo importante apenas no curto espaço de tempo em que ela é apresentada, mas sim como uma ação que pode ser associada às expectativas da sociedade e as finalidades do museu, que ainda, se acrescidas de características itinerantes, ampliam o raio de atuação do elemento difusor de informações (a exposição) e ampliam o conhecimento sobre a cultura e o próprio museu.

Com base nos apontamentos de Vasconcellos (2006), o termo exposição temporária já não é considerado novidade em muitos países como a França, Inglaterra, Espanha, Estados Unidos e México, entretanto, a consolidação dessa ação, assim como o seu uso de forma estratégica e inteligente pelos museus brasileiros é uma realidade recente e pouco estudada, mas que já mostra grandes resultados. Assim como o diálogo por meio do lazer, não se trata de uma novidade, mas sim de algo ainda não devidamente explorado. O aprimoramento desse diálogo 
e o uso dessa ação estratégica não somente é possível como já acontece, um exemplo das suas possibilidades é o Museu da Imagem e do $\operatorname{Som}^{27}$ de São Paulo, o MIS.

Inaugurado em 1970, seu acervo possui mais de 200 mil itens, como fotografias, filmes, vídeos e cartazes e é atualmente um dos mais movimentados atrativos da cidade de São Paulo. Além de grandes exposições nacionais e internacionais, o MIS oferece grande variedade de programas culturais, com eventos em diversas áreas e para diferentes públicos: cinema, dança, música, vídeo e fotografia estão presentes na programação diária do Museu. No entanto, o MIS nem sempre se posicionou dessa maneira, inicialmente, em sua criação, a sua finalidade era a de um museu que preservasse e produzisse imagem e som da cidade de São Paulo, conceito este que tomou forma após a inauguração do MIS do Rio de Janeiro. Com o passar dos anos, desempenhou um importante papel de valorização da memória histórico-cultural da capital paulista, mas vagarosamente caiu no esquecimento do grande público.

\begin{abstract}
Entre os anos de 1990 e 2008, enquanto assistíamos à emergência das novas mídias tecnológicas e à expansão da arte para práticas híbridas, tornou-se necessário reinventar o MIS, sem perder de vista o seu patrimônio já constituído. Seguindo o desenvolvimento da arte contemporânea e preocupado com uma visão crítica sobre essa nova produção, o Museu da Imagem e do Som lançou-se no desafio de adequar seu conceito institucional e sua estrutura física, sempre buscando integrar memória e contemporaneidade. (MIS, 2019)
\end{abstract}

Após a sua reabertura em 2008 "inteiramente renovado para ser um museu público pronto para dialogar com a arte do século 21" (MIS, 2019), o MIS conseguiu transpor o estigma de "museu arquivo" com o qual ficara rotulado, para transformar-se em um museu interativo, dinâmico e presente, cujo lazer proporciona momentos enriquecedores de formação pessoal aos seus visitantes, seus gestores souberam oferecer visibilidade e audiência às boas obras de artes plásticas, cinema, vídeo, fotografia e música, sem deixar de lado a rica história acumulada desde os anos 1970 e, principalmente, sem deixar de atender à documentação e à conservação de importantes legados artísticos de imagem e som (MIS, 2019).

Responsável por exposições temporárias de enorme sucesso de público como "Kubrick" de 2013 (60 mil visitantes), "David Bowie" de 2014 (80 mil visitantes), "Castelo Rá-Tim-Bum" de 2015 (410 mil visitantes), "Tim Burton” de 2016 (213 mil visitantes), o MIS foi um dos

\footnotetext{
${ }^{27}$ Para mais informações acessar: https://www.mis-sp.org.br
} 
responsáveis pelo que foi chamado pela publicação de língua inglesa The Art Newspaper como o "boom brasileiro". Em 2014 sete exposições brasileiras figuravam entre as 20 exposições mais visitadas em todo o mundo (IBRAM, 2019) e, desde então, é comum encontrar o nosso país entre os destinos expoentes do Turismo Cultural. Entretanto, o sucesso do MIS como uma instituição cultural voltada ao lazer não se restringe ao turista, ao contrário, o seu novo posicionamento impactou diretamente na reaproximação da comunidade e não somente a de seu entorno (MENDES 2014).

Figura 10: Exposição Castelo Ra-Tim-Bum no MIS em 2014

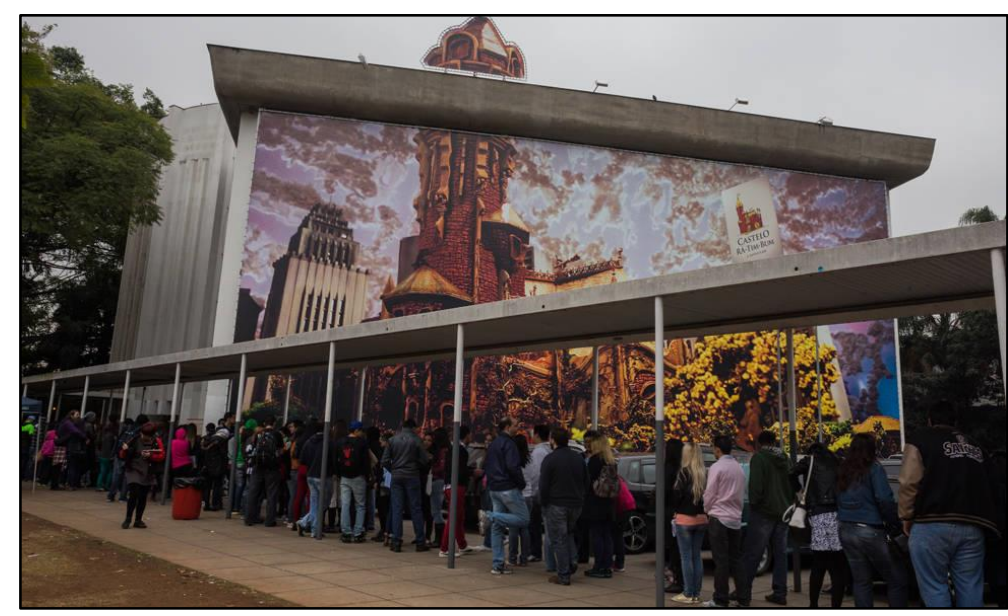

Fonte: Folha de São Paulo, 2014

A exposição "Castelo Rá-Tim-Bum” (Figura 10) demostrou o potencial das exposições temporárias. Com uma temática de alcance popular e, ao mesmo tempo, condizente com a missão de um museu cuja existência orbita a temática da imagem e do som, a exposição aguçou a curiosidade de muitas pessoas, mexendo com memórias de infância de diferentes gerações, posicionando definitivamente o MIS na vida dos paulistanos. O resultado segundo Mendes (2014) foram filas imensas e uma espera de aproximadamente quatro horas, o que despertou estranhamento, chegando a chamar atenção da mídia por se tratar de um museu.

O interesse pelo novo MIS, suas exposições e diversas atividades educacionais alcançaram até as regiões periféricas de São Paulo, o que gerou um grande impacto social positivo, visto que, ao tornar-se um museu convidativo, transformou hábitos e conquistou visitantes. Em pesquisa feita pela própria instituição, durante o seu ano de maior repercussão na mídia (2014), 50\% das pessoas nunca tinham ido ao MIS; 30\% não frequentavam museus (MENDES, 2014). Em comparação com pesquisas realizadas anteriormente, constataram 
ainda que, aos poucos, esse público está sendo fidelizado pelo museu, afastando o receio de que uma exposição com apelo popular não possa atrair mais do que um mero modismo (CASTILHO, 2014).

O que chama a atenção, no caso do MIS, é a maneira como esse museu conduz o seu diálogo com a sociedade por meio do lazer cultural. Se há poucos anos, os museus em geral proibiam fotografias de seu espaço e acervo, o MIS incentiva que o seu visitante registre, publique e compartilhe seus momentos no espaço, seguindo uma tendência mundial que recentemente culminou, em 2014, na criação do Selfie Day, uma ação que reúne museus do mundo todo, estimulando as pessoas a tirarem e postarem nas redes sociais uma selfie em um museu.

Não por um acaso esse é o dia de maior visitação em inúmeros museus participantes dessa campanha. E, afinal, não compete ao museu justamente dialogar com o público contemporâneo? Não se trata de uma submissão à superficialidade, mas sim de uma compreensão do perfil dessa sociedade, apresentando-se como algo próximo, possível - até divertido - para se frequentar nas horas de lazer. Não podem as selfies, ao invés de constrangerem por uma falta de respeito ao "sacro espaço" dos museus, representarem um passo importante no processo de apropriação dos museus por aqueles a quem eles de fato se destinam?: o público.

Ao se dispor como parte da Indústria Cultural na sociedade moderna, os museus, já há algumas décadas, estreitaram uma ligação com outro fenômeno social moderno, o turismo, que assim como o lazer pressupõe imensa complexidade e grande diversidade de conceitos e definições, e com efeito, contradições em relação ao seu modo de reprodução numa sociedade de consumo. O turismo, a partir do processo de globalização percorreu o mundo com o impulso advindo do avanço tecnológico dos meios de comunicação e transportes tornando-se, rapidamente, uma das principais atividades econômicas do mundo.

A relação entre lazer e turismo é bastante simbiótica, de acordo com Souza (2010), ambos são fenômenos sociais, que representam uma forma de expressão humana e se situam num tempo/espaço social, na medida em que promovem sensações de prazer, fruição e espontaneidade e promovem o contato com novas culturas. Por essa razão, no rol de segmentos elaborados, há várias tipologias de turismo, dentre eles, o chamado de Turismo Cultural (BARRETO, 2007; TOMAZZONI, 2008; SOUZA, 2010), ainda que podemos 
afirmar que, ao nosso ver, toda modalidade de turismo, independente da motivação, é uma forma de turismo cultural, uma vez que se manifesta a partir do ser humano e, de suas necessidades e experiências pessoais e do meio em que se vive.

Barreto (2007) explica que o turismo, como um fenômeno social, está intrinsecamente relacionado à cultura de forma dialógica. Para a autora, o turismo pode, ao mesmo tempo, valorizar e descaracterizar os traços culturais na relação nem sempre autêntica, o que não deve desestimular a sua prática. A autora apenas reforça a necessidade de pesquisas mais abrangentes buscando o aprimoramento da prática e as relações estabelecidas entre turismo e cultura.

Em uma perspectiva de valorização da cultura pelas práticas de turismo e de lazer cultural, conforme Tomazzoni (2008, p. 2), “o turismo e o lazer se originam e se constroem em um amplo e complexo processo de difusões e de interações culturais". Para ele, a dimensão cultural do turismo promove a valorização dos bens culturais e dos patrimônios, que se expressam no fortalecimento de identidades e manifestações no âmbito das diversas expressões culturais (costumes, tradições, hábitos, arte, arquitetura) em que a interação entre o turista e as diferentes culturas promove uma experiência bastante enriquecedora, suscitando a formação desinteressada, à qual se refere Dumazzedier.

De acordo com os argumentos de Tomazzoni (2008), as atividades de lazer e de turismo, do ponto de vista moderno, não se resumem apenas numa experiência de viagem, mas em formas de interação entre visitantes e visitados, para o autor este conceito destoa de argumentos somente econômicos nos quais normalmente o turismo está fundamentado.

Uma pesquisa de demanda turística realizada pelo Ministério do Turismo (MINTUR, 2013) mostrou que o turismo cultural é a terceira motivação para viagens internacionais ao Brasil, mesmo não sendo ele o principal foco de promoção do turismo brasileiro, muito voltado à famosa associação sol e praia.

Em outra pesquisa mais recente, o Instituto Brasileiro de Museus (IBRAM, 2016) divulgou que em 2016 os museus estavam entre os atrativos culturais mais visitados no país, o que corrobora as expectativas do Ministério do Turismo, que apresentou naquele mesmo ano dados sobre o turismo cultural no Brasil, segundo o Ministério do turismo (2017), o Brasil, no 
ano de 2016, ocupava a oitava posição em um ranking de 141 países em recursos culturais, sendo o museu um elemento em destaque do turismo cultural brasileiro.

Ao se posicionar como um espaço de lazer, o Museu corresponde a vários anseios da sociedade, ao passo que, diante do contato com o visitante, ele pode reavaliar rotineiramente suas ações educativas, todavia, sem abandonar a sua missão e identidade. Este diálogo inicial, por meio do lazer cultural, representa o ápice de uma conquista social, com a qual toda a sociedade está aprendendo a lidar, acertando e errando em sua prática.

A indústria cultural do lazer massificado alienante, seja local ou do turismo, é uma realidade à qual alguns museus pertencem, no entanto, uma outra vertente dessa indústria deve ser ressaltada. Lembramos Morin (1977), que exalta que há possibilidades para o novo, pois existem os dois lados da Indústria Cultural, a que pode criar (des)necessidades e alienar por meio do consumo obrigatório, visando exclusivamente ao lucro. Ao mesmo tempo a que pode agradar a todos, tornando o acesso ao lazer mais justo, aumentando o alcance da formação desinteressada.

Sob este aspecto, apesar do peso e do estigma que a palavra indústria carrega e da sua imediata rejeição quando associada ao termo cultura, é inegável a contribuição da indústria cultural para a democratização do acesso a espaços elitizados como ainda são considerados alguns museus.

Com todas essas abordagens do lazer aqui discutidas, reforçamos que a maioria dos visitantes, sejam eles turistas ou da população local, escolhem o museu como uma opção de lazer, especificamente, pela sua vertente da diversão, recreação e entretenimento, o que representa um grande avanço na trajetória museológica. A partir dessa escolha cabe então ao museu mediar experiências enriquecedoras que contribuam para a informação e a formação desinteressada do indivíduo. O lazer cultural pautado na experiência e não no consumo seria a porta de entrada para o conhecimento mútuo; museu-visitante/visitante-museu. Entretanto, para que isso de fato ocorra, é imprescindível que as instituições museológicas façam uso de outro valioso meio de diálogo: a Educação não formal. 


\subsubsection{Diálogos por meio da Educação Não Formal}

A Educação consiste em parte imprescindível da formação do indivíduo em toda a sua complexidade; é por meio dela que se vislumbram os caminhos da cidadania. Essa construção não acontece em formato único, somos cercados por diversas fontes de aprendizado desde que nascemos: parentes, amigos, instituições de ensino, cada qual à sua maneira, contribuindo para o desenvolvimento do indivíduo. Rememorando o célebre educador Paulo Freire, educamo-nos na interação, na relação, no convívio com o nosso meio e com os outros seres que o formam; educamo-nos, sobretudo por meio do diálogo (FREIRE, 2011).

Nesse processo de construção do cidadão, a educação possui ramificações que vão muito além da sala de aula. Nas várias maneiras em que o processo de educação pode ser estabelecido, podemos classificá-la de acordo com a instituição responsável e a sua abordagem. Assim sendo, existem: a Educação Formal, Educação Informal e a Educação Não Formal (UNESCO, 2011). Estas três esferas da educação constituem uma rede de aprendizagem, que viabiliza o aprendizado para todos os membros da sociedade, desde a infância até a velhice, de acordo com suas necessidades e interesses.

Santos e Germano (2015, p.3) apontam como "peça principal e mais básica da verdadeira arquitetura que representa a educação formal a Escola", como ferramenta de formação de indivíduos, que se apresenta e se fundamenta de forma integrada às regras sociais, organizando suas atividades de forma normatizada, através da separação dos indivíduos por faixa etária, seguindo uma rotina determinada por horários fixos para a realização das atividades. Já na educação informal, não há lugar, horários ou currículos. Os conhecimentos são partilhados em meio a uma "interação sociocultural que tem, como única condição necessária e suficiente, existir quem saiba e quem queira ou precise saber". Nela, "ensino e aprendizagem ocorrem espontaneamente" (GASPAR apud SANTOS e GERMANO, 2015, p.07), tanto que, na maioria das vezes, os próprios envolvidos não têm consciência deste processo, assim um dos principais responsáveis pela educação informal é a família.

Por fim, a educação não formal possui características como: horários pré-estabelecidos e período determinado de funcionamento, elementos que a aproximam dos preceitos da educação formal. Por outro lado, características como espontaneidade na troca mútua entre ensino e aprendizagem, espaços físicos diferentes, reunião de um público diversificado em 
vários sentidos, convergem para aquilo que se prega e se defende como sendo típico da educação informal.

Assim sendo, para Santos e Germano (2015), as atividades da educação não formal possuem características das atividades informais, porém, institucionalizadas, podendo também se apropriar de características que a aproximem do ensino formal, tal como uma normatização parcial do processo de ensino-aprendizagem. É neste campo em que, como apontado por Figurelli (2011), todas as instituições museais atuam, em uma mistura de particularidades e influências da educação formal e informal, constituindo o museu um grande expoente pela educação não formal do indivíduo.

\footnotetext{
Vistos como espaços multiculturais e interdisciplinares, como ambientes de contemplação, questionamento, descoberta, ressignificação, mediação, encantamento, entretenimento, confronto e diálogo, os museus possuem grande potencial para oferecer oportunidades educacionais a pessoas de todas as idades, formações, habilidades, grupos sociais e etnias, sendo caracterizado como um espaço de educação não-formal (FIGURELLI, 2011, p. 116).
}

As atividades educativas nos museus se caracterizam muitas vezes como eventos únicos, mas que, se forem marcantes, podem motivar interesses até então impensados e despertar sentimentos adormecidos, contribuindo para o processo de formação educativa e cultural das pessoas. Tais atividades "têm características como espontaneidade na troca mútua entre ensino e aprendizagem, espaços físicos diversificados, reunião de um público diversificado em vários sentidos" (SANTOS e GERMANO, 2015, p.08). O respeito à diversidade cultural, e a preservação do patrimônio material e imaterial (e também natural) correspondem a uma parte importante das ações educativas em relação aos bens culturais contidos em forma de acervos. Outra característica predominante é a autonomia do visitante por meio da escolha do circuito a ser percorrido e o tempo dedicado a cada espaço.

Diante da apresentação de tais conceitos é importante compreender em quais momentos a educação converge para o universo museal.

Relembrando novamente a trajetória paradigmática apresentada nos Capítulos anteriores, a educação sempre esteve associada ao Museu, especialmente, no que diz respeito ao que este se destinava (Quadro 7): ao estudo das Artes e das Ciências no Paradigma Greco-Romano e, posteriormente, ainda que de forma diferente, também no Paradigma Ciência Racional; e a 
instrução religiosa no Paradigma Judaico-Cristão. Mas essa relação educação-museu estava longe da relação educativo-museu que conhecemos hoje.

A relação educação-museu, especificamente no período Grego, era estabelecida pelo próprio frequentador (relembrando, em geral, os eruditos e filósofos), que buscava no ambiente do Mouseion apenas um local para o repouso de sua mente, libertando-o para que ele próprio determinasse o que desenvolveria no período de sua estadia, ou seja, o ambiente favorecia o estudo, mas não o incentivava e nem era responsável por ele. Já em seu período Romano, a ideia do Mouseion passa a ser associada a de um "ativo centro de pesquisa e informação cultural", como era o caso do Museu de Alexandria (CASTRO, 2009, p. 37), primando pela plena integração dos povos em torno do saber, contando com a contribuição de diversos matemáticos, médicos, historiadores, poetas, geólogos, astrônomos e filósofos vindos de diferentes partes do mundo, aproximando a instituição da característica de ser um local que favorece a educação, ainda que restrita.

A instrução religiosa do Paradigma Judaico-Cristão, exercida pelo clero, também estabelecia a relação educação-museu, no entanto, como o próprio conceito transmite, a "instrução" se aplica no sentido de que os saberes são voltados para uma determinada finalidade, neste caso, para fins exclusivamente religiosos, restringindo os instrumentos e os frequentadores. Ao se destinar novamente ao estudo das Artes e Ciências, o Museu do Paradigma Ciência Racional começa a estabelecer as bases do que viria a ser o educativo em museus como os conhecemos hoje, ainda que distantes em características. Os gabinetes de curiosidades pertencentes aos antiquários dispunham de um grau maior de informação sobre os objetos ali expostos, fruto de pesquisas de seus colecionadores (CHOAY, 2017). No entanto, tais informações estavam longe de serem utilizadas como educativas, ficando restritas aos artistas, eruditos e estudiosos. 
Quadro 7: Destaque referente ao que se destinava/ destina o Museu em cada paradigma do conhecimento

Paradigma A que o museu se destinava

Greco Romano Ao estudo das Artes e Ciências (Greco)

Judaico Cristão Instrução religiosa (Clero)

Ciência Racional Ao deleite do colecionador e ao estudo das Artes e Ciências

Atual A atender as necessidades e desejos da sociedade de acordo com a sua função social

Fonte: Elaboração própria, 2019. Adaptado dos quadros 1, 2, 3 e 4 desta pesquisa.

$\mathrm{O}$ atual paradigma iniciado no século passado, na transição das ideias de um Museu público para um Museu a serviço do público, enfim, nos apresenta a relação educativo-museu a qual de forma gradativa foi sendo desenvolvida, evoluindo para o que conhecemos hoje. Em seu início, com a criação de um número razoável de novos museus, a diversificação de tipologias e o surgimento de museus pequenos e regionais, o museu passa a ser visto como um promissor ambiente complementar à escola, mas, após os adventos da Nova Museologia, o papel de apêndice já não era suficiente, a sociedade exigia mais.

Atualmente destinado a atender as necessidades e desejos da sociedade de acordo com a sua função social, a vocação, assim como o papel social do museu contemporâneo, se ampliou, e é por meio do pertencimento coletivo que as instituições museais tornaram-se também um espaço de educação não formal.

\footnotetext{
A noção de educação nos museus tem se alargado com o passar dos anos, como um reflexo da ampliação do foco de interesse das discussões na área da Museologia, que se expandiu das coleções ao fator humano nas instituições museológicas. A concepção do museu enquanto instituição educadora, tendo ou não um setor específico encarregado da ação educativa, ganha evidência sobretudo, entre os profissionais do meio. Se no princípio via-se apenas o setor educativo como espaço destinado às ações educativas, hoje, cada vez mais os outros setores do museu são instigados a demonstrar o viés educacional em suas atividades (FIGURELLI, 2011, p. 117).
} 
Para desenvolver melhor a sua função educativa, os museus mais estruturados possuem um Programa Educativo em seu Plano Museológico ${ }^{28}$, documento que funciona como um plano diretor do museu, já que ele apresenta ações e estratégias a serem alcançadas na prática em um determinado período. É de suma importância que este Programa seja elaborado de forma integrada aos diferentes setores do museu, como identifica Figurelli (2011), qualificando assim o carácter educativo da instituição e não apenas de um determinado setor. Todavia, ainda estamos vivenciando a adoção de instrumentos na gestão museal, mas mesmo os que não possuem este documento (realidade de muitos museus), operam em seu dia a dia com várias atividades educativas.

Voltaremos nossa atenção, portanto, a duas linhas em evidência no viés educacional dos museus: visitas escolares e cursos de formação.

As visitas escolares representam parte significante do público frequentador, evidenciando a escola como um alvo constante das ações educativas dos museus. Esta relação, museu-escola, conquistou, nas últimas décadas, uma certa estabilidade: visitas agendadas, mediadores especializados em atendimento escolar e conteúdo voltado à faixa etária do grupo. Tal estabilidade leva-nos inconscientemente a associar que o educativo museal é direcionado apenas para as escolas, o que de fato ocorre em muitos casos.

Outra vertente educativa dos museus é o da formação. Desde o terceiro paradigma, o da Ciência Racional, essa vocação já era conhecida, as pesquisas aplicadas nos acervos possibilitavam uma série de estudos, o que por sua vez permitia a formação de seus colecionadores e estudiosos: antropólogos, museógrafos, arqueólogos, restringindo a formação a um grupo seleto. Nas últimas décadas, mais precisamente após os adventos da Nova Museologia, a formação aberta passou a ser uma das exigências da função social museológica, e assim alguns museus passaram a oferecer para a sociedade cursos, oficinas e palestras, ampliando suas atividades educativas, ainda que, sem grande alcance fora do círculo de seus frequentadores mais assíduos.

\footnotetext{
${ }^{28}$ O Plano Museológico é uma expressão prática da política cultural do museu, abrangendo os programas de diversas áreas: institucional, gestão de pessoas, acervos, exposições, educativo, pesquisa, arquitetônico e urbanístico, segurança, financiamento e fomento, comunicação, socioambiental, acessibilidade universal.
} 
Mas será que somente o atendimento escolar e a formação aberta serão suficientes para que o museu alcance sua função social especificamente no que tange a finalidade da educação? Neste ponto acreditamos que em um paradigma museológico futuro, que aponta para museus interativos, dinâmicos e presentes, novos diálogos por meio da educação não formal podem e devem ser abertos, permitindo o aprimoramento das ações existentes e somando novas contribuições.

Em sua maioria, a relação museu-escola se resume às visitas escolares e como o próprio nome diz, existe somente no tempo de duração da visita. A fim de que o museu cumpra a sua função educativa, no que diz respeito ao público escolar, é indispensável a interação entre a instituição museal, a escola (especialmente na figura do professor) e os alunos: antes, durante e depois da visita. O diálogo por meio da educação não formal, e não apenas o atendimento, proporcionaria as duas instituições museu-escola a ampliação de experiências, onde a visita faria parte, mas não seria o único elo entre as duas. Para que o museu, como expoente da educação não formal, deixe de ser apenas um complemento isolado às atividades escolares, faz-se necessário, então, a consonância entre o currículo escolar e o programa educativo museal, somente assim, as experiências vivenciadas poderão ser trabalhadas de forma aprofundada e não se encerrariam ao final de uma única visita.

Doravante, como grande desafio, observamos também que, muito além do público escolar, a ação educativa dos museus pode e deve alcançar a comunidade como um todo. É importante que a sociedade possa reconhecer que, além das funções de preservar, conservar, expor e pesquisar, os museus são instituições a serviço de seu desenvolvimento e procuram, por meio das ações educativas meios para expor suas práticas a sociedade. Sob este aspecto recairia na formação aberta parte desta responsabilidade. É fato que inúmeros museus oferecem cursos de formação: alguns direcionados aos profissionais da área e outros abertos à comunidade. $\mathrm{O}$ gargalo está justamente nos cursos abertos, que, com exceção dos oferecidos pelos grandes e renomados museus, invariavelmente, são vazios, ou atingem sempre o mesmo círculo de pessoas.

Muito desta condição está atrelada à reputação por ele mesmo conquistada durante anos, de ser um local de acesso e uso restrito, para que este diálogo possa enfim ser realmente estabelecido primeiramente faz-se necessária a saída dos museus de seus muros, pois, ainda que pareça antagônico, o museu precisará, de fato, imergir nos espaços de convivência da 
comunidade para que no futuro ele próprio seja um. Além da mudança de espaço, para que o museu almeje sua função social no aspecto educativo da formação, é necessário que ele amplie suas temáticas, visto que o desinteresse por parte da comunidade muitas vezes é devido à oferta de formação em temáticas extremamente técnicas ou restritas a área de Educação Patrimonial.

A diversidade de temáticas de interesses diversos é um caminho para atrair um público que não vê no museu um espaço múltiplo, e é a partir desse primeiro contato que o museu ganhará a possibilidade de conquistar um frequentador, ainda que, para isso, o museu funcione apenas como um interlocutor, já que ele próprio não terá expertise para ofertar todo e qualquer modalidade de formação.

Para Figurelli (2011), a função educativa de um museu é regulada pelas relações que estabelece com os públicos e pelos meios que utiliza para implementar estas interações. A consonância entre o currículo escolar e o programa educativo museal, e a formação diversificada em espaços de convivência da comunidade, neste caso, seriam meios para estabelecer esta interação, em outras palavras, o diálogo entre o museu e a sociedade.

Um exemplo de possibilidades dos diálogos por meio da educação não formal está nas ações da Pinacoteca de São Paulo ${ }^{29}$ que através do Núcleo de Ação Educativa (NAE), propõe iniciativas que se aproximam do diálogo aqui proposto. A iniciativa do Museu Para Todos + Educação (Figura 11), evidencia primeiramente em sua forma escrita, a importância do educativo museal democrático, um museu para todos só existe por meio da educação e a educação museal só encontra sentido em seu amplo alcance social.

As diversas cores do símbolo circular em destaque à esquerda da figura 11 sugere a diversidade de público que o educativo deseja atingir, assim como, o formato de suas ações. O círculo parecer indicar que a troca de conhecimentos entre o museu e o seu público acontecerá de forma dialógica e sem fim, e ao ser colocado propositalmente no lugar da vogal 'o', que indicaria um gênero, o museu novamente parece apontar para a tentativa da pluralidade de suas ações.

\footnotetext{
${ }^{29}$ Para informações acessar: http://museu.pinacoteca.org.br/
} 
Figura 11: Slogan do Núcleo de Ação Educativa da Pinacoteca do Estado de São Paulo

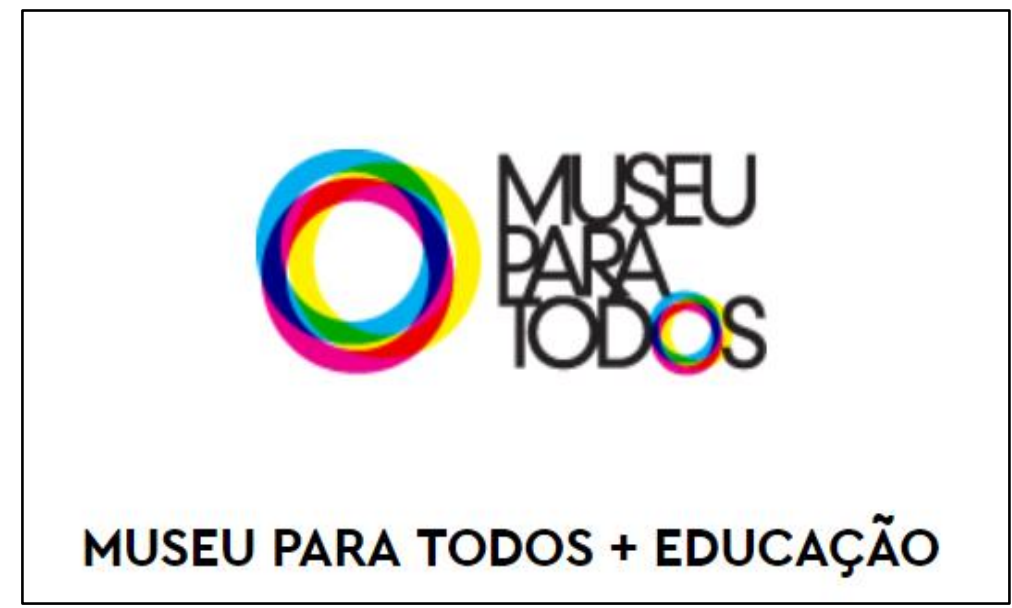

Fonte: Pinacoteca do Estado de São Paulo, 2019

O NAE desenvolve vários Programas, o de Atendimento ao Público Escolar e em Geral (Papeg), voltado aos públicos tradicionalmente recebidos pelos processos educativos, ou seja, escolares, professores e o público geral, composto pelos Programas e Projetos: Visitas Educativas, Formação para Professores, Clube dos Professores, Pina_Dentro \& Fora ${ }^{30}$, Museu para $\operatorname{Todos}^{31}$, Pinafamília, Dispositivos para Autonomia de Visita (DAV) ${ }^{32}$, Ações educativas em exposições temporárias; e os Programas Educativos Inclusivos (PEI), dedicados ao "não público", aqueles que não costumam frequentar espontaneamente a instituição, composto pelos Programas: Educativo para Públicos Especiais (PEPE) ${ }^{33}$, Programa de inclusão Sociocultural (PISC) ${ }^{34}$, Programa Meu Museu ${ }^{35}$, Programa Consciência Funcional ${ }^{36}$; Além

\footnotetext{
30 Trata-se de um material disponível para empréstimo à professores mediante uma pequena formação. Composto por quatro mochilas que tratam do eixo norteador "Identidade", é destinado à professores em atuação de ensino fundamental I, fundamental II e ensino médio.

${ }^{31}$ Trata-se de um espaço virtual alocado no site da Pinacoteca, com jogos, textos e materiais de apoio à prática pedagógica

${ }^{32}$ Os dispositivos visam incentivar a percepção, comparação, interpretação e reflexão sobre a arte, sem a participação de um educador do museu.

${ }^{33}$ Este programa que busca promover o acesso de grupos de pessoas com deficiências sensoriais, físicas, intelectuais e transtornos mentais, conta com uma série de abordagens e recursos multissensoriais: visitas educativas realizadas por educadores especializados, inclusive em Libras- Língua Brasileira de Sinais; cursos de formação para profissionais interessados em usar a arte e o patrimônio como recursos inclusivos;

e publicações para o público deficiente visual e auditivo. Para garantir a autonomia de visitação ao público com deficiência visual, foi desenvolvida a Galeria Tátil de Esculturas Brasileiras e um videoguia para o público surdo.

${ }^{34} \mathrm{O}$ objetivo deste programa é promover o acesso qualificado aos bens culturais, presentes no museu, a grupos em situação de vulnerabilidade social, com pouco ou nenhum contato com instituições oficiais de cultura. Além de mediação, curso de formação e publicações, o programa inclui a Ação Educativa Extramuros com grupos de adultos em situação de rua, por meio de oficinas de gravura e criação de texto, combinadas com visitas continuadas ao museu
} 
destes programas a Pinacoteca promove rotineiramente rodas de conversa sobre aspectos da educação museal promovidas pelo NAE, abertas ao público em geral.

Os programas, projetos e ações desenvolvidas pelo NAE da Pinacoteca de São Paulo, abrangem muito mais do que visitas escolares, permeando grande parte da complexidade que a função educativa museológica possui. Esse exemplo aponta para uma realidade não só possível como necessária. Assim como mostra o quão distante a maioria dos museus está dela.

Para que essa realidade deixe de ser virtual, além de contar com mais investimento por parte do poder público, é necessário que o museu se reeduque: organize, dinamize e qualifique a sua função educativa por meio da adoção de uma política educacional em seu Plano Museológico. É fundamental que esta política seja integrada aos seus diferentes setores, pois somente assim o museu se assumiria como uma instituição genuinamente educativa "direcionada ao ser humano e, portanto, intimamente relacionada à função social" (FIGURELLI, 2011, p. 118).

De maneira mais urgente, faz-se necessário também um caminho reverso, com a educação voltada para museus, ou seja, que ocorra desde cedo o estímulo por parte das outras instituições da educação não formal e formal, assim como dos agentes da educação informal, despertando o interesse pelo museu, nas crianças e jovens que futuramente serão seus frequentadores, questionadores e incentivadores.

O papel educativo e a relação do museu com a comunidade tornaram-se, de fato, questões nucleares do pensamento e de práticas museológicas (JULIÃO, 2006). E ao longo dos anos fomos levados a entender a relação museu e educação de forma intrínseca, uma vez que superado o estigma de que o museu era responsável apenas pela guarda e preservação dos

\footnotetext{
35 Tem como objetivo promover visitas educativas à Pinacoteca para grupos de idosos, compostos de pessoas com 60 anos ou mais. Entre suas ações está o estabelecimento de parcerias com instituições de atendimento e atenção ao idoso, bem como a promoção de cursos de formação a profissionais que trabalham com essa faixa etária.

${ }^{36}$ Dirigido à formação continuada e à integração dos funcionários da Pinacoteca, este programa é voltado prioritariamente aos profissionais do atendimento ao público (atendentes e recepcionistas), à equipe de manutenção e aos prestadores de serviço (equipes de segurança e limpeza). Organizado em vários módulos e atividades, começa por apresentar as atividades técnicas do museu e avança para discutir questões relacionadas atividades técnicas do museu e avança para discutir questões relacionadas à recepção do público, ao patrimônio e à função social do museu. Além disso, organiza visitas educativas às exposições temporárias da Pinacoteca para os funcionários, produz materiais informativos sobre elas e promove formações técnicas e experimentações plásticas.
} 
bens culturais, ele passou a ser reconhecido também pelo encargo de socializar o entendimento e o uso do acervo preservado. Mas esta relação não pode ou pelo menos não deviria acontecer sem ações planejadas, ainda que existam diversas formas de se estabelecer esta relação, é vital que cada museu em sua complexa existência encontre a que lhe sirva, maximizando a sua função educativa e ampliando assim a utilidade social do patrimônio preservado, visto que a "função educativa de uma instituição museológica ajuda a planejar e implementar a relação que o museu estabelece com a sociedade e o patrimônio" (FIGURELLI, 2011, p. 118)

A partir desta concepção, o diálogo por meio da educação não formal, muitas vezes, é a motivação do primeiro contato do indivíduo, com uma instituição museológica, ainda em sua infância, por meio das visitas escolares, ademais, com essa porta aberta, o museu passa a ter inúmeras possibilidades de exercer o seu potencial de contribuir para a formação desse indivíduo. Muito além de visitas guiadas a exposições, o educativo museal focado na construção ativa do conhecimento e no desenvolvimento do indivíduo e/ou de uma comunidade, pressupõe ações que despertem no indivíduo o consciente de seu conhecimento, instrumentalizando-o para a ação, a transformação e a superação, alcançando o que Paulo Freire apontava como uma "educação libertadora" e "por isso, respeitadora do homem como pessoa" (FREIRE, 2011, p. 53).

Diante desse enorme potencial que a educação não formal the permite, o museu estabelece também o caminho para outro diálogo, tão necessário quanto e que caracteriza uma das principais relações museológicas ao longo do tempo: o Diálogo por meio do Patrimônio Cultural.

\subsubsection{Diálogos por meio do Patrimônio Cultural}

Os dois diálogos anteriores evidenciavam em seu título a qual finalidade museal se destinavam: Diálogos por meio do Lazer Cultural, a finalidade do lazer; Diálogos por meio da Educação não formal, a finalidade da educação. Mas qual diálogo seria capaz de aprimorar a finalidade do estudo? Afinal qual seria a área de estudo do museu? 
Para responder a esta pergunta recorremos mais uma vez às inúmeras e crescentes funções que compõe a complexa função social de um museu: preservar, investigar, pesquisar, educar, inovar, coletar, conservar, interpretar, expor, transmitir, comunicar, dialogar (...). A reflexão sobre a sua área de estudo, pode ser apontada no questionamento destes verbos: o que o museu preserva, pesquisa, coleta, conserva, interpreta, expõe? Por meio de que ele educa, inova, transmite, comunica, dialoga? A resposta a todas estas perguntas é somente uma: o Patrimônio e todos os elementos a ele associados.

De acordo com Choay (2017), a ideia de patrimônio está na raiz das estruturas familiares, econômicas e jurídicas das sociedades, que, ao longo do tempo, adquiriu novos adjetivos e significados. O patrimônio pode ser individual, mas também coletivo, uma herança que representa o resultado das formas de ocupação do espaço pelo ser humano e que revela os mais diversos modos de vida que o homem estabeleceu historicamente num processo de interação com a natureza. Poulot (2013) reconhece que o significado do patrimônio sempre se reveste de novos atributos em razão do tempo histórico e conforme quem o emprega e com que finalidade o usa.

A origem do conceito de patrimônio cultural surge, primeiramente, com a ideia de patrimônio histórico e remonta ao Século XV no continente europeu, quando o poder do cristianismo exerceu forte influência na preservação dos testemunhos do Império Romano, sendo adotadas medidas para a restauração de determinados bens. Da segunda metade do século XVI até aproximadamente o segundo quartel do século XVIII surge a ideia de monumento histórico, e as antiguidades se tornaram objeto de um grande esforço para seu reconhecimento e inventário, o que incluía peças e objetos museológicos (CHOAY, 2017).

A preservação do patrimônio histórico tem sua importância revelada após a revolução francesa (CHOAY, 2017), momento em que os monumentos, obras de arte, igrejas, estatuas e referências de poder da monarquia francesa foram quase extintos pelos ideais da revolução, impondo uma nova ordem social a partir do século XVIII onde os objetos e bens materiais da igreja e da nobreza passaram a pertencer ao Estado e a serem protegidos por aparatos jurídicos que recomendavam a sua salvaguarda (CHOAY, 2017).

A partir de certo momento, já no século XX, surge um conceito mais completo de patrimônio cultural, pois compreendeu-se que os bens e artefatos eram representativos do modo de uso e ocupação do espaço e herança dos processos de apropriação da natureza, das técnicas e do 
conhecimento adquiridos ao longo do tempo pelos seres humanos, que refletia, sobretudo, nas artes e nos grandes monumentos e construções, principalmente as que remetiam ao percurso histórico europeu e ocidental.

Sobre o nosso entendimento de patrimônio cultural, utilizamos a definição do arqueólogo, historiador e museólogo francês Huges De Varine (1975), que foi diretor do Conselho Internacional de Museus (1965 - 1974), dando continuidade ao trabalho desenvolvido até então por Georges Henri Rivière, seu primeiro diretor. Segundo ele, o patrimônio cultural é uma categoria conceitual constituída de três elementos fundamentais: o primeiro representado pelos elementos naturais, pois são os recursos naturais que tornam o mundo habitável; o segundo remete ao conhecimento, as técnicas e o saber-fazer, os elementos intangíveis do patrimônio cultural; o terceiro elemento são os objetos, os artefatos, os monumentos e as demais construções humanas, que são determinados a partir da interação do ser humano com a natureza e o conhecimento adquirido.

Também compreendemos o patrimônio cultural como uma construção social, assim como esclarece o Antropólogo catalão Llorenç Prats. Em busca de uma definição, o autor expõe que o patrimônio cultural é:

\footnotetext{
Una construcción social, que aparece en los inicios de la modernidad, como una especie de religión laica, que sirve para sacralizar discursos en torno a la identidad, principalmente de carácter nacional o regional, también local, a partir de referentesreliquias que guardan una relación metonímica con la externalidad cultural percibida, en el plano del tiempo (el pasado, como tiempo fuera del tiempo, inalcanzable), de la naturaleza supuestamente indómita, incontaminada (como espacio fuera del espacio culturalmente domesticado) y del genio y la excepcionalidad (esencialmente creativa, pero no únicamente, incluso, en ocasiones, como expresión del mal, como transgresión de los límites de la condición humana culturalmente establecida) (PRATS, 2006, p. 72).
}

Faremos agora uso uma última vez dos conhecimentos adquiridos no segundo e terceiro capítulos dessa dissertação, a fim de, compreender em quais momentos e de que maneira o patrimônio cultural converge para o universo museal. Mais uma vez ressaltamos que usaremos um conceito moderno e que esta inflexão ao passado usa de uma licença poética para evidenciar os pontos de convergências dos atributos do que hoje entendemos como patrimônio cultural com as características do que no passado se compreendia como museu. 
A partir das definições apresentadas, podemos estabelecer algumas relações entre o patrimônio histórico e cultural e os museus, pois ambos são instituições e construções sociais, e este segundo, ao tempo da história, desde o mouseion, foi o responsável por guardar objetos que, apesar de tudo, eram representativos de determinado fenômeno ou sociedade/civilização, que, como afirmou Prats, guardam uma relação cultural percebida no plano do tempo. Observemos então a relação patrimônio-museu ao longo dos paradigmas do conhecimento sob a ótica do que era museu (Quadro 8).

Quadro 8: Destaque referente ao o que é museu em cada Paradigma do Conhecimento

\begin{tabular}{|c|c|c|}
\hline Paradigma & O que é museu? & \\
\hline Greco Romano & $\begin{array}{l}\text { Uma mistura de Templo e Instituição de } \\
\text { Pesquisa (Greco) }\end{array}$ & $\begin{array}{l}\text { Um conjunto grandioso de instalações } \\
\text { com diversas finalidades (Romano) }\end{array}$ \\
\hline Judaico Cristão & $\begin{array}{l}\text { Coleções particulares da Nobreza } \\
\text { (nobreza) }\end{array}$ & Coleções particulares da Igreja (Clero) \\
\hline Ciência Racional & \multicolumn{2}{|c|}{ Grandiosas Galerias Palacianas e os excêntricos Gabinetes de Curiosidades } \\
\hline Atual & Uma instituição plural em forma, conteú & finalidade e público \\
\hline
\end{tabular}

Fonte: Elaboração própria, 2019. Adaptado dos quadros 1, 2, 3 e 4 desta pesquisa.

Lembramos que os objetos presentes no mouseion, uma mistura de templo e instituição de pesquisa, tinham a conotação de oferendas, sendo de grande valor ou estima para o seu dono, eles podiam ser exibidos ao público, mas tanto os objetos doados quanto as obras de arte expostas seguiam a temática mitológica de sua época, existindo mais em função de agradar ao mito das divindades do que para serem contempladas pelo homem (CASTRO, 2009). Todavia, tanto os objetos quanto as obras ali desenvolvidas eram em grande parte representações daquela sociedade, por meio de peças ornamentadas com cenas do cotidiano.

Em sua face Romana, representada pelo "ativo centro de pesquisa e informação cultural", (CASTRO, 2009, p. 37) o mouseion de Alexandria ao destinar-se a perpetuidade e proteção da história, ciências e artes de uma dinastia, assemelha-se aos propósitos mais recentes do conceito de patrimônio, pois, ainda que, atualmente seja fortemente debatida a importância da representatividade coletiva do patrimônio, em um passado não tão longínquo e ainda 
vigente enquanto práticas de políticas públicas, a sua tendência de representatividade de apenas uma classe dominante está arraigada no conceito de patrimônio.

O conjunto grandioso de instalações com diversas finalidades de Alexandria composto por estátuas de filósofos, objetos astronômicos e cirúrgicos, exemplares exóticos, tais como, peles de animais raros, presas de elefantes, pedras e minérios trazidos de lugares distantes, além de um parque, demostram a vanguarda de Alexandria quanto a pluralidade do que lhes era considerado patrimônio. Ademais, não podemos deixar de relembrar a sua emblemática Biblioteca, cujo conteúdo registrado, organizado e pesquisado representavam o apreço pelo patrimônio ali constituído.

O museu representado pelas coleções da nobreza e da igreja do paradigma Judaico-Cristão evidencia ainda mais os interesses individuais por trás da preservação de um patrimônio, ainda que trate-se de instituições, não havia a preocupação com o interesse coletivo. Seja por espelhar grandeza e afirmação social por parte da nobreza ou por adjudicar poder e manipulação social para o clero, o patrimônio representado principalmente por objetos como pinturas, esculturas, murais, mosaicos, vitrais e tapeçarias feitos a partir de materiais preciosos, ostentavam a pujança e visavam à perpetuidade do poder de seus donos.

As salas reservadas de palácios, catedrais e mosteiros "escondiam" coleções de objetos ligados à religião: relíquias de santos, manuscritos, aparatos litúrgicos, obras de arte que exaltavam as criações divinas (como a natureza) e também inúmeros objetos 'pagãos', que naquela época confiscados pela igreja, hoje compõem os venerados acervos dos museus, principalmente europeus.

O paradigma Ciência Racional representado pelo museu enquanto grandes galerias palacianas e os excêntricos gabinetes de curiosidades, especificamente no caso deste último, preconizou a finalidade do estudo atribuída hoje ao Museu. Lembremos mais uma vez da figura dos antiquários mencionada por Choay, em que estes eruditos "por toda a Europa eles se correspondiam e se visitavam, muitas vezes trocavam objetos, informações sempre, discutindo seus achados e suas hipóteses". A autora aponta que as pesquisas de alguns eruditos antiquaries permaneciam inéditas em seus arquivos, mas eram amplamente utilizadas e citadas nas obras de outros autores, assim se constituiu um grande repertório de objetos estudados: inscrições, moedas, selos, ornatos, acessórios da vida cotidiana (pública ou privada), e os grandes edifícios religiosos (CHOAY, 2017, p. 65-66). 
Por sua vez, as grandiosas galerias palacianas, locais onde novamente o patrimônio evidencia o poder de seu dono, reis, rainhas e príncipes, renomados financiadores de expedições marítimas, das quais uma das incumbências era a de 'trazer' as curiosidades e riquezas do novo mundo, tornaram-se expoentes de uma prática arraigada nos museus: a de apropriação do patrimônio cultural, prática sob a qual o paradigma atual debruça inúmeros debates em busca de uma solução.

O paradigma atual inicia com a herança da criação de muitos museus, ainda que por motivações essencialmente políticas, o final do paradigma anterior apresentou alguns dos principais museus contemporâneos. Em 1793, o Louvre foi transformado em museu, com o objetivo de instruir a nova nação que surgia e difundir o civismo e a história, e claro, os ideais iluministas. De acordo com Carlan (2008), os cidadãos franceses teriam o conhecimento do passado e ao mesmo tempo uma legitimação ideológica dos Estados Nacionais, a partir das novas leis e aparatos jurídicos de proteção dos bens culturais franceses. No Brasil, o Museu Real (hoje, o destruído Museu Nacional, antigo palácio de D. Pedro II), foi criado pelo Rei Dom João VI, em 1818, que doou sua a primeira coleção de História Natural, inicialmente sediado no Campo de Sant'Ana, serviu para atender os interesses de promoção do progresso cultural e econômico do país (CARLAN, 2008).

Durante a análise apresentada sobre os momentos nos paradigmas anteriores em que o patrimônio cultural convergia para o universo museal, o objeto sempre esteve em destaque enquanto patrimônio. Os objetos patrimonializados logo passaram a estar disponíveis para a musealização, em sua maioria eles contavam a história ou rememoravam as conquistas de determinados povos, alcançando a categoria de patrimônio cultural (ainda que representativos das classes dominantes e fruto de pilhagem dos países colonizados), sendo o museu um lugar de guarda, proteção e pesquisa.

No paradigma atual a relação patrimônio-museu pode ser observada sob duas vertentes: a do patrimônio enquanto objeto (representativo do tangível e do intangível) e o patrimônio enquanto monumento.

Rememorando a definição proposta pelo ICOM (2001), o museu "adquire, conserva, pesquisa, comunica e expõe testemunhos materiais do homem e de seu meio" e o grande receptor dessas ações foi e ainda é o objeto. É por meio dele que o museu se apresenta e interage com o 
visitante. No entanto, apesar de todo objeto ser potencialmente um objeto museológico, nem todo objeto deveria ser um objeto museológico. "Somente se os significados atribuídos ao objeto condizerem com a missão do museu ele pode ser um objeto museológico. Ele passa a ser único, identificado em suas múltiplas possibilidades de informação, numerado com um código para identificação e controle" (MHCA, 2018).

Após a transformação do objeto em objeto museológico, ele passa por uma nova etapa:

Uma vez selecionado, interpretado, registrado, organizado e armazenado, o objeto museológico torna-se patrimônio cultural. Quando o objeto museológico identificado, passa a compor uma coleção determinada pela instituição, torna-se assim elemento de algo ainda maior: o acervo museológico (MHCA, 2018).

O acervo museológico pode ser composto por documentos: peças, objetos, artefatos ${ }^{37}$, podendo ser de cunho etnográfico, artístico, histórico, arqueológico, natural, entre outros. Cury (2014) afirma que "o objeto não vale por si só e sim por seus valores culturais", portanto, além das características tradicionalmente associadas aos objetos museológicos de raridade, antiguidade e preciosidade, eles "tem atributos e valores sociais, religiosos, estéticos, artísticos, afetivos, científicos, políticos e ideológicos” (CURY, 2014, p.51).

Zanirato (2018), afirma que, por representar regimes de ação que estabelecem sentidos sociais de pertencimento, de herança e vinculados à propriedade privada, assim como nos explicou Choay (2017), o patrimônio, quando acrescentado do adjetivo cultural, passa a se referir a um conjunto especifico de ações institucionais. Citando Ariños (2007), a autora esclarece que essas ações são aplicadas aos bens culturais e elementos que os tornam patrimonializados, considerados, portanto, acervos da sociedade.

Nos espaços culturais, especialmente nos museus, o conhecimento se constrói por meio do sujeito e do objeto. É por meio de seu acervo museológico que os museus interagem com o visitante. Um objeto, à medida que se torna um patrimônio, passa a conceber uma relação distinta e é elevado a uma outra categoria de bem cultural, aquele que é patrimonializado e ou artificado. Natalie Heinich (2013) chamou de "artificação" toda a transformação a que os testemunhos da história ou de certas culturas são submetidos, e assim, como consequência da

\footnotetext{
${ }^{37}$ Entende-se por artefato um objeto que sofreu alteração provocada pelo homem
} 
“artificação" passam a ser dotados de novos valores e significados, principalmente, aqueles que são guardados sob o teto dos museus.

A "artificação" é representada pelos objetos, artefatos e principalmente obras de arte que são musealizadas e passam a categoria de patrimônio cultural. E esse patrimônio material sempre foi o foco dos museus, o objeto durante muitos anos constituiu o centro das ações museológicas, no entanto, as decisões de o que coletar e o que expor mudaram muito ao longo das transformações do Museu, especialmente, com a chegada da Nova Museologia a partir da década de 1970.

À mesma época, surgem as preocupações internacionais, em especial, da Organização das Nações Unidas, em relação à proteção do patrimônio cultural da humanidade, com destaque à ampliação do debate em nível mundial e à deliberação de medidas para salvaguardá-lo, tendo em vista a constatação de que os mais diversos patrimônios culturais estavam ameaçados de destruição, tanto pela evolução social e econômica da própria sociedade quanto pelas inúmeras causas tradicionais de degradação (UNESCO, 1972).

No entanto, a concepção de patrimônio articulada pela UNESCO, na época, não considerou a relação integradora entre natureza e cultura, bem como a relação intrínseca com os bens imateriais, atribuindo-lhes diferentes significados, incorrendo na ideia de que o patrimônio cultural corresponderia apenas aos monumentos, às obras de arte e às demais formas de criação humana de valor universal excepcional do ponto de vista histórico, estético, etnológico ou antropológico (UNESCO, 1972).

Essa forma de compreensão, por parte da UNESCO, mudou somente a partir do reconhecimento da natureza como elemento constituinte do patrimônio cultural em $1985^{38}$, e do patrimônio imaterial em $2003^{39}$, ainda que tardiamente, o patrimônio imaterial foi acrescentado como elemento fundamental na proteção do patrimônio cultural representado pelas mais diversas manifestações intangíveis da sociedade.

A noção de patrimônio entendida para além da dimensão material dos objetos, incorpora as manifestações imateriais, o cultural e o natural. O patrimônio cultural, portanto, passa a ser

\footnotetext{
${ }^{38}$ Conferência Mundial sobre as Políticas Culturais, México, 1985. Disponível em: http://portal.iphan.gov.br/uploads/ckfinder/arquivos/Declaracao\%20do\%20Mexico\%201985.pdf

${ }^{39}$ Convenção para a salvaguarda do patrimônio cultural imaterial, Paris, 2003. Disponível em: http://portal.iphan.gov.br/uploads/ckfinder/arquivos/ConvencaoSalvaguarda.pdf
} 
também, no universo museológico, dotado de valores históricos, culturais, artísticos e simbólicos dos vários povos que compõem ou compuseram a nossa sociedade, que incluem os artefatos, objetos, obras de arte e também podem representar a memória e a identidade de um grupo social. Assim, conservar o patrimônio cultural é uma forma de "garantir o testemunho e os referenciais, não apenas de seu valor arquitetônico e histórico, mas dos valores culturais, simbólicos, de sua representatividade técnica e social" (ZANIRATO 2009 p. 138).

No universo museal o patrimônio imaterial sempre esteve presente no cotidiano dos museus, só que de maneira intrínseca, inexplorada e até ignorada. Recordamos que, oficialmente, foi somente em 2009 em um documento intitulado Código de ética do ICOM para Museus, que o Conselho acresceu à definição de 2001 e ao conceito de testemunhos a palavra imateriais, uma única palavra, mas que conferiu enorme amplitude ao objeto museológico.

A sua aceitação pela instituição é recente, trata-se de um processo ainda em construção, "a legitimidade da conservação e da valorização de um patrimônio imaterial, no todo ou em parte, baseia-se, atualmente, no interesse geral do público - e de comunidades - pela memória, por seu trabalho e suas representações" (POULOT, 2013, p.100). E é a partir do interesse de seu público que muitos museus vêm mudando a abordagem antes puramente material do próprio objeto, transformando-o em um ponto focal de apresentação também do imaterial. A noção de patrimônio passa a ser entendida para além da dimensão material de objetos e incorpora as manifestações imateriais, o cultural e o natural acompanhando, segundo van Mensch, o desenvolvimento do conceito de Cultura trabalhado pela Antropologia (CERÁVOLO, 2004, p. 330).

Além dos museus expoentes do patrimônio material adotarem abordagens do patrimônio imaterial, atualmente existem os museus que se dedicam unicamente a vertente imaterial do patrimônio, como é o caso do Museu da Pessoa ${ }^{40}$ (Brasil), um museu virtual e colaborativo aberto a toda e qualquer pessoa que queira registrar e compartilhar a sua história de vida. Sua missão ao valorizar a diversidade cultural é transformar estas histórias em fonte de conhecimento, compreensão e conexão entre pessoas e povos.

\footnotetext{
${ }^{40}$ Para mais informações acessar: http://www.museudapessoa.net/pt/home
} 
A outra vertente da relação patrimônio-museu no paradigma atual, trata-se do patrimônio enquanto monumento. Para Huges de Varine (2013), na definição clássica, o conteúdo dos museus pertence ao patrimônio cultural (nacional, regional ou local). Contudo, devemos observar que, cada vez mais, os edifícios que abrigam os museus são em grande parte prédios históricos e monumentos da arquitetura moderna, onde podemos citar, respectivamente, como exemplos o Museu da Língua Portuguesa e o Museu de arte de São Paulo Assis Chateaubriand (MASP) entre muitos outros, este último conhecido como o cartão postal da cidade de São Paulo justamente pela edificação projetada pela arquiteta Lina Bo Bardi (19141992).

Nesse sentido, Varine explica que, em razão de esses edifícios estarem a serviço do patrimônio, não são diferentes dos monumentos históricos tombados, "o que significa que o museu e tudo que ele contém pertencem ao patrimônio [...]” (VARINE, 2013, p. 173), e, portanto, devem ser submetidos às mesmas formas de uso e manutenção que lhes assegurem proteção.

Quando se trata da temática do uso do patrimônio, o museu é logo associado a um possível uso, principalmente, quando se trata da vertente do patrimônio enquanto monumento edificado. No entanto, o uso social está muito além da ocupação de um prédio. Para Zanirato

\begin{abstract}
Esses usos sociais correspondem aos modos socialmente construídos para a participação da sociedade em geral na identificação, conservação, estudo e difusão dos bens que configuram a sua identidade. Isso implica que a população se sinta identificada com os elementos a serem conservados, que se reconheça neles, para que eles se tornem, de fato, representativos dela e para ela. O reconhecimento do pertencimento coletivo dos bens acarreta esforços comuns para sua conservação e, quanto mais coletivos e representativos eles forem, mais protegidos estarão. (ZANIRATO, 2009, p.139).
\end{abstract}

Nas últimas décadas, no Brasil, assim como em todo o mundo, vivenciamos um crescente número de museus criados para fins de uso social do patrimônio edificado (em geral prédios históricos), especialmente, em casos de revitalização urbana, o que vem causando debates necessários, pois, esse uso pode sim auxiliar na revitalização de uma área, proporcionando novos e reativando antigos significados a um lugar antes abandonado, mas a rapidez com a qual o poder público muitas vezes os implementa (como ação para atender aos interesses dos agentes de produção e reprodução do espaço e não como uma verdadeira política pública), 
abrindo mão de estudos que envolvam a participação social, faz com que muitos casos assemelhem-se mais a uma ocupação e não ao uso social do patrimônio, criando museus vazios de conteúdo e de público que não os procura devido ao não pertencimento ao qual Zanirato (2009) refere-se.

Outro debate ainda em curso, diz respeito aos monumentos da arquitetura moderna que abrigam museus, também uma tendência mundial seguida pelo Brasil. Responsáveis por posicionar o museu como um atrativo turístico capaz de atrair visitantes distantes, eles despertam amor e ódio dentro e fora do universo museológico. Desde a criação do Museu Guggenheim Bilbao em 1997, projetado pelo arquiteto canadense Frank Owen Gehry, esse debate ganha adeptos de ambos os lados. É inegável o volume de visitantes que esses museus recebem, respondendo positivamente ao grande desafio imposto aos museus da atualidade: o de despertar o interesse de um público repleto de outras opções. Entretanto, também é evidente que algumas construções excessivamente espetaculares ignoram, sobrepõem-se e até opõem-se à curadoria e aos programas do museu (quando esses existem), além de, em alguns casos, ao compactuarem apenas com os interesses dos agentes de produção e reprodução do espaço, elas contribuem apenas para aumentar a gentrificação do lugar.

Com uma longa história permeada pela preservação e conservação do patrimônio material, atualmente, as instituições museológicas têm um singular comprometimento com a reflexibilidade dos olhares. Preservar e conservar deixaram de ser as principais funções de um museu para tornarem-se parte (essencialmente importante, mas agora ao lado de muitas outras) na composição da complexa função social museológica. O museu do paradigma atual, apresentado como uma instituição plural em forma, conteúdo, finalidade e público não se pretende mais o dono do patrimônio como os museus dos paradigmas anteriores, a ele lhe foi atribuída a responsabilidade de guardião; o que por sua vez também deve ser superado.

Em todo caso, o museu, segundo Varine (2013), manipula o patrimônio como forma de pedagogia ou consumo cultural, porém, deixa claro que os objetos musealizados (artificados) fazem parte de uma classe dominante (e sempre o fez). Portanto, ainda considerado um local de exaltação de objetos provenientes de apenas uma camada da sociedade, hoje, discute-se: o quão plural é de fato o acervo dos museus? Quais objetos devem ser "artificados"? Quantas pessoas realmente se reconhecem e se identificam com o patrimônio que o museu expõe? 
Neste ponto em que vivenciamos o atual paradigma, concordamos com a afirmação de Zanirato (2009), de que o contexto político social, as diretrizes jurídicas e a falta de vontade e de interesse em mudá-las apresenta uma realidade em que "a instituição museu, assim como a instituição patrimônio não consegue ser democrática, as regras institucionais não se coadunam com a experiência democrática porque pressupõem 'especialistas', critérios de 'autenticidade' e de permanência que não se adequam a sociedade em geral" (informação escrita ${ }^{41}$ ). Portanto, as respostas a esses questionamentos, certamente, não condizem com a forma com a qual o Museu do paradigma atual se apresenta: uma instituição plural em forma, conteúdo, finalidade e público, ao menos não ainda quanto à finalidade do estudo e, por consequência, do patrimônio.

Novos diálogos por meio do patrimônio cultural precisam ser abertos entre o Museu e a sociedade para que a finalidade do estudo seja atendida, não em partes, não com interesses, mas em concordância com a função social museológica. A democratização dos bens patrimoniais envolve inúmeros aspectos, entre eles, Fonseca (2005) aponta uma maior participação da sociedade na produção desses bens; a garantia da preservação da memória dos mais diversos grupos sociais e não somente das elites; o respeito à autonomia das práticas populares; o direito de acesso aos bens culturais; entre outros. Apesar de distantes do atual mecanismo de patrimonialização, para a autora, as formas e as condições de recepção do patrimônio por parte dos mais diferentes grupos sociais são essenciais, é por meio desse processo que a maneira como o indivíduo vê e resignifica os bens patrimoniais irá lhe despertar o sentido da preservação e contribuir para isso.

Como parte desse mecanismo, o Museu parece já ter encontrado um caminho para a mudança: os ecomuseus.

Não se trata de um conceito novo, Scheiner (2012) relata que o termo específico ecomuseus criado por Hughes De Varine passou a ser conhecido durante a $9^{a}$ Conferência Geral do ICOM, realizada em Grenoble, em 1971, em um momento em que emerge a ideia de um "patrimônio" ligado a uma comunidade e a um meio ambiente. Companheiro e entusiasta das

\footnotetext{
${ }^{41}$ Informação obtida na correção da professora Silvia Helena Zanirato durante banca de qualificação desta pesquisa em 07/06/2017.
} 
ideias de Georges-Henri Rivière, Varine acreditava na vitalidade e na utilidade dos museus para a sociedade, mas devido ao peso quase que letárgico que o termo museu carregava na época, Varine e Rivière viram-se obrigados a criar um novo termo que simbolizasse um museu mais ativo e consciente de suas funções de dentro e de fora de suas paredes. Recusando-se a abandonar completamente o termo que acompanhara a instituição desde o seu nascimento Varine relata: "eu tentei diferentes combinações de sílabas envolvendo as duas palavras, 'ecologia' e 'museu'. Na segunda ou terceira tentativa, eu cheguei a 'ecomuseu'." O novo termo ganharia notoriedade graças a um discurso de Robert Poujade, então Ministro do Meio Ambiente e proteção da natureza da França "O Ministro Poujade usou pela primeira vez o termo 'ecomuseu' alguns meses depois, em Dijon, em 3 de setembro de 1971, num discurso para 500 museólogos e museógrafos de todo o mundo" (VARINE, p. 48, 1992 apud SCHEINER, p. 19, 2012).

Tanto o novo termo quanto os seus significados tiveram as suas matrizes nos museus a céu aberto, museus ateliers e parques naturais musealizados, por isso, a necessidade de associação do termo ecologia. Mas, com o passar do tempo, o termo foi ganhando amplitude, obedecendo ao que Rivière assertivamente designou como um termo com uma definição evolutiva. Essa evolução deve-se ao alcance que os ecomuseus ganharam. De acordo com Poulot:

\begin{abstract}
Os ecomuseus pretendem ser, então, o espelho em que uma população se olha para se reconhecer nesse espaço, no qual ela procura a explicação do território a que está vinculada, conectada com [a história] das populações precedentes. Um espelho que essa população apresenta a seus hóspedes para que seja mais bem compreendida, no respeito por seu trabalho, por seus comportamentos e por sua intimidade. (POULOT, 2013, p.56)
\end{abstract}

Vejamos o grande salto que os ecomuseus representam. O reconhecimento dito por Poulot (2013) passa a ser peça fundamental do pertencimento, o que dialoga diretamente com o conceito de usos sociais do patrimônio apresentado por Zanirato (2009), e é por meio desse pertencimento que a população se vê incentivada a convidar os visitantes, em outras palavras, e rememorando a trajetória paradigmática dos museus: a população antes tratada como público, cujo acesso era restrito, passou vagarosamente a ser aceita, para então, após muitas mudanças dentro e fora do universo museológico, ser convidada, mas agora, nesse novo modelo, essa mesma população torna-se a anfitriã. 
A partir desta abordagem de como museu enxerga a população, fica evidente as inúmeras distinções que o ecomuseu apresenta frente ao museu tradicional, mas deixemos claro que não se trata de uma dicotomia “ambos são representações do fenômeno Museu, adequadas à época em que emergiram como modelos de prática museológica (respectivamente, séculos XVIIXVIII e segunda metade do século XX)” (SCHEINER, 2012, p. 25). Os que insistem em considerar essa oposição estão, na verdade, confundindo o potencial (do modelo) com a maneira como esse potencial se realiza na prática.

Não é por um acaso que os ecomuseus surgem à mesma época que o movimento pela Nova Museologia, ao contrário, eles não somente são frutos dela, como também representam a concretização de muitos dos seus princípios e práticas.

Atendendo à característica de definição evolutiva, antevista por seus criadores, o conceito assim como a prática do ecomuseu extrapolou o território francês (onde tanto o conceito quanto a sua aplicação tiveram início) e incorporou mais significados: essas rotas, que orientam a implementação de processos patrimoniais por intermédio de novos paradigmas, entendem que o museu deve ir ao encontro da comunidade (ao invés de esperar a visita do público) e atuar em relação à musealização de um território (e não ficar restrito a um edifício). "A autogestão, ou gestão comunitária, são outros aspectos que têm consolidado essas novas propostas" (BRUNO, 2008, p. 6). A sua lógica comunitária passou a ser definida pela territorialidade do campo de intervenção e pela participação da população "que pode passar do papel de consumidor do museu para a função de ator, para não dizer de autor do museu" (POULOT, 2013, p.56).

Faremos então um pequeno esclarecimento sobre a aplicação dos termos ecomuseu e museu comunitário. Ao longo de sua carreira Huges de Varine confirmou a circunstancialidade da criação do termo ecomuseu, chegando ele próprio a solicitar que as experiências que assim se reconhecem sejam nomeadas 'museus comunitários'. Entretanto, segundo Scheiner (2012), é certo que o termo 'ecomuseu' passou a ser sinônimo de uma tipologia muito especial de museu comunitário, fundamentado na musealização de um território e na relação entre este território, o meio ambiente integral (entendido como patrimônio) e as comunidades que ali conviveram ou convivem. 
Os ecomuseus vigoram no atual paradigma, não sabemos exatamente quantos existem ao redor do mundo, a realidade é que eles passaram por momentos de incertezas mas ainda prosperam e continuam a serem criados, ao passo que, isso não representa o fim dos museus tradicionais; ambos coexistem. No entanto, os princípios do ecomuseu, cujo diálogo feito para e pela sociedade o aproxima mais da atualidade, vagarosamente percorrem de maneira positiva os museus tradicionais que, pouco a pouco, absorvem algumas mudanças, sendo a principal delas referente à abordagem do patrimônio cultural. Um exemplo disso está na ampliação da própria noção de objeto museológico, que passa a incluir objetos mais quotidianos, cuja manipulação pode, inclusive, ser incentivada.

Muito além de um conceito, ao apresentar os membros de uma comunidade como atores do processo de formulação, execução e manutenção de um museu (sendo ou podendo ser em algum momento acompanhados por um museólogo), o ecomuseu, fruto de uma Nova Museologia, representa o ápice da complexa função social museológica: a instrumentalização do indivíduo a qual Paulo Freire tanto sonhava.

Diferente dos diálogos anteriores, não apresentaremos um ecomuseu como exemplo das potencialidades do diálogo por meio do patrimônio cultural. Acreditamos que o conceito de ecomuseu pressupõe a experimentação e uma identidade própria, não há um modelo. Ademais, devido às características determinantes desse conceito, seria utópico pensar que todo museu possa sê-lo. Sua importância está justamente em contribuir para as mudanças, tornando-se uma espécie de piloto, como foi o caso da incorporação do patrimônio imaterial por parte dos museus. Se hoje somos presenteados com museus que abordam os saberes e fazeres, principalmente, de uma classe social que, há poucas décadas, era ignorada como público, devemos isso aos ecomuseus que colocaram os saberes e os fazeres populares no seu devido patamar museológico.

$\mathrm{Na}$ impossibilidade do modelo museu adaptar-se completamente ao modelo ecomuseu, recordamos e apontamos a possibilidade da ideia de integralidade, que não se trata de um tipo de museu, mas sim da capacidade intrínseca que possui qualquer representação do fenômeno Museu de "estabelecer relações com o espaço, o tempo e a memória - e de atuar diretamente junto a determinados grupos sociais" (SCHEINER, p. 19, 2012). Reconhecendo a importância das dimensões sociais e políticas do museu, defendemos assim como Varine (1975) a promoção de um "museu integral". 
Diante da possibilidade da integralidade, vislumbramos a transversalidade dos três diálogos aqui propostos: o diálogo por meio do lazer cultural, estabelecido tanto para fins de entretenimento quanto para o desenvolvimento do próprio individuo, distanciar-se-ia do lazer alienante, ao integrar, em suas ações, o diálogo por meio da educação não formal. Este então, ao ser proposto tanto para fins de formação, quanto para a disseminação do próprio saber, estreitar-se-ia seus laços com a sociedade ao integrar o diálogo por meio do patrimônio cultural, que, por sua vez, ao integrar-se aos dois diálogos anteriores, atenderia tanto a sua finalidade do estudo quanto no aprimoramento da ainda sonhada democratização do patrimônio.

Esse diálogo transversal proposto em um Museu Integral, além de atender as três finalidades museológicas: lazer, educação e estudo, aproximaria o museu de sua função social, a qual, em um desafiador paradigma museológico futuro que aponta para museus interativos, dinâmicos e presentes, encontra a sua existência associada ao pertencimento do indivíduo.

Assim, levantamos um último questionamento que conduzirá à reflexão nas considerações finais:

Será que o museu quer pertencer a todos? 


\section{CONSIDERAÇÕES FINAIS}

Proporcionar uma visão tão panorâmica quanto possível das transformações da instituição Museu apresentando a sua trajetória a partir das mudanças dos paradigmas do conhecimento da sociedade constituiu o objetivo principal desta pesquisa. $\mathrm{O}$ intuito e a ambição foram poder contribuir para a compreensão do museu contemporâneo. Procuramos demonstrar como a partir da Nova Museologia enquanto movimento de larga abrangência teórica e metodológica pertencente ao paradigma atual, os museus repensaram a sua função social. Fruto de sua longa trajetória, a complexa função social museal é uma realidade e ao mesmo tempo um desafio, cujo aprimoramento de seu alcance dependerá da capacidade de o museu dialogar com a sociedade em um paradigma futuro.

Iniciamos esta pesquisa, ainda na introdução, impulsionando a reflexão sobre a definição de um conceito central: o que é um museu? Apresentamos três pontos de vista: administrativo, profissional e acadêmico. Ao ampliar nossos horizontes sobre esse conceito, questionamos se um Zoológico e um Jardim Botânico desempenham as funções de um museu - a resposta veio por meio do Processo Curatorial de Ulpiano Bezerra de Menezes, que de forma libertadora e reflexiva nos empoderou para tomar tal decisão.

Instrumentalizados pelo processo curatorial de Ulpiano, iniciamos nossa empreitada paradigmática com o Capítulo 2, Paradigmas Museológicos, recorrendo a fontes como Thomas Kuhn (1970), Boaventura de Souza Santos (2006) e Jessé Souza (2017) para elucidar o que são os paradigmas do conhecimento.

Lembramos a nossa citação em Souza (2017, p. 14, grifo nosso) que dizia que "um 'Paradigma' é o horizonte histórico que define os pressupostos para qualquer tipo de conhecimento", complementando que, "normalmente, todas as pessoas são influenciadas pelo paradigma na qual são criadas e ninguém, em condições normais, pensa além de seu tempo". O que nos faz pensar o quanto devemos ser gratos aos "anormais" de nossa história, foram eles, os corajosos responsáveis por inúmeros avanços em nossa trajetória humana, são eles, os "anormais" que pensaram além de seu tempo, e mesmo alguns deles pagando com a própria vida, nos presentearam com o desenvolvimento humano. Por isso, não podíamos deixar de dedicar nosso simbólico agradecimento aos "anormais" Platão (428/427-348/347 
a.C.), Aristóteles (384 a.C.-322 a.C.), Nicolau Copérnico (1473-1543), Leonardo Da Vinci (1452-1519), Galileu Galilei (1564-1642), René Descartes (1596-1650), Isaac Newton (16431727), Mary Wollenstonecraft (1759-1797), Charles Darwin (1809-1882), Karl Marx (18181883), Sigmund Freud (1856-1939), Nikola Tesla (1856-1943), Marie Curie (1867-1934), Mahatma Ganghi (1869-1948), Albert Einstein (1879-1955), Alan Turing (1912-1954), Martin Luther King Jr (1929-1968) e a todos aqueles que a história e a memória não nos permitiu lembrar seu nome, mas cujo caminho aberto possibilitou ainda que indiretamente esta dissertação.

Estabelecendo os paradigmas como modelos de produção do conhecimento durante um determinado período, apresentamos as quatro formas diferentes de compreensão do mundo conhecidas pelo ocidente: Paradigma Greco-Romano, Paradigma Judaico-Cristão, Paradigma Ciência Racional e o Paradigma Atual.

Entendemos que a cada mudança de paradigma do conhecimento da sociedade, o Museu também sofreu uma mudança paradigmática. Por isso em uma análise paralela, mas, ao mesmo tempo, complementar da trajetória da instituição Museu e das mudanças de paradigmas do conhecimento, buscamos as contribuições de todos os paradigmas para a construção da instituição museu como a conhecemos hoje. Para tanto, usamos como fio condutor recorrente a apresentação e análise de todos os paradigmas, as respostas aos questionamentos: O que é conhecimento? O que é museu? A que se destina? A quem se destina?

A partir da pesquisa bibliográfica prevista em nossos procedimentos metodológicos, recorremos às autoras Ana Lúcia Siaines de Castro (2009), Marlene Suano (1986) e Françoise Choay (2017), para exibir em quadros de forma consolidada as respostas previamente apresentadas e analisadas, permitindo ao leitor uma visão mais clara das principais características do universo museal em cada paradigma do conhecimento, assim exibimos os quadros 1,2 e 3 .

Desta maneira a ida ao passado no Capítulo 2 Paradigmas Museológicos possibilitou o cumprimento da primeira parte de nosso objetivo principal: analisar as transformações da instituição Museu apresentando a sua trajetória a partir das mudanças dos paradigmas de conhecimento da sociedade. 
As reflexões históricas propostas no segundo capítulo ensejaram o ingresso nos aspectos determinantes das problemáticas museológicas contemporâneas, entretanto destacamos que os paradigmas não são caixas que encerram um determinado assunto, ao contrário, são vetores que desencadeiam debates e fundamentam análises. Deste modo, o Capítulo 3, Um paradigma em construção, uma nova realidade museológica exibiu o Paradigma Atual, ainda sem um nome firmado, mas que mostra desde seu início a sua face questionadora. Relembramos, que é sob a luz deste novo paradigma que se inserem as contribuições dessa pesquisa, fruto das características do paradigma vigente, também repleta de questionamentos e incertezas e, que mesmo após a sua concretização se propõe aberta a colaborações.

Iniciamos o terceiro capítulo contando com a autora Alice Duarte (2013) para apresentar o contexto histórico/social do ano de 1968, que ficaria conhecido, principalmente na Europa, como o ano da "Revolução Cultural". Este contexto de intensa indagação e mudança que abarcou a década de 1960 não permitiu que o museu passasse ileso. Nas duas décadas seguintes o questionamento ao papel dos museus na sociedade intensificou-se, o que nos levou a retratar quais foram as respostas do universo museal.

Buscando o contexto destas respostas, evidenciamos o momento em que o Museu começa a transpor a barreira de instituição meramente pública, para uma instituição a serviço do desenvolvimento da sociedade, percorremos de forma cronológica os momentos e os documentos que firmaram a Museologia enquanto campo científico, evento este, grande responsável pela mudança de posicionamento dos museus no Paradigma Atual.

Pontuamos e analisamos alguns dos encontros científicos e acadêmicos mediados pelo ICOM e pelo ICOFOM. Usando como ponto de partida a criação do ICOFOM em 1976 e sob as referências de Maria Cristina Oliveira Bruno (2006), Suely Moraes Cerávolo (2004) e principalmente a partir das contribuições de Marília Xavier Cury (2014), percorremos as décadas de 1970, 1980, 1990.

Destacamos que em seus primeiros encontros a preocupação do Comitê concentrou-se na delimitação conceitual do campo da Museologia na busca de consolidá-la como ciência. Superado este desafio, o que vimos nos anos seguintes, foram diferentes abordagens para a criação de uma Teoria Museológica, para então, na década de 1990, após consolidada como 
ciência, a Museologia passasse a abordar problemáticas do âmbito mais prático e crítico de seu objeto de estudo.

Durante a apresentação cronológica dos encontros organizados pelo ICOFOM, introduzimos três publicações: MuWop, ISS, e a Museum International. Cada qual a sua maneira contribuiu e ainda contribui para o fortalecimento e o aperfeiçoamento da teoria e das práticas museais, valendo então o destaque feito ao interpretar algumas de suas capas.

Tendo como base o que é Museologia e a sua abrangência, revelamos, então, o que incitou a efetiva renovação de todos os museus do século XXI: A Nova Museologia.

Enfatizamos que não há nada de errado com a Museologia praticada até o início dos anos 1960/1970, suas contribuições permanecem em uso, tanto que para Cury (2014), a "nova" não contrasta com a "antiga", ela amplia o modelo metodológico de interação entre o patrimônio cultural e a sociedade. No entanto, com um olhar crítico, fica perceptível que a antiga tratava excessivamente sobre os métodos e abrangia de forma escassa as finalidades do museu, ou seja, negligenciava as razões para a sua existência, bem como a sua vocação social.

Com inúmeras problemáticas que permitiram e incentivaram a chegada de uma Nova Museologia, desta vez, exploramos três momentos e seus respectivos documentos: a Mesa Redonda de Santiago do Chile (1972) por colocar o museu como um espaço privilegiado de educação não formal, especialmente na formação cultural do indivíduo, evocando a função social museológica; as Declarações de Quebec e de Oaxaca (1984), que sistematizaram os princípios fundamentais da Nova Museologia, ampliando o objeto de estudo da Museologia e consequentemente da práxis museal, da relação Homem - Objeto - Cenário para a relação Homem/Sociedade - Objeto/Patrimônio - Cenário/Território; e por fim, a Declaração de Caracas (1992) por apresentar as reformulações das políticas de formação e conservação de acervos, de pesquisa, de educação e comunicação, em consonância com a recente aprimorada função social dos museus.

Neste momento de considerações finais, lembramos uma triste ausência ao emblemático evento de Santigo do Chile. Convidado para presidir o evento pelo amigo Huges de Varine, então presidente do ICOM, Paulo Freire, o educador e, patrono da educação brasileira (pelo menos até o presente e turbulento momento político do Brasil que tenta destituí-lo, negando seu legado) não pôde comparecer. A recusa não foi de Paulo Freire, mas sim da Ditadura 
Brasileira que não autorizou a convocação a ele feita pela UNESCO - deixando ainda a dúvida tanto no passado quanto no presente - quais seriam os "perigos" de ouvir Paulo Freire?

Imaginemos somente por um instante como seria hoje o universo museal se fosse permitido a Paulo Freire a oportunidade de transpor suas ideias de educador para as experiências museológicas?

Sua ausência apesar de sentida não vetou totalmente a presença de suas ideias e isso fica evidente no documento final elaborado pela UNESCO. Apesar de não ter declaradamente tal intenção e não ter escrito nada especificamente sobre museus e patrimônio, "o pensamento de Paulo Freire foi muito importante na Museologia a partir dos anos 1970, sobretudo, no que se refere ao conceito "conscientização" da transformação do homem-objeto em homem-sujeito" (ALVES e REIS, 2013, p. 122). A influência de Paulo Freire nos princípios e práticas da Nova Museologia, assim como a sua "presença oculta" na Mesa Redonda de Santiago pode ser encontrada em inúmeros outros momentos, documentos e práticas da Nova Museologia, cabendo aqui apontar esta temática ainda pouquíssimo explorada como um caminho para futuros estudos acadêmicos.

Após tantos acontecimentos, fóruns, declarações e publicações, deixamos evidente que a Nova Museologia não se trata de um movimento transitório. Muito além de conceitos, sua verdadeira contribuição foi a de pensar um museu de forma diferente, "a expressão 'Nova Museologia' remete para um conjunto muito alargado de questões e problemáticas que permanecem centrais para a ambicionada renovação museológica contemporânea" (DUARTE, 2013, p. 115).

Apresentados ao movimento responsável por enfatizar e extravasar a dimensão social dos museus, enfim, conhecemos a sua mais valiosa contribuição: o debate da função social museológica.

Esclarecemos que a função social dos museus não se trata de uma única função, ao contrário, trata-se de um conceito e que por sua natureza agregadora jamais poderá ser delimitado. Ainda assim, expusemos algumas funções que a compõem, para que o seu entendimento ficasse menos abstrato ao leitor, apontamos, por exemplo: investigar, questionar, denunciar, inovar, preservar, colecionar, coletar, estudar, interpretar, pesquisar, educar, transmitir, 
debater, dialogar, conscientizar, valorizar, incentivar, entreter, democratizar [...] mas ressaltamos que a união destas e de muitas outras funções inerentes ao Museu e ao imaginário das pessoas sobre o que é um museu é o que de fato compõe a sua função social.

Nas palavras do historiador francês Dominique Poulot (2013), este caminho nunca mais foi desmentido, no entanto, o estabelecimento dos princípios da Nova Museologia que clamavam por uma função social plural, abrangente e democrática ainda "esbarram" na realidade dos museus que, com exceção de alguns casos renomados, com poucos investimentos, quadro de funcionários reduzidos e infraestrutura precária, não conseguem atender com qualidade a sua função social. Assim, recorremos novamente às autoras Alice Duarte (2013), Maria Cristina Oliveira Bruno (2006) e Marília Xavier Cury (2014b), para demonstrar os aceites e recusas, transformações e adaptações do museu contemporâneo pós-movimento da Nova Museologia e a consequente convocação pela função social museológica.

E foi por meio de Marília Xavier Cury (2014b) que conhecemos as ideias de Lauro Zavala (2003), de que as transformações ocorridas nas ciências sociais nos últimos 40 anos, provocadas essencialmente pela transdisciplinaridade, afetaram diretamente os museus, criando, no momento atual, o que o autor intitula de dois paradigmas (museais): o tradicional (alicerçado na "antiga” Museologia) e o emergente (alicerçado na "nova” museologia).

Esperamos ter esclarecido que diferente dos paradigmas antecessores, o museu do Paradigma Atual não se apresenta com uma identidade uniforme, ele vive a experimentação do Museu Tradicional com o Museu Emergente, o qual Cury (2014b) denominou de Museu em Transição, e foi a partir da análise das características deste último que encerramos o terceiro capítulo retomando nossa tarefa de apresentar o quadro com as respostas consolidadas de nossos questionamentos ( $\mathrm{O}$ que é conhecimento? O que é museu? A que se destina? A quem se destina?), condutores referente às principais características do $4^{\circ}$ paradigma, só que desta vez, também apresentamos o Quadro 5, que cruza com as informações das características do Museu contemporâneo do Quadro 4, o intitulado Museu em Transição apresentado por Cury (2014b), fundamentando assim as respostas obtidas.

Apontamos em uma análise final deste que foi o terceiro capítulo, que o Museu enquanto instituição do paradigma vigente é passível de falhas e apresenta-se de formas provisórias, buscando na interdisciplinaridade soluções para problemas históricos. Vivendo em 
experimentação, ele é contraditório em sua essência. O que impõe ao futuro dos museus um grande desafio no que diz respeito à sua função social.

Assim, nosso mergulho no presente durante o Capítulo 3 Um paradigma em construção, uma nova realidade museológica, possibilitou o cumprimento da segunda parte de nosso objetivo principal: apresentar o museu contemporâneo a partir da concepção proposta pela Nova Museologia sobre a função social dos museus. Mas longe da pretensão de encerrar o debate a respeito da função social museológica, este Capítulo que trata de um paradigma, de uma realidade museológica ainda em construção terminou elencando algumas dúvidas sobre o futuro dos museus: como construir as mensagens museológicas agindo dialogicamente? Quais seriam as melhores metodologias para as equipes se adequarem para atuar na dimensão dialógica? Como disseminar essa nova concepção de maneira a mudar as mentalidades vigentes? Como inserir o público nos processos museológicos? Como inserir a fala do público na construção do museu? Como tornar a fala do visitante constitutiva da instituição?

Sem respostas, vislumbramos um caminho e assim chegamos, então, ao quarto e último Capítulo. As análises feitas do passado, no Capítulo 2, e do presente, no Capítulo 3, nos permitiram que, no Capítulo 4 Paradigmas Museológicos Futuros: museus interativos, dinâmicos e presentes, delineássemos a perspectiva de três novas formas de diálogos do museu com a sociedade, diálogos estes que, conforme justificamos, favoreceriam no alcance das três finalidades primas do museu: estudo, educação e lazer, e, consequentemente, por meio do aprimoramento da função social dos museus, culminariam no desenvolvimento da sociedade.

Iniciamos o Capítulo final questionando a validade de nossa proposta: se o paradigma do conhecimento atual ainda não terminou, como e por que pensar em um paradigma futuro? A resposta para esta pergunta ainda está em progresso, independente do reconhecimento de estarmos ou não vivendo em um novo paradigma do conhecimento, diante das visíveis mudanças em nosso meio, lembramos que é de suma importância que o Museu busque entender e se antecipe ao que provavelmente continuará e ao que poderá plausivelmente mudar em sua própria trajetória, principalmente por que o futuro aponta que o museu estático está fadado a desaparecer, dando lugar a um museu interativo, dinâmico e presente, de acordo com o novo perfil da instituição demandada pela sua função social. 
Mesmo tendo em vista a idéia de que não existe uma fórmula que leve o museu à perfeição em sua atuação, dada a sua complexidade, apontamos que, quanto mais o Museu ampliar seus horizontes e aprimorar as suas formas de diálogo com a sociedade, mais o caminho da mudança será engrandecedor para todos. Assim, no panorama de diversidade de museus e de públicos que a trajetória paradigmática dos museus proporcionou ao paradigma atual, suscitamos as dúvidas apresentadas no final do Capítulo 3: como estabelecer um diálogo?

Sob a premissa de que novos diálogos precisam ser abertos, para que novas práticas sejam encontradas e, principalmente, para que as finalidades pretendidas pelo museu e apontadas na definição do ICOM: Estudo, Educação e Lazer sejam alcançadas, esclarecemos e reforçamos mais uma vez que, apesar do adjetivo novas, não se trata de algo que não exista, as ideias são retomadas, reformuladas ou eram faladas, porém não ouvidas. Elas apresentam-se novas quando inseridas em um novo contexto.

Partindo deste princípio, antes de delinear quais seriam as novas formas de diálogo entre o museu e a sociedade, recorremos a Teresa Cristina Scheiner (2012) e oportunamente abordamos o conceito de Museu Integral, cuja matriz teórica contribuiu e ainda tem muito a contribuir para o surgimento de novos diálogos e consequentemente de novas práticas museais.

Não se tratando de um tipo de museu, mas sim do próprio existir do museu em sua capacidade intrínseca de estabelecer relações com o espaço, o tempo e a memória - e de atuar diretamente junto a determinados grupos sociais. Demonstramos que o conceito de integralidade conectase ainda com a proposta do novo lugar metodológico da Museologia, Sociedade-PatrimônioTerritório, apresentada por Cury (2014) e pretendida nas Declarações de Quebec e de Oaxaca (1984), aproximando a Museologia da práxis museal.

Retomando o questionamento proposto sobre como estabelecer um diálogo em um novo panorama de diversidade de museus e de públicos. Lembramos que estamos falando de um espaço (museu) de construção/disseminação do conhecimento. E a produção deste conhecimento não cabe mais ser feita para o "consumo" passivo do visitante. Ele quer, pode e deve participar de maneira ativa tanto da sua construção quanto da sua disseminação. E isso só ocorrerá por meio do diálogo, e não qualquer diálogo. 
Por isso evocamos novamente Paulo Freire (2011), agora em seu campo acadêmico mais conhecido, o da Pedagogia Histórico Crítica para defender que só o diálogo comunica e gera conhecimento. A ligação do museu com a sociedade geraria a criticidade. E esta por sua vez potencializaria o desenvolvimento recíproco, tudo por meio do diálogo.

Assim, partimos para a nossa contribuição final, delinear a perspectiva de três novas formas de diálogos do museu com a sociedade, diálogos estes, que a nosso ver, fazendo uso da criticidade e do desenvolvimento recíproco, favoreceriam no alcance das três finalidades prima do museu (estudo, educação e lazer) e consequentemente através do aprimoramento de sua função social, culminariam no desenvolvimento da sociedade. Apresentamos então, na sequência os itens: Diálogos por meio do Lazer Cultural, Diálogos por meio da Educação Não Formal e Diálogos por meio do Patrimônio Cultural.

Contamos com as contribuições feitas por vários autores, dos quais destacamos no item 4.1.1 Diálogos por meio do Lazer Cultural, Jofre Dumazedier (1973) na definição conceitual de Lazer, Max Horkheimer e Theodor W. Adorno (1997) nos apontamentos sobre Indústria Cultural, Madalena Aulicino (2011) na discussão do lazer como instrumento de inserção e distinção social e Edegar Luis Tomazzoni (2008) nas observações a respeito da relação entre Lazer Cultural e Turismo, especialmente para pontuar o lugar dos museus nesta relação.

No Item 4.1.2 Diálogos por meio da Educação Não Formal, destacamos Thiago da Silva Santos e Marcelo Gomes Germano (2015) na definição conceitual de educação não formal e Gabriela Ramos Figurelli (2011) na articulação entre educação e museus. E no item 4.1.3 Diálogos por meio do Patrimônio Cultural, destacamos Françoise Choay (2017) na definição conceitual de patrimônio cultural, Huges de Varine (2013) nas observações sobre a relação museus e patrimônio e Silvia Helena Zanirato (2009) nos apontamentos a respeito dos usos sociais do patrimônio.

Outra fonte que utilizamos foram os quadros 1, 2, 3 e 4 desenvolvidos por esta pesquisa durante os Capítulos 2 e 3. A sua retomada permitiu que vislumbrássemos as relações lazermuseu, educação-museu e patrimônio-museu em meio a trajetória paradigmática museológica, uma retomada necessária para contextuar a construção dessas relações e assim evidenciar suas potencialidades no alcance das finalidades prima do Museu contemporâneo (estudo, educação e lazer). 
Em cada diálogo proposto, a exemplo dos Capítulos anteriores, adotamos fios condutores, mas desta vez os questionamentos foram: Do que se tratam os conceitos (Lazer Cultural, Educação Não Formal e Patrimônio Cultural); Em que momento durante os paradigmas do conhecimento (passados) eles convergiram para o universo museal; Como eles são entendidos nos museus do paradigma atual; e por fim, como esta relação pode ser estabelecida em um futuro, a fim de aprimorar o alcance da função social do Museu.

Neste momento final, não recuperaremos pontualmente cada um dos diálogos. Aproveitaremos para usar as contribuições feitas por eles para responder a questão propositalmente deixada em aberto no final do Capítulo 4: O museu quer pertencer a todos?

Um museu que não pertence a todos, pertence a alguém que o monopoliza. E foi assim desde o início, nossa trajetória paradigmática apresentou o museu que pertenceu aos eruditos gregos e romanos no Paradigma Greco-Romano, que pertenceu a classe dominante da nobreza e do clero no Paradigma Judaico-Cristão e que pertenceu aos colecionadores e eruditos, reis e rainhas do Paradigma Ciência Racional.

Acreditamos que no Paradigma Atual as regras institucionais (visto que as instituições são criações da sociedade e que presumem um punhado de regras para a sua existência) que cercam o seu funcionamento, "guardam" o seu acervo e "protegem" o seu patrimônio, antagonizam e até impossibilitam a sua experiência democrática. Entretanto, Duarte (2013) lembra-nos de que precisamos fazer uso da apreciação crítica de que, em sua trajetória, "o museu foi um instrumento ao serviço das elites sociais e intelectuais", que tinham acesso a tudo que lhe era contido. Para a autora "é entendido que a continuação da sua existência deve passar pela sua transformação em instituição ao serviço de todos e utilizada por todos" (DUARTE, 2013, p. 101). O que nos leva a pensar: essas regras institucionais "guardam" o seu acervo de quem? "protegem" o patrimônio de quem?

Entendemos que a responsabilidade atribuída ao Museu, de "Guardião da Musealidade", implica necessariamente na existência de regras. Por isso, acreditamos que, em um Museu Integral, a transversalidade das novas formas de diálogo entre o museu e a sociedade, por meio do Lazer Cultural, da Educação Não Formal e do Patrimônio Cultural, além de atender às três finalidades primas do museu (estudo, educação e lazer) e de contribuir no aprimoramento do alcance da função social museológica, também instrumentalizariam o 
indivíduo, despertando o consciente de seu conhecimento. Assim, o museu não precisaria se proteger "dele", pois "ele" o protegeria.

O uso não pressupõe destruição, assim como, trancar um objeto em uma reserva técnica de um museu não pressupõe preservação. Ao contrário, inúmeras experiências demonstram que protegemos o que conhecemos, o que nos é desconhecido não conta com a nossa devoção. E é a inexistência dela que levou ao fechamento de muitos museus nas últimas décadas, enterrando em suas paredes e destinando ao lixo, em alguns casos, um patrimônio deteriorado e desconhecido.

Entretanto, o uso que protege não é aquele proporcionado pela indústria cultural do lazer massificado e alienante que visa apenas o consumo, não é aquele que inclui o turista e afasta a comunidade local, nem aquele que convida a vizinhança e segrega as regiões periféricas. Não é aquele que acontece durante uma exposição temporária que atrai milhares de pessoas, mas que saem do museu apenas com uma foto e nenhuma experiência, também não é aquele cuja visita escolar não passe de um passeio desconexo com o currículo da escola e definitivamente não é aquele que ocorre durante um curso de formação, que ninguém compareceu.

O uso que protege é aquele que pressupõe o pertencimento. Assim, Carlan (2008) aponta que “os museus e o patrimônio, como instituições públicas, não podem ficar com as portas fechadas para a população. Devem guardar seus acervos, não escondê-lo”. Ele inclusive exemplifica que "os objetos arqueológicos encarcerados nas reservas técnicas devem ser analisados, estudados e apresentados ao público, acadêmico ou não. (CARLAN, 2008, p. 84, grifo nosso). Abrir o patrimônio de forma consciente não seria o seu fim, mas o ensejo para novas práticas.

O convite ao uso feito pelo diálogo por meio do lazer cultural lazer, estabelecido tanto para fins de entretenimento quanto para o desenvolvimento do próprio indivíduo, conduz à proteção pela instrumentalização do indivíduo proporcionada pelo diálogo por meio da educação não formal, o que instiga o pertencimento ao estabelecer o diálogo por meio do patrimônio cultural.

Não encontramos palavras melhores do que as de Antônio Cicero (1996 p. 337), em seu poema Guardar, para transmitir a nossa concepção de uso, proteção e pertencimento: 
Guardar uma coisa não é escondê-la ou trancá-la. Em cofre não se guarda coisa alguma. Em cofre perde-se a coisa à vista.

Guardar uma coisa é olhá-la, fitá-la, mirá-la por admirá-la, isto é, iluminá-la ou ser por ela iluminado.

Guardar uma coisa é vigiá-la, isto é, fazer vigília por ela, isto é, velar por ela, isto é, estar acordado por ela, isto é, estar por ela ou ser por ela.

Por isso melhor se guarda o vôo de um pássaro Do que um pássaro sem vôos [...]

Não podemos perpetuar modelos que levam a um museu que esconde ou tranca um patrimônio, tirando da vista da sociedade algo que lhe pertence. Devemos sim incentivar um modelo (não uma fórmula exata, mas uma essência) de um museu que ilumine a sociedade por meio do conhecimento, que, pelo pertencimento, a instigue como responsável pela sua vigília, que vele por ele, que se mantenha acordada por ele, que esteja e seja por ele.

Assim, nossa visita ao futuro no Capítulo 4 Paradigmas Museológicos Futuros: museus interativos, dinâmicos e presentes, possibilitou o cumprimento do objetivo específico desta pesquisa: apresentar a Instituição Museu contemporânea sob o prisma das novas formas de diálogo com a sociedade, trabalhando a ideia de que essa mudança na postura museológica aproxima o museu da sociedade, contribuindo para o aprimoramento do alcance de sua função social.

Durante a jornada paradigmática feita por esta pesquisa, levantamos muitos questionamentos e suscitamos algumas reflexões. Sem a pretensão de concluir verdades ou apontar modelos de soluções, esperamos ter despertado em nosso leitor a criticidade freireana, quiçá, ter contribuído para a sua instrumentalização a respeito da função social dos museus.

Reservo aqui um momento para justificar (propositalmente fora do texto central) a inspiração para a temática dos diálogos proposta no Capítulo 4. Mesmo não se tratando de um estudo de caso, acreditamos que seja importante e construtivo o compartilhamento das motivações pessoais dos pesquisadores. 
Esta pesquisadora, ao se deparar com a realidade do Museu Histórico e Cultural de Arraias MHCA, e diante da responsabilidade de contar a história e a cultura de um povo ao qual ela acabara de conhecer, preferiu, em um primeiro momento, calar-se, para não contar a história "errada", para não patrimonializar e usar os objetos "errados". Os museus são mundos particularmente complexos; como escolher o que ou quem expor sem favorecer, sem ignorar, sem tendenciar? Como proteger o patrimônio sem segregar, sem distinguir, sem privilegiar? Foi por incentivo da professora Valdirene Gomes dos Santos de Jesus, gestora do MHCA, que entendemos que a realidade precisa ser enfrentada, debatida e transformada quando necessário.

Precisamos da apreciação crítica para superar o nosso silêncio e resignação a condutas e regras que tiveram a sua função em paradigmas passados, mas que não mais se sustentam no paradigma contemporâneo e precisam urgentemente ser superadas em um paradigma futuro. Nosso silêncio somente cede lugar para os que falam e será que eles têm a mesma preocupação com a inclusão, a diversidade e a representatividade que nós temos? Lembrada de que eu não estava sozinha recebi ajuda daqueles que sabiam e vivenciavam naturalmente tudo aquilo que eu ainda me esforçava para aprender sobre a história e a cultura de Arraias, a minha contribuição foi apenas evidenciar a capacidade que eles tinham, e por meio da experimentação, do diálogo e da criticidade de Paulo Freire fomos todos instrumentalizados.

Mesmo não se tratando de um estudo de caso, esta experiência pessoal, valida também a motivação para esta dissertação ser desenvolvida dentro de um Programa de Pós-Graduação em Mudança Social e Participação Política. Acreditamos que o Museu é uma instituição provedora e incentivadora de mudanças sociais, sendo, ela própria, inúmeras vezes também o receptáculo dessas mudanças (como pudemos perceber em nossa trajetória paradigmática), tornando-se um farol para a sociedade.

O Museu é também uma instituição de Participação Política. Se nos três primeiros paradigmas os museus viviam envoltos por uma aura sagrada que evocava certa inocência, foi neste paradigma que compreendemos que, na verdade, eles sempre foram e sempre serão um local de disputas de poder, um local político. E é em meio a estas disputas que surgem inúmeras contradições que nos levam até a questionar a real existência de uma função social dos museus. O que nos leva a retomar a problemática dessa pesquisa; tendo em vista sua trajetória 
paradigmática desde sua origem e, seu posicionamento e conduta a partir do movimento da Nova Museologia, as instituições museais contemporâneas cumprem a sua função social?

Como instituição que é, vale relembrar que o Museu está sob a responsabilidade das pessoas, que em sua essência também são complexas e contraditórias, o que não justifica o não cumprimento de sua função social, mas evidência a urgência de debatermos sobre o seu aprimoramento bem como sobre caminhos para o seu alcance. O elo entre o uso, a proteção e o pertencimento por meio dos diálogos presume uma relação muito particular entre o humano, o espaço, o tempo e a memória - relação esta a qual Scheiner (2012, p. 18) denominou 'musealidade'. O que somente encontra caminhos, diante de tamanha complexidade, em um museu cuja razão de seu existir seja a sua função social, ou seja, em um Museu Integral.

Atribuímos, enfim, a responsabilidade pela mensagem final sobre o futuro dos museus ao poema que nos acompanhou durante todo o texto, auxiliando na condução das ideias. Longe da pretensão de apresentar um desfecho, apontamos que:

Uma nova situação o aguarda: o existir tradicional e a forma viva.

E o museu, sim! ele está vivo, sob a proteção de Mnemosyne e a inspiração das musas, aguardando ansiosamente por suas novas transformações.

Viva o museu! 


\section{REFERÊNCIAS BIBLIOGRÁFICAS ${ }^{42}$}

ALVES, Rubem. Filosofia da ciência: Introdução ao jogo e suas regras. São Paulo. Brasiliense, 1981.

ALVES, Vânia Maria Siqueira; REIS, Maria Amélia Gomes de Souza. Tecendo relações entre as reflexões de Paulo Freire e a Mesa Redonda de Santiago do Chile, 1972. Revista Eletrônica do Programa de Pós-Graduação em Museologia e Patrimônio - PPG-PMUS Unirio| MAST vol. 6 no. 1,2013

AULICINO, Madalena P. Lazer e a Escola Pública de Ensino Médio em Ermelino

Matarazzo, Revista Licere, Belo Horizonte, v.14, n.2, jun/2011.

BARRETO, Margarita. Cultura e Turismo: Discussões Contemporâneas. Campinas. Papirus, 2007.

BOSI, Ecléa. Memória e Sociedade: Lembrança de velhos. 2. ed. São Paulo, Queiroz/EDUSP, 1987.

BRAMANTE, Antonio C. Lazer: concepções e significados. Licere, n. 1, v. 1. (p. 37-43). Belo Horizonte. CELAR/UFMG, 1998.

BRUNO, Maria Cristina Oliveira. Museologia e Museus: os inevitáveis caminhos entrelaçados. Cadernos de sociomuseologia, n. 25, p. 5-20, 2006.

Museu e Museologia: Ideias e conceitos. Abordagens para um balanço necessário. Publicado em Workshop ICOFOM LAM. Rio de Janeiro, p. 1-7, 2008.

CAMARGO, Luiz Octávio de Lima. O que é lazer? São Paulo. Brasiliense, 1992.

Educação para o lazer. São Paulo. Moderna, 1998.

. Sociologia do lazer. IN ANSARAH, Marília Gomes dos Reis. Turismo: como aprender como ensinar, São Paulo, SENAC, 2001.

CÂNDIDO, Manuelina Maria Duarte. Conceitos e proposições presentes em Vagues: a antologia da Nova Museologia. Ciência \& Letras, Porto Alegre: FAPA .n. 31, p. 15-29, 2002.

CAPRA, Fritjof. A teia da vida: uma nova compreensão dos sistemas vivos. Tradução de Newton Roberval Eichemberg. São Paulo. Cultrix, 1996.

CARLAN. Claudio Umpierre. Museus e o Patrimônio Histórico: uma relação complexa. Revista HISTÓRIA. São Paulo, 27 (2), 2008.

\footnotetext{
${ }^{42}$ De acordo com a Associação Brasileira de Normas Técnicas. NBR 6023 (2002).
} 
CASTILHO, L. A nova onda das exposições! Artescétera, 2014. Disponível em: <https://webcache.googleusercontent.com/search?q=cache:et0Jh4ZYG0AJ:https://artescetera. com.br/2014/08/04/a-nova-onda-das-exposicoes/+\&cd=1\&hl=pt-BR\&ct=clnk\&gl=br>. Acesso em: out. 2018.

CASTRO, Ana Lúcia Siaines de. O Museu do sagrado ao segredo. Rio de Janeiro. Revan, 2009.

CERÁVOLO. Suely Moraes. "Em nome do céu, o que é museologia”? Perspectivas de museologia através de publicações. Revista do Museu de Arqueologia e etnologia. São Paulo, 2004.

CHOAY. Françoise. A alegoria do patrimônio. Tradução Luciano Vieira Machado, $6^{\circ}$ edição. São Paulo. Estação Liberdade, Ed. UNESP, 2017.

CÍCERO, Antônio. Guardar - Poemas escolhidos. Rio de Janeiro: Editora Record, 1996.

CURY, Marília Xavier. Exposição: concepção, montagem e avaliação. São Paulo. Maisanablume, 2008.

Museologia, novas tendências IN GRANATO M; SANTOS,C. P.;LOUREIRO M. L. N. M. (orgs.) Museu e Museologia: interfaces e perspectivas, Museu de Astronomia e ciências afins. Rio de Janeiro. MAST, 2009.

Novas perspectivas para a comunicação museolágica e os desafios da pesquisa de recepção em museus. Actas do I Seminário de Investigação em Museologia dos Países de Língua Portuguesa e Espanhola, Volume 1, pp. 269-279, 2010.

2014.

Museologia- Marcos referenciais. Cadernos do CEOM, ano 1, n. 21, p. 45-74,

Museologia e conhecimento, conhecimento museológico: uma perspectiva dentre muitas. Revista Museologia \& Interdisciplinaridade, vol. II, n5, 2014 b.

DE MASI, Domenico. Ócio Criativo. São Paulo. Sextante, 1997.

DESVALLÉES, André; MAIRESSE, François (Editores). Conceitos-chave de Museologia; Bruno Brulon Soares e Marília Xavier Cury, tradução e comentários. São Paulo: Comitê Brasileiro do Conselho Internacional de Museus. Pinacoteca do Estado de São Paulo: Secretaria de Estado da Cultura, 2013.

DIAS, Cleber A.G. Teorias do lazer e modernidade: Problemas e definições. Belo Horizonte: Revista Licere, v.12, n.2, jun./2009.

DUARTE, Alice. Nova Museologia: os pontapés de sida de uma abordagem ainda inovadora. Revista Museologia e Patrimônio, v. 6, n. 1, p.99-117, 2013.

DUARTE, Maria M. C. A gestão e o planejamento institucional nos currículos universitários de Museologia: estudo preliminar". In: Musear, Revista do Departamento de 
Museologia da Universidade Federal de Ouro Preto, ano 1, n. 1. Ouro Preto: UFOP, p. 51-60, jun/2012.

Cartas de navegação: planejamento museológico em mar revolto. Cadernos de Sociomuseologia. Lisboa: CEIED, v. 48, abril/2014. Disponível em: http://revistas.ulusofona.pt/index.php/cadernosociomuseologia/article/view/4628/3135. Acesso em: 03 mar. 2017.

DUMAZEDIER, Jofre: Sociologia Empírica do Lazer. São Paulo: Perspectiva/SESC, 1973. Lazer e Cultura Popular. São Paulo: Perspectiva, 2004.

IBRAM, Instituto Brasileiro de museus. Subsídios para a elaboração de planos museológicos, 2016.

ICOM- International Council of Museums - (2001). Estatuto aprovado pela 20 ${ }^{\mathbf{a}}$ Assembléia Geral. Espanha: julho de 2001. Disponível em: http://icom.museum/definition.html. Acesso em: 10 jan. 2017.

FIGURELLI, Gabriela Ramos. Articulações entre educação e museologia e suas contribuições para o desenvolvimento do ser humano. Revista Eletrônica do Programa de Pós-Graduação em Museologia e Patrimônio - PPG-PMUS Unirio, MAST - vol. 4 no 2, 2011.

FONSECA, J. J. S. Metodologia da pesquisa científica. Fortaleza. UEC, 2002.

FONSECA, Maria Cecília Londres. O patrimônio em processo: trajetória da política federal de preservação no Brasil. $2^{a}$ edição, Rio de Janeiro: Editora UFRJ; MINC- IPHAN, 2005.

FREIRE, Paulo. Educação como prática da liberdade. Rio de Janeiro, Paz e Terra, 2011.

GARCÍA-CANCLINI, N. Los usos sociales del patrimonio cultural. In: Encarnación, patrimonio etnológico. Nuevas perspectivas de estudio. España: Consejería de Cultura, Junta de Andalucía, 1999.

GIL, A. C. Como elaborar projetos de pesquisa. $4^{\text {a }}$ edição. São Paulo: Atlas, 2007

GIRALDY, Danièle; BOUILHET, Henri. O museu e a vida. Tradução Jeanne France Filliatre Ferreira da Silvia. Rio de Janeiro. Fundação Nacional Pró-menória, 1990.

GODBEY, G. Leisure in your life: an exploration. Pennsylvania. Venture Publishing, 3r ed. 1990.

GOMES, Denise Maria Cavalcanti. Turismo e Museus: Um Potencial a Explorar. IN: FUNARI, Pedro Paulo, PINSKY, Jaime (orgs.). Turismo e Patrimônio Cultural. São Paulo. Contexto, 2001.

GOMES, Christianne Luce (Org.). Dicionário crítico do lazer. Belo Horizonte: Autêntica Editora, 2004. 
GOMES, C. L; MELO, V.A. Lazer no Brasil: trajetória de estudos, possibilidades de pesquisa. Porto Alegre: Revista Movimento, v. 9, n. 1, p. 23-44, jan/abr 2003.

HEINICH, Nathalie O inventário: um patrimônio em vias de desartificação? PROA - Revista de Antropologia e Arte, v. 1, n. 5. Disponível em:

http://www.revistaproa.com.br/05/?page_id=12, 2013

HORKHEIMER, M. e ADORNO, T. W. Dialética do Esclarecimento: Fragmentos filosóficos. Trad. Guido Antonio de Almeida. Rio de Janeiro. Jorge Zahar, 1997.

JULIÃO, Letícia. Apontamentos sobre a história do museu. IN: Caderno de Diretrizes Museológicas. Brasília: MinC/Iphan/Departamento de Museus e Centros Culturais; Belo Horizonte: Secretaria de Estado da Cultura/Superintendência de Museus, 2006.

KRIPPENDORF, J. Sociologia do turismo: para uma compreensão do lazer e das viagens. São Paulo. Aleph, 2001.

KUHN, Thomas S. A estrutura das revoluções científicas. Tradução de Beatriz Vianna Boeira e Nelson Boeria. $5^{\circ}$. ed. São Paulo. Perspectiva, 1970.

A estrutura das revoluções científicas. São Paulo. Editora perspectiva, 2003.

MARCELLINO, Nelson Carvalho. Estudos do lazer: uma introdução. Campinas. Autores Associados, 2000.

MAY, Tim. Pesquisa Social: Questões, métodos e processos. Tradução Carlos Alberto Silveira Netto Soares. $3^{\circ}$ edição. Porto Alegre. Artmed, 2004.

MENSCH, Peter Van. O objeto de estudo da Museologia. Tradução: Débora Bolsanello e Vânia Dolores Estevam de Oliveira. Rio de Janeiro: UNI-RIO/UFGF, 1994.

MHCA, Museu Histórico Cultural de Arraias. Ficha temática, o que é acervo e coleção? MHCA Educativo. Arraias- Tocantins, 2018.

MORIN, Edgar. A indústria Cultural: Cultura de Massa no Século 20. $4^{\circ}$ ed. Rio de Janeiro. Forense Universitária, 1977.

Ciência com consciência. Rio de Janeiro. Bertrand, 2000.

POULOT, Dominique. Museu e Museologia. Belo Horizonte. Autêntica, 2013.

PRATS, L.. La mercatilización del patrimonio. PH Boletín del Instituto Andaluz del Patrimonio Histórico, no 58, mayo, pp. 72-80, 2006.

SANDELL, Richard. Social inclusion, the museum and the dynamics of sectorial change. Museum and Society, v. 1, n. 1, p. 45-62, 2003.

SANTOS, Boaventura de Souza. Um discurso sobre as ciências. Porto. Edições Afrontamento, 2006. 
SANTOS, Fausto Henrique dos. Metodologia aplicada em museus. São Paulo. Mackenzie, 2000.

SANTOS, Thiago da Silva; GERMANO, Marcelo Gomes. Educação formal, informal e não formal e os museus de ciências, 2015.

SCHEINER, Teresa Cristina. Repensando o Museu Integral: do conceito às práticas. Boletim do museu Paraense Emilio Goeldi. Ciências Humanas, v. 7, n. 1, p. 15-30, jan-abr/ 2012.

Reflexões sobre Museus, Turismo, Patrimônio e Sociedade. Revista

Iberoamericana de Turismo- RITUR, Penedo, Volume 7, Dossiê Número 3, p. 6-25, 2017.

SEMEDO, Alice. Formação em museologia: círculos e outras geometrias. Anais do Museu Paulista, v. 21, n. 1, p. 49-62, 2013.

SEVERINO, A. J. Metodologia do trabalho científico. São Paulo: Cortez, 2013.

SOUZA, Jessé. A elite do atraso: da escravidão à Lava Jato. Rio de Janeiro: Leya, 2017.

SOUZA, Tatiana R. Lazer e Turismo: reflexões sobre suas interfaces. Anais do VI Seminário de pesquisa em turismo no Mercosul: Saberes e fazeres do turismo: interfaces. Universidade de Caxias do Sul, 9 e 10 de Julho de 2010. Caxias do Sul, 2010.

SUANO, Marlene. O que é museu? São Paulo: Brasiliense, 1986.

TOMAZZONI, Edegar L. Dimensão cultural do turismo: uma proposta de análise. Fênix Revista de História e Estudos Culturais Julho/ Agosto/ Setembro de 2008 Vol. 5 Ano V no 3. Disponível em: www.revistafenix.pro.br, 2008.

UNESCO. International Standard Classification of Education - ISCED. Montreal: Quebec. Unesco: Institute for Statistics, 2011.

VARINE, Hugues de. O patrimônio cultural: a experiência internacional,1975.

As raízes do futuro: o patrimônio a serviço do desenvolvimento local. Trad. Maria de Lourdes Parreiras Horta. $1^{\circ}$ reimpressão. Porto Alegre. Medianiz, 2013.

VASCONCELlOS, Camilo de Mello. Turismo e Museus. São Paulo. Aleph, 2006.

ZANIRATO, Silvia Helena. Usos sociais do patrimônio cultural e natural. Patrimônio e Memória. Unesp- FCLAs - CEDAP v. 5, n.1, p. 137-152, out, 2009.

ZANIRATO, S. H. Patrimônio e identidade: retórica e desafios nos processos de ativação patrimonial. Rev. CPC, v.13, n.25, p.7-33, jan./set, 2018.

ZAVALA, Lauro. La educación y los museos en una cultura del espetáculo. Encuentro Nacional ICOM/CECA México: la educación dentro del museo, nuestra propia educación, 2001. 


\section{DOCUMENTOS CONSULTADOS}

\section{CÓDIGO DE ÉTICA PARA MUSEUS DO ICOM - 2009. Disponível em:}

http://www.mp.usp.br/sites/default/files/arquivosanexos/codigo_de_etica_do_icom.pdf

DECLARAÇÃO DE CARACAS. Disponível em: http://www.minom-portugal.org/docscaracas1992.pdf

DECLARAÇÃO DE QUEBEC. Disponível em: http://www.minom-portugal.org/docsquebec1974.pdf

DECLARAÇÃO DE SANTIAGO. Disponível em: http://www.minom-portugal.org/docssantiago1972.pdf

ESTATUTOS DO ICOM. Disponível em: http://icom.museum/ . http://icom.museum/theorganisation/icom-statutes/. Acesso em: 10 abr. 2017.

ISS- ICOFOM STUDY SERIES. Disponível em:

http://network.icom.museum/icofom/publications/our-publications/. Acesso em: 03/05/2017

UNESCO. Convenção para o patrimônio mundial, cultural e natural, ONU, 1972. 


\section{SITES CONSULTADOS}

IBRAM. Exposições brasileiras estão entre as 20 mais visitadas no mundo em 2014. Publicado em 07/04/2015. Disponível em: http://www.museus.gov.br/exposicoesbrasileiras-estao-entre-as-20-mais-visitadas-no-mundo-em-2014/. Acesso em: 06 de Março de 2019.

ICOFOM. Comitê Internacional para a Museologia. Disponível em: http://www.icom.org.br. Acesso nos anos de 2017, 2018 e 2019.

MENDES, Letícia. Exposições pop atraem visitantes que não frequentavam museus de SP. G1, 2014. Disponível em: http://g1.globo.com/pop-arte/noticia/2014/08/exposicoes-popatraem-visitantes-que-nao-frequentavam-museus-de-sp.html. Acesso em: 04 abril 2018.

MINISTÉRIO DO TURISMO. Museus estão entre os atrativos turísticos mais visitados no Brasil. Publicado em 27/01/2017. Disponível em:

http://www.turismo.gov.br/\%C3\%BAltimas-not\%C3\%ADcias/7464-museus-est\%C3\%A3oentre-os-atrativos-tur\%C3\% ADsticos-mais-visitados-no-brasil-3.html. Acesso em:

22/11/2018.

MINOM. Movimento Internacional para uma Nova Museologia. Disponível em: http://www.minom-portugal.org/docs.html. Acesso em: 16/10/2019.

MIS. Museu da Imagem e do Som. Disponível em: https://www.mis-sp.org.br. Acesso em 03/04/2019.

MUSEU DA PESSOA. Disponível em: http://www.museudapessoa.net/pt/home. Acesso em 08/04/2019.

Notas sobre a história dos museus. Disponível em: http://www.museus.art.br/historia.htm. Acesso em : 20 abr. 2016.

Notas sobre conceitos de museologia. Disponível em: www.revistamuseu.com.br. Acesso em 20 abr. 2016.

PINA, Pinacoteca de São Paulo. Disponível em: http://pinacoteca.org.br/. Acesso em 18/02/2019. 
Ana Paula Rosa Rodrigues

anapaularosa@usp.br

anapaularosarodrigues@yahoo.com.br 